\title{
LIEBIGS ANNALEN DER CHEMIE
}

HERAUSGEGEBEN VON DER

GESELLSCHAFT DEUTSCHER CHEMIKER

JAHRGANG $1984 \cdot$ HEFT $11 \cdot$ SEITE $1759-1882$

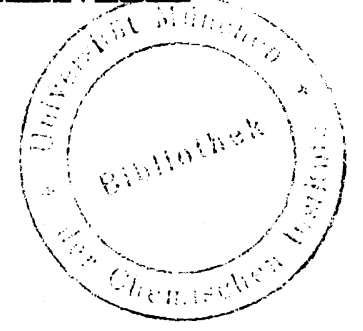




\section{Autorenregister}

Abass, A. Carbonyl and thiocarbonyl compounds: reac= tions of 4-chloroxanthione with diazoalkanes and compounds containing active hydrogen. 191

Abass, A. Reactions of 4-chloro-9H-xanthene-9-thione with tetrachloro-o-benzoquinone. 196

Abd El-Bary, H. Reactions with 2-methyl- and 2-sty= ryl-4-thiochromones. 186

Ackermann, K. Chemistry of reactive cations derived from sulfur dioxide analogs. X. Reaction with aromat= ic carbodiimides - synthesis of benzothiadiazines. 904

Aebi, J. D. Enantiomerically pure synthons from branched malates (correction). 407

Afza, N. Stereospecific syntheses of D-ossamine and D-tolyposamine. 636

Aldag, R. Crown ethers with triose and pentose struc $=$ tural units. 1036

Allgaier, H. Iturin AL: structure and derivatives of a peptidolipid with a high content of $\mathrm{C}_{16}$-iturinic acids. 854

Anke, T. Antibiotics from Basidiomycetes, XIX. Nae= matolin and naematolone, two caryophyllane deriva $=$ tives from cultures of Hypholoma species (Agaricales) 1332

Anke, T. Antibiotics from basidiomycetes, XX. Synthe= sis of strobilurin A and revision of the stereochemistry of natural strobilurins. 1616

Antus, S. An attempted synthesis of polystachin. 1068

Aoyagi, M. Multistep reversible redox systems, XXXIX. Isomeric biazulenyls: UV/VIS spectroscopy, voltam= metry, and HMO energies. 1952

Arndt, F. Syntheses of thiazolo- and $[1,3]$ thiazino[1,2, 4]triazinones. 1302

Aumueller, A. Multistep, reversible redox systems. XXXVI. $11,11,12,12$-Tetracyano-9,10-anthraquinodi= methan (TCNAQ) and its derivatives: synthesis and redox properties. 618

Bach, T. C. Syntheses with nucleic acid constituents, X. Mass spectrometry of nucleotides, VII. Synthesis of deoxyoligonucleotide linker fragments for genetic engineering using improved preparative and analytical techniques. 835

Backens, S. Antibiotics from Basidiomycetes, XIX Naematolin and naematolone, two caryophyllane derivatives from cultures of Hypholoma species (Agar= icales). 1332

Banerjee, S. K. Lactonic constituents of Angelica glau= ca. 888

Barlos, K. Application of N-trityl amino acid 1-benzo= triazolyl esters in peptide synthesis. 1308

Bauer, H. Kinetics, catalysis, and mechanism of the secondary reaction in the final phase of the formose reaction. 623

Baur, R. Pteridines, LXXIV. Acylations of lumazines by radical nucleophilic substitution. 1798

Begtrup, M. Annulated 1,2,3-triazoles, I. Synthesis of 8-azapurin-6-ones and 8-azapurin-6-imines from ethyl 5-(acetylamino)-1,2,3-triazole-4-carboxylates. 1848

Bellinger, O. Chemistry of dimethyl $(1 \alpha, 2 \beta, 5 \beta, 6 \alpha, 7 \beta,=$ $8 \beta)-3,4$-dioxotricyclo[4.2.1.02,5]nonane-7,8-dicarboxy $=$ late. 1109

Bellinger, 0. The behavior of $(1 \alpha, 2 \alpha, 5 \alpha, 6 \alpha)-3,4$-bis(tri $=$ methylsiloxy)tricyclo[4.2.1.02,5]nona-3,7-diene on treatment with oxidative reagents. 1778

Bellmann, P. Synthesis of 2-acyl-3-aminofurans by Thorpe cyclization. 1702

Benz, G. Albomycins, I. Enzymic cleavage of the deferri form of albomycins $\delta_{1}$ and $\delta_{2} .1399$

Benz, G. Albomycins, II. Absolute configuration of the deferri form of the albomycins. 1408

Benz, G. Albomycins, III. Synthesis of $\mathrm{N}^{5}$-acetyl-N5-= hydroxy-L-ornithine from $\mathrm{L}-$ glutamic acid. 1424

Benz, G. Albomycins, IV. Isolation and total synthesis

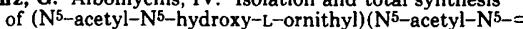
hydroxy-L-ornithyl)-N5-acetyl-N5-hydroxy-L-ornith= ine. 1434

Liebigs Ann. Chem. 1984
Berneth, H. Multistep reversible redox systems. $\mathrm{XXXV}$. Voltammetry of vinylogous polyenes with cross-conjugated end groups and UV/VIS spectrosco $=$ py of their radical anions and cations. 354

Bestmann, H. J. Retinoids and carotenoids, II. Synthe= sis of (13Z)-retinoic acids. 1740

Bieber, $\mathbf{M}$. Iodination of monosaccharide derivatives with iodotrimethylsilane. 1052

Bignardi, G. Constituents of Cupuliferae, 8. A novel, highly-acylated astragalin from Quercus ilex L. 1864

Binh Vu A simple method for the preparation of 2-aryl= benzofurans and the synthesis of moracin $A$ and $B$. 734

Birkofer, L. Organosilicon compounds. LXXXIV. $\beta$-Lactams. III. $\beta$-Lactams via $\mathrm{N}$-silylcarbodiimides 1193

Blount, J. F. Reactions of 1,4-pentadien-3-ones, 22. Synthesis and structure of the epimers of 3,5-diaryl-= 4-hydroxy-1,4-thiazinane 1,1-dioxides. 1013

Boberg, F. Nef reaction. VI. 4,5-Dihydro $-5-($ methyle $=$ neamino)-3-furancarboxylates. 223

Boberg, F. Heterocycles from $\alpha$-nitroolefins, VII. 4,5-= Dihydro-2-methyl-5-(methyleneamino)-3-furancarb $=$ oxylates from $\alpha$-nitroolefins, acetoacetates, and com $=$ pounds with an active methylene group. 911

Boecker, $\mathbf{R}$. Origin of 3,6-epoxyalkanedioic acids in human urine. 1513

Boehm, H. Synthesis of stereoisomeric 3,4-dihydrobili= rubinic acid derivatives as synthons for bile pigments 1441

Bohlmann, F. New sesquiterpene lactones and rosane derivatives from Trichogonia species. 162

Bohlmann, F. New spirosequiterpene lactones, germa= cranolides, and eudesmanolides from Wunderlichia mirabilis. 228

Bohlmann, F. New germacranolides, heliangolides, and elemanolides from Cronquistianthus chachapoyensis. 240

Bohlmann, F. Epoxycannabinolide and diterpenes with a new carbon skeleton from Villanova titicaensis. 250

Bohlmann, F. Heliangolides and trachylobane and villanovane derivatives from Viguiera species. 495

Boblmann, F. Pseudoguaianolides and other sesquiterp= enes from Monactis macbridei. 503

Bohlmann, F. Synthesis of rac-4 $\beta$-hydroxyobovata $=$ chromene. 1382

Bohlmann, F. Synthesis of further eremophilane deriva $=$ tives. 1785

Boidol, W. Syntheses with nucleic acid constituents, $X$ Mass spectrometry of nucleotides, VII. Synthesis of deoxyoligonucleotide linker fragments for genetic engineering using improved preparative and analytical techniques. 835

Born, L. Albomycins, II. Absolute configuration of the deferri form of the albomycins. 1408

Boross, F. An attempted synthesis of polystachin. 1068

Bosch, $\mathbf{R}$. Conformation of Boc-L-Ala-Aib-L-Ala-OMe in the crystal and in solution. 1117

Bosch, R. Configuration and conformation of the nu= cleoside residues of the nikkomycins. 1216

Botulinski, A. Metal complexes with tetrapyrrole li= gands, XXXV. Synthesis of further more or less sterically hindered 5,15-dialkyloctaethylporphodimet = henes by reductive alkylation of octaethylporphyrina = tozinc. 1259

Braeuner, H. J. Orthoamides. XI. Preparation of $1,1,2$, 3,3 -penta-substituted and $1,1,2,2,3,3$-hexa-substituted guanidinium salts and $1,1,2,3,3$-pentaalkylguanidines. 108

Brewer, C. F. Reactions of enolic sugar derivatives, XVI. Synthesis of a diastereotopic proton probe [(Z)-3,7-anhydro-1,2-dideoxy-D-gluco-oct-2-enitol] for $\alpha$ - and $\beta-D$-glucosidases. 1078

Brewer, C. F. Reactions of enolic sugar derivatives, XVI. Synthesis of a diastereotopic proton probe [(Z)-3,7-anhydro-1,2-dideoxy-D-gluco-oct-2-enitol] for $\alpha-$ and $\beta-\mathrm{D}$ glucosylases (correction). 1626

Brieden, M. Albomycins, II. Absolute configuration of the deferri form of the albomycins. 1408 
Brockmann, R. Enehydrazines, 37. Synthesis of a pyrazole analog of 7-aminomitosene. 1711

Buchler, J. W. Metal complexes with tetrapyrrole ligands, XXXV. Synthesis of further more or less sterically hindered 5,15-dialkyloctaethylporphodimet= henes by reductive alkylation of octaethylporphyrina = tozinc. 1259

Buenzel, M. Metalloporphyrins in polymeric matrixes, micelles, and vesicles, V. 5-(1'-Methyl-4,4'-bipyridi= nium-1-yl)octaethylporphyrin dichloride, a meso-viol= ogenporphyrinate. 426

Burger, K. $4 \mathrm{H}-1,3,5-0 x a d i a z i n e s$ and $4 \mathrm{H}-1,3,5-$ thia $=$ diazines from cyanamides and perhalo ketones and thio ketones. 982

Burger, K. Trifluoromethyl-substituted pyrimidines from enamines and trifluoroacetonitrile. 991

Busam, L. Macrocyclic trichothecenes from Baccharis coridifolia, I. Miotoxin B and C, two new macrocyclic trichothecenes from Baccharis coridifolia DC. 1746

Bussmann, W. Anomers of tubercidin derivatives with 2-methylthio and $\mathrm{N}^{4}-\left(\Delta^{2}\right.$-isopentenyl) residues. 1972

Calderon, 0 . Synthesis of 4-aminocinnolines from (arylhydrazono)(cyano)acetic acid derivatives. 1390

Caplar, V. Cycloarenes, a new class of aromatic com = pounds. III. Studies towards the synthesis of cyclo $=$ [d.e.d.e.e.d.e.d.e.e.]decakisbenzene (correction). 408

Carlsson, G. Configuration and conformation of the nucleoside residues of the nikkomycins. 1216

Castro, V. Heliangolides and trachylobane and villano $=$ vane derivatives from Viguiera species. 495

Christ, J. 1,5-Dimethylbicyclo[3.3.0]octane-2,6-dione and 1,5-dimethylbicyclo[3.3.0]octa-3,7-diene-2,6-= dione. Basic synthons for substituted semibullval = enes. 1180

Chylinska, B. Reactions of organic anions. 113. Vicari= ous nucleophilic substitution of hydrogen in nitropyri= dines by $\alpha$-chloroalkyl phenyl sulfone carbanions. 8

Cichy, M. New constituents of Levisticum officinale Koch. 397

Dann, O. Syntheses of antimicrobial biscationic 2-= (phenoxyphenyl)indoles and -1-benzofurans. 409

Daub, J. Selective reactions of hydroazulenes: chiral norcarane derivatives by the reaction of a dihydroaz = ulene with singlet oxygen. 773

Decker, K. Feodor Lynen. 1911-1979. Issue 9.

Deger, S. Synthesis and structure of cyano(dihydrodi= benzo[b,i] $[1,4,8,11]$ tetraazacyclotetradecinato $)$ cobalt $=$ (III). 1791

Dickerhof, $\mathbf{K}$. Occurrence of hydrogen transfer, 73 Reduction of prochiral alkyl (aryl) ketones to carbi= nols and pinacols with alkali metal amalgams. 1240

Diederich, $\mathbf{F}$. Cycloarenes, a new class of aromatic compounds. III. Studies towards the synthesis of cyclo[d.e.d.e.e.d.e.d.e.e.]decakisbenzene (correction). 408

Dittel, W. Polyhydroxyamino compounds via diene synthesis with nitroso compounds. IX. trans-6-Azi= do-1,3-cyclohexadien-5-ol as educt for the synthesis of condurodiamine and streptamine isomers. 203

Driller, H. 7- $\beta$-D-Arabinofuranosyl $)-2,4-$ dichloro-7H- $=$ pyrrolo[2,3-d]pyrimidine - synthesis, selective dis $=$ placement of halogen, and effect of glyconic protecting groups on the reactivity of the aglycon. 722

Duddeck, H. Synthesis and carbon-13 NMR spectro= scopic studies of bridgehead-substituted endo-bicy= clo[3.3.1]nonan-3-ols and oxaadamantanes. 1981

Eckstein, Z. Chemistry of hydroxamic acids. 10. A convenient rearrangement of 4-quinolinecarbohydrox $=$ amic acid. 395

Eiden, F. Benzothiazoles by carbon-carbon cleavage of $\alpha-[(2-$ nitrophenyl)thio] ketones. 1100

Eiden, F. Pyrans, 100. 5,6-Dihydro-2H-pyran-3(4H)-= one as a synthon for pyran-annulated heterocyclic compounds. 1759

El-Moghazy Aly, S. M. Studies of the chemistry of natural organic materials. 89 . Halogenation reactions of 1,3-dihydroxy-10-methyl-9 $(10 \mathrm{H})$-acridinone and its ethers - a simple regiospecific synthesis of acrony= cine. 31

El-Sakka, I. Carbonyl and thiocarbonyl compounds: reactions of 4-chloroxanthione with diazoalkanes and compounds containing active hydrogen. 191

El-Sakka, I. Reactions of 4-chloro-9H-xanthene-9-= thione with tetrachloro-o-benzoquinone. 196

Ermann, P. Retinoids and carotenoids, II. Synthesis of (13Z)-retinoic acids. 1740
Falsone, G. Constituents of Boraginaceae, 7. Anchuso= side -8 and -9 : two new triterpene saponins from Anchuse officinalis L. 1869

Ferwanah, A. R. Syntheses with aliphatic dialdehydes, XXXVIII. Synthesis and properties of cycloalkylmal= onaldehydes. 649

Feustel, M. Polyynes. 3. Synthesis of (1,3-alkadiynyl $)=$ amines. 586

Filipovic-Marinic, N. Contributions to the chemistry of tetraketones. II. Reaction of 3,4-dibenzoyl-2,5-= hexanedione with hydroxylamine. 199

Flitsch, $\mathbf{W}$. Contribution to the synthesis of 8-azapros= tanoids: reaction of succinimides with (benzoylme= thylene)triphenylphosphorane. 1878

Formacek, V. Reactions with isocyanides. Synthesis of dark-blue dyes from 1,4-quinones and aryl isocyan= ides. 1003

Formacek, V. Structure of the 1:1 adducts of aryl iso $=$ cyanides to 4-benzoyl-5-phenylfuran-2,3-dione and their products with nucleophiles. Novel rearrange $=$ ments of 5,5-disubstituted 4-methylenefuran-2,3-= diones. 1137

Franke, $\mathbf{W}$. Syntheses of thiazolo- and $[1,3]$ thiazino[1,2,4]= triazinones. 1302

Frischkorn, H. Naphthylenedi(heteroarenes), III. Syn= thesis and spectroscopic behavior of 2,2'-naphthylene= dibenzazoles. 1129

Fuhrhop, J. H. Metalloporphyrins in polymeric matrix = es, micelles, and vesicles, V. 5-(1'-Methyl-4,4'-bipy $=$ ridinium-1-yl)octaethylporphyrin dichloride, a meso-viologenporphyrinate. 426

Fuhrhop, J. H. Metalloporphyrins in polymeric matric = es, micelles, and vesicles. VI. Hydrophobic and hydro $=$ philic derivatives of 3,8-diformyldeuteroporphyrin dimethyl ester and their interaction with vesicles. 1057

Fuhrhop, J. H. Synthesis and reactivity of $13^{1}, 13^{2}, 17^{1}=$ $17^{2}$-tetradehydrodeuteroporphyrin. 1386

Fuhrhop, J. H. Chelating vesicles made from $\mathrm{N}, \mathrm{N}-\mathrm{di}=$ hexadecyl-1,2-ethanediamine-N', $N^{\prime}$-diacetic acid 1634

Fukazawa, Y. Multistep reversible redox systems, XXXIX. Isomeric biazulenyls: UV/VIS spectrosco $=$ py, voltammetry, and HMO energies. 1952

Garburg, K. H. Heterocycles from $\alpha$-nitroolefins, VII 4,5-Dihydro-2-methyl-5-(methyleneamino)-3-furan = carboxylates from $\alpha$-nitroolefins, acetoacetates, and compounds with an active methylene group. 911

Garming, A. Nef reaction. VI. 4,5-Dihydro-5-(methy= leneamino)-3-furancarboxylates. 223

Geffken, D. 1,2-Oxazetidin-3-ones from (2-thienyl)gly= colohydroxamic acids and 1,1'-carbonyldiimidazole. 894

Gerke, T. New sesquiterpene lactones and rosane deri= vatives from Trichogonia species. 162

Gewald, K. Synthesis of 4-aminocinnolines from (aryl= hydrazono)(cyano)acetic acid derivatives. 1390

Gewald, K. Synthesis of 2-acyl-3-aminofurans by Thorpe cyclization. 1702

Gnichtel, H. Cycloaddition with unsaturated carbohyd = rates, III. The stereochemistry of the Diels-Alder reaction with hex-2-enopyranoside and hex-2-enopy = ranosid-4-uloses. 1531

Gnichtel, H. Chemistry of amino oximes, XVIII. The cyclocondensation of $(\mathrm{E})-\beta-($ chloroacetylamino)pro $=$ piophenone oxime derivatives. 1696

Goerlich, K. J. Heterocycles from $\alpha$-nitroolefins, VII. 4,5-Dihydro-2-methyl-5-(methyleneamino)-3-furan = carboxylates from $\alpha$-nitroolefins, acetoacetates, and compounds with an active methylene group. 911

Gora, J. Synthesis of new tetrahydrofuran and tetrahy= dropyran derivatives from $\alpha$-pinene and 3-carene. 1860

Gottschall, K. Synthesis of stereoisomeric 3,4-dihydro= bilirubinic acid derivatives as synthons for bile pig: ments. 1441

Gottschall, K. Synthesis of rac-stercobilin IX $\alpha$ with the configuration of the natural product and of some urobilins, half-stercobilins, and stercobilins with unequivocal constitution and configuration. 1454

Graser, F. Crystal structure and color of perylene-3,4:9, = 10-bis(dicarboximide) pigments, 2 . 483

Graumann, J. Ring-chain isomerism of N-(1-carboxyal= kyl)nitrones. I. C-Aryl-N-(1-carboxylalkyl)nitrones. 1545 
Griessmeier, H. Syntheses of antimicrobial biscationic 2-(phenoxyphenyl)indoles and -1-benzofurans, 409

Grosser, R. Albomycins, II. Absolute configuration of the deferri form of the albomycins. 1408

Grundler, G. Glycosyl imidates, 13. Application of the trichloroacetimidate procedure to 2-azidoglucose and 2-azidogalactose derivatives. 1826

Guendel, W. H. Studies of quaternary pyridinium salts. XVI. Note on cyclization reactions with salts of amides of nicotinoylamino acids. 612

Guenther, H. J. Synthesis of 4-penten-4-olides $(\gamma-\mathrm{me}=$ thylene- $\gamma$-butyrolactones) via 4-pentenoic acids. 15

Gumprecht, C. Cycloaddition with unsaturated carboh= ydrates, III. The stereochemistry of the Diels-Alder reaction with hex-2-enopyranoside and hex-2-enopy= ranosid-4-uloses. 1531

Guntrum, E. Synthesis of 4-penten-4-olides ( $\gamma$-methyl= ene- $\gamma$-butyrolactones) via 4-pentenoic acids. 15

Gupta, B. D. Lactonic constituents of Angelica glauca. 888

Habermehl, G. G. Macrocyclic trichothecenes from Baccharis coridifolia, I. Miotoxin B and C, two new macrocyclic trichothecenes from Baccharis coridifolia DC. 1746

Haedicke, E. Crystal structure and color of perylene-3, 4:9,10-bis(dicarboximide) pigments, 2. 483

Haefelinger, G. Syntheses of mesityl-substituted azul= enes. 1605

Hagen, H. Orthoamides. XI. Preparation of 1,1,2,3,3-= penta-substituted and 1,1,2,2,3,3-hexa-substituted guanidinium salts and 1,1,2,3,3-pentaalkylguanidines. 108

Hagenbruch, B. Multistep reversible redox systems. XXXIV. Polyenes as four-step redox systems: synthe= sis and spectroscopy. 340

Hagenbruch, B. Multistep reversible redox systems. XXXV. Voltammetry of vinylogous polyenes with cross-conjugated end groups and UV/VIS spectrosco= py of their radical anions and cations. 354

Hagenmaier, $\mathbf{H}$. Configuration and conformation of the nucleoside residues of the nikkomycins. 1216

Haimova, M. Reactions of glutaconic and homophthalic anhydrides with imidates, imidoyl chlorides, and 1-chloroisoquinoline. 389

Hain, U. Synthesis of 4-aminocinnolines from (arylhy= drazono) (cyano)acetic acid derivatives. 1390

Hain, W. A contribution to the structural assignment of positional isomers of bis-galacto and bis-manno crown ethers. 1046

Hammann, H. Synthesis of 1,2,4-triazines. XI. Synthe= sis and reactions of 6-amino-1,2,4-triazin-5-ones and 6-amino-1,2,4-triazine-5-thiones. 283

Hanack, M. Synthesis and structure of cyano(dihydrodi= benzo[b,i] $[1,4,8,11]$ tetraazacyclotetradecinato $)$ cobalt $=$ (III). 1791

Hanefeld, W. Studies of 1,3-thiazines, 24. $\alpha$-Carbamoyl sulfoxides and sulfones, 1. 5,6-Dihydro-2H-1,3-thiaz= ine-2,4(3H)-dione 1-oxides and 1,1-dioxides, novel cyclic $\alpha$-carbamoyl sulfoxides and sulfones. 1627

Hanke, M. Multistep reversible redox systems, XXXIX. Isomeric biazulenyls: UV/VIS spectroscopy, voltam= metry, and HMO energies. 1952

Harsch, G. Kinetics, catalysis, and mechanism of the secondary reaction in the final phase of the formose reaction. 623

Hartke, $\mathbf{K}$. Boron complexes of malonamides and malo= namidines. 370

Hartke, K. Preparation of sulfonioindenides. 552

Hatjiissaak, A. Chemistry of reactive cations derived from sulfur dioxide analogs. X. Reaction with aromat ic carbodiimides - synthesis of benzothiadiazines. 904

Haug, E. Orthoamides. XI. Preparation of 1,1,2,3,3-pen= ta-substituted and 1,1,2,2,3,3-hexa-substituted guanidinium salts and 1,1,2,3,3-pentaalkylguanidines. 108

Haupt, H. J. Enehydrazines, 37. Synthesis of a pyrazole analog of 7-aminomitosene. 1711

Hayauchi, Y. Synthons of oligosaccharides, I.II. Syn= thesis of disaccharides from 3-deoxy-D-manno-2-oc= tulosonic acid (KDO) and D-glucosamine. 1270

Hayauchi, Y. Synthons of oligosaccharides, LIII. Syn= thesis of trisaccharides containing 3-deoxy-D-man = no-2-octulosonic acid (KDO). 1288

Hehre, E. J. Reactions of enolic sugar derivatives, XVI. Synthesis of a diastereotopic proton probe $[(\mathrm{Z})-3,7-=$ anhydro-1,2-dideoxy-D-gluco-oct-2-enitoll for $\alpha$ and $\beta-D-$ glucosidases. 1078
Hehre, E. J. Reactions of enolic sugar derivatives, XVI. Synthesis of a diastereotopic proton probe [(Z)-3,7-= anhydro-1,2-dideoxy-D-gluco-oct-2-enitol] for $\alpha$ and $\beta-D$ glucosylases (correction). 1626

Hein, F. Trifluoromethyl-substituted pyrimidines from enamines and trifluoroacetonitrile. 991

Helbig, W. Stereoselective synthesis of alcohols, XVII. Stereoselective synthesis of optically active $\alpha$-multis $=$ triatin, an attractant of the smaller European elm bark beetle, Scolytus multistriatus. 1165

Helbig, W. Stereoselective synthesis of alcohols, XVIII. Synthesis of $(3 S, 4 S)-4-$ methyl-3-heptanol and of $(5 \mathrm{~S}, 6 \mathrm{~S})$-anhydroserricornin. 1170

Henn, L. Cycloadditions, III. Reactions of ynamines with silylketenes. 1358

Hettinger, $\mathbf{P}$. Synthesis of the first leaf movement factor from Mimosa pudica L. 1230

Hiller, W. Synthesis and structure of cyano(dihydrodi= benzo[b,i] $[1,4,8,11]$ tetraazacyclotetradecinato $)$ cobalt = (III). 1791

Himbert, G. Aminoethynyl metalations. 13. Synthesis and reactions of 3-aminopropiolamidines. 85

Himbert, G. Polyynes. 3. Synthesis of $(1,3$-alkadiynyl $)=$ amines. 586

Himbert, G. Cycloadditions, III. Reactions of ynamines with silylketenes. 1358

Hirte, $\mathbf{K}$. Chemistry of amino oximes, XVIII. The cyclocondensation of $(E)-\beta-($ chloroacetylamino)pro $=$ piophenone oxime derivatives. 1696

Hissmann, E. The $\left(2^{\prime} \rightarrow 5^{\prime}\right)$ - and $\left(3^{\prime} \rightarrow 5^{\prime}\right)$-tubercidylyl tubercidins - synthesis via phosphite triester and studies of secondary structure. 692

Hoefle, G. Antibiotics from gliding bacteria. XVIII. The absolute configuration of myxalamide $\mathrm{A}$ and $\mathrm{B}$ 78

Hoefle, G. New constituents of Levisticum officinale Koch. 397

Hoefle, G. Lactonic constituents of Angelica glauca. 888

Hoefle, G. Antibiotics from gliding bacteria, XXII Biosynthesis of myxopyronin A, an antibiotic from Myxococcus fulvus, strain Mx f50. 1088

Hoefle, G. Antibiotics from gliding bacteria, XXIII. Stigmatellin A and B - two novel antibiotics from Stigmatella aurantiaca (Myxobacterales). 1883

Hoelzel, C. Piperine - an example of an individually different (polymorphic) metabolism of an omnipresent nutritional component. 1319

Hoffmann, E. H. Dehydrogenation reactions with gallic acid esters. 929

Hoffmann, R. Boron complexes of malonamides and malonamidines. 370

Hoffmann, R. W. Stereoselective synthesis of alcohols, XVIII. Synthesis of (3S,4S)-4-methyl-3-heptanol and of $(5 \mathrm{~S}, 6 \mathrm{~S})$-anhydroserricornin. 1170

Hofmann, $K$. Sulfosilylation of carbonyl compounds and trimethylsilyl enol ethers with trimethylsilyl chlorosulfonate. 39

Hollmann, J. Synthesis and conformational analysis of some 5'-homoadenosine derivatives. 98

Hoppe, I. Synthesis and biological activities of the antibiotic B 371 and its analogs. 600

Hoppe, I. Synthesis with $\alpha$-metalated isocyanides. LIII. Synthesis of methyl 2,3-epoxy-2-isocyanoalkanoates. 608

Horner, L. Occurrence of hydrogen transfer, 73. Reduc $=$ tion of prochiral alkyl (aryl) ketones to carbinols and pinacols with alkali metal amalgams. 1240

Hosmane, R. S. An efficient, one-step synthesis of 2-imidazolin-4(5)-one. 831

Huber, W. Chemistry and stereochemistry of iridoids, IV. Synthesis and $\mathrm{x}$-ray structure analysis of $15-\mathrm{me}=$ thyl-12-epi-prostaglandin $\mathrm{F}_{2 \beta}$. 761

Huber-Patz, U. Chemistry and stereochemistry of iridoids, IV. Synthesis and $\mathrm{x}$-ray structure analysis of 15-methyl-12-epi-prostaglandin $\mathrm{F}_{2 \beta} .761$

Huenig, S. Multistep reversible redox systems. XXXIV. Polyenes as four-step redox systems: synthesis and spectroscopy. 340

Huenig, S. Multistep reversible redox systems. XXXV. Voltammetry of vinylogous polyenes with cross-conju= gated end groups and UV/VIS spectroscopy of their radical anions and cations. 354

Huenig, S. Multistep, reversible redox systems. XXXVI. 11,11,12,12-Tetracyano-9,10-anthraquinodi= methan (TCNAQ) and its derivatives: synthesis and redox properties. 618 
Huenig, S. Multistep reversible redox systems, XXXVII. Biazulenyls and $\omega, \omega^{\prime}$-diazulenylpolyenes: syntheses and spectroscopic properties. 1905

Huenig, S. Multistep reversible redox systems, XXXVI= II. Biazulenyls and $\omega, \omega$-diazulenylpolyenes: reactions with protic acids, nucleophiles, and reducing and oxidizing agents. 1936

Huenig, S. Multistep reversible redox systems, XXXIX Isomeric biazulenyls: UV/VIS spectroscopy, voltam = metry, and HMO energies. 1952

Huenig, S. Multistep reversible redox systems, XL. $\omega, \omega^{\prime}$-Biazulenyl polyenes: voltammetry and $\mathrm{HMO}$ energies. 1959

Hunds, A. Compounds with Urotropin structure, LX. Orthooxalic and orthocarbonic acid derivatives with adamantane structure. 1577

Hunkler, D. Reactions of 1,4-pentadien-3-ones, 22. Synthesis and structure of the epimers of 3,5-diaryl-= 4-hydroxy-1,4-thiazinane 1,1-dioxides. 1013

Huth, A. 7-Aroyl-1H,7H-s-triazolo[1,2-a]-s-triazole-1, = $3(2 \mathrm{H})$-diones, a new class of compounds from 5-phe $=$ nyloxazoles and 4-phenyl-4H-1,2,4-triazole-3,5-= dione. 641

Ibis, C. Thio-substituted butynes and butadienes from polychlorobutenes and thiols. 1873

Ipaktschi, J. Reaction of diphenylcyclopropenone with allylidenetriphenylphosphoranes. 1989

Irngartinger, $\mathbf{H}$. Chemistry and stereochemistry of iridoids, IV. Synthesis and $\mathrm{x}$-ray structure analysis of 15-methyl-12-epi-prostaglandin $F_{2 \beta} .761$

Irschik, H. Antibiotics from gliding bacteria, XXII. Biosynthesis of myxopyronin A, an antibiotic from Myxococcus fulvus, strain Mx f50. 1088

Ito, S. Multistep reversible redox systems, XXXIX. Isomeric biazulenyls: UV/VIS spectroscopy, voltam = metry, and HMO energies. 1952

Jaeger, V. Synthesis of 4-penten-4-olides ( $\gamma$-methyl= ene- $\gamma$-butyrolactones) via 4-pentenoic acids. 15

Jaensch, H. J. Synthesis of 2-acyl-3-aminofurans by Thorpe cyclization. 1702

Jakupovic, J. New sesquiterpene lactones and rosane derivatives from Trichogonia species. 162

Jakupovic, J. New spirosequiterpene lactones, germa= cranolides, and eudesmanolides from Wunderlichis mirabilis. 228

Jakupovic, J. Heliangolides and trachylobane and villanovane derivatives from Viguiera species. 495

Jansen, R. Antibiotics from gliding bacteria. XVIII. The absolute configuration of myxalamide $A$ and $B$. 78

Jermann, F. Contribution to the synthesis of 8-azapros= tanoids: reaction of succinimides with (benzoylme $=$ thylene)triphenylphosphorane. 1878

Jung, G. Iturin $A_{L}$ : structure and derivatives of a pepti= dolipid with a high content of $\mathrm{C}_{16}$-iturinic acids. 854

Jung, G. Conformation of Boc-L-Ala-Aib-L-Ala-OMe in the crystal and in solution. 1117

Jutz, C. Multistep reversible redox systems, XXXIX. Isomeric biazulenyls: UV/VIS spectroscopy, voltam = metry, and HMO energies. 1952

Kajtar-Peredy, M. An attempted synthesis of polysta= chin. 1068

Kantlehner, W. Orthoamides. XI. Preparation of $1,1,2,=$ 3,3-penta-substituted and 1,1,2,2,3,3-hexa-substituted guanidinium salts and 1,1,2,3,3-pentaalkylguanidines. 108

Kapassakalidis, J. J. Orthoamides. XI. Preparation of $1,1,2,3,3$-penta-substituted and $1,1,2,2,3,3$-hexa-sub= stituted guanidinium salts and $1,1,2,3,3$-pentaalkyl= guanidines. 108

Kappel, M. Pteridines, LXXV. Synthesis and proper= ties of biopterin and biopterin analogs. 1815

Katsurada, M. Pheromone synthesis. LXIV. Synthesis of the enantiomers of 2-methyl-1,7-dioxaspiro[5.6]do= decane, a component of the volatile secretion from the mandibular glands of Andrena haemorrhoa F. 157

Kawasaki, T. Biologically active glycosides from Aster= oidea. VII. Steroid oligoglycosides from the starfish Luidia maculata Mueller et Troschel. 2. The struc= tures of two new oligoglycoside sulfates. 296

Kern, W. Tetrahydrofuran acids - a new class of com $=$ pounds in human metabolism. 1504

Kettler, R. Chemistry of nitrosamines, IV. Syntheses of $\alpha-\mathrm{C}$-functionalized $\mathrm{N}$-nitrosodialkylamines: ester and ethers of $1-[($ alkyl)(nitroso)amino]alcohols. 1468
King, R. M. New sesquiterpene lactones and rosane derivatives from Trichogonia species. 162

King, R. M. New spirosequiterpene lactones, germacra = nolides, and eudesmanolides from Wunderlichia mira = bilis. 228

King, R. M. New germacranolides, heliangolides, and elemanolides from Cronquistianthus chachapoyensis. 240

King, R. M. Epoxycannabinolide and diterpenes with a new carbon skeleton from Villanova titicaensis. 250

King, R. M. Heliangolides and trachylobane and villano $=$ vane derivatives from Viguiera species. 495

King, R. M. Pseudoguaianolides and other sesquiterp= enes from Monactis macbridei. 503

Klausener, A. Reactions of partially acylated aldohexo= pyranosides, II. Regioselective oxidation of partially acylated aldohexopyranosides with pyridinium $\mathrm{chlo}=$ rochromate and a new photochemical method for the preparation of methyl 3,6-dideoxy- $\alpha$-D-ribo-hexopy= ranoside. 783

Kleffel, D. Reactions of 1,4-pentadien-3-ones, 22 Synthesis and structure of the epimers of 3,5-diaryl-= 4-hydroxy-1,4-thiazinane 1,1-dioxides. 1013

Kleiner, E. Pteridines, LXXIV. Acylations of lumazines by radical nucleophilic substitution. 1798

Klemer, A. Iodination of monosaccharide derivatives with iodotrimethylsilane. 1052

Klemer, A. Lithium enolates of carbohydrates, 2. Axial $\alpha-\mathrm{C}$-methylation and -hydroxymethylation of carboh $=$ ydrate uloses. 1094

Klemer, A. One-step stereoselective syntheses of $\mathrm{C}-=$ branched $\alpha$-deoxycyclitols from 1,6-anhydrohexopyra = noses. 1662

Kliegel, W. Ring-chain isomerism of $\mathrm{N}-(1-$ carboxyal $=$ kyl)nitrones. I. C-Aryl-N-(1-carboxylalkyl)nitrones. 1545

Klose, W. Syntheses of thiazolo- and $[1,3]$ thiazino[1,2, $=$ 4]triazinones. 1302

Knoechel, T. Selective reactions of hydroazulenes: chiral norcarane derivatives by the reaction of a dihydroazulene with singlet oxygen. 773

Koeksal, Y. Cyclopentenone derivatives. VII. The stereoselective synthesis of brefeldin precursors. 450

Koeksal, Y. Cyclopentenone derivatives. VIII. Reac $=$ tions with acetoxycyclopentenones, brefeldin-A cycli= zations. 462

Koell, P. 1,6-Anhydrofuranoses, XIV. Selective mono= tosylation of 1,6-anhydro- $\beta-D$-mannofuranose. 1591

Koell, P. 1,6-Anhydrofuranoses, XV. Competitive preparation of $1,6: 2,5-$ and 1,6:3,5-dianhydro- $\alpha-\mathrm{L}-\mathrm{gu}=$ lofuranoses, ring opening of $1,6: 3,5$-dianhydro- $\alpha-\mathrm{L}-=$ gulofuranose. 1597

Koenig, W. A. Configuration and conformation of the nucleoside residues of the nikkomycins. 1216

Koenig, W. A. The structure of stenothricin - revision of a previous structure assignment. 1672

Koesling, V. Chelating vesicles made from $\mathrm{N}, \mathrm{N}$-dihexa= decyl-1,2-ethanediamine-N',N'-diacetic acid. 1634

Kohl, W. Antibiotics from gliding bacteria, XXII. Bios= ynthesis of myxopyronin A, an antibiotic from Myxo $=$ coccus fulvus, strain Mx f50. 1088

Kohla, M. One-step stereoselective syntheses of $\mathrm{C}-=$ branched $\alpha$-deoxycyclitols from 1,6-anhydrohexopyra $=$ noses. 1662

Kollenz, G. Structure of the 1:1 adducts of aryl isocyan= ides to 4-benzoyl-5-phenylfuran-2,3-dione and their = products with nucleophiles. Novel rearrangements of 5,5-disubstituted 4-methylenefuran-2,3-diones. 1137

Komander, H. 1,6-Anhydrofuranoses, XIV. Selective monotosylation of 1,6 -anhydro- $\beta-D-$ mannofuranose. 1591

Komander, H. 1,6-Anhydrofuranoses, XV. Competitive preparation of $1,6: 2,5-$ and 1,6:3,5-dianhydro- $\alpha-\mathrm{L}-\mathrm{gu}=$ lofuranoses, ring opening of 1,6:3,5-dianhydro- $\alpha-\mathrm{L}-=$ gulofuranose. 1597

Komori, T. Biologically active glycosides from Asteroi= dea. VII. Steroid oligoglycosides from the starfish Luidia maculata Mueller et Troschel. 2. The struc= tures of two new oligoglycoside sulfates. 296

Kovac, S. Contributions to the chemistry of tetrake $=$ tones, III. Synthesis and some reactions of 1,6-bis= (p-hydroxyphenyl)-1,3,4,6-hexanetetrone. 1755

Krebs, H. C. Biologically active glycosides from Asteroi= dea. VII. Steroid oligoglycosides from the starfish Luidia maculata Mueller et Troschel. 2. The struc= tures of two new oligoglycoside sulfates. 296 
Kresze, G. Polyhydroxyamino compounds via diene synthesis with nitroso compounds. IX. trans-6-Azi= do-1,3-cyclohexadien-5-ol as educt for the synthesis of condurodiamine and streptamine isomers. 203

Kresze, G. Chemistry of reactive cations derived from sulfur dioxide analogs. IX. Reactions with aliphatic carbodiimides. 900

Kresze, G. Chemistry of reactive cations derived from sulfur dioxide analogs. X. Reaction with aromatic carbodiimides - synthesis of benzothiadiazines. 904

Krohn, K. Intramolecular addition of carbanions to anthraquinones. 306

Krug, B. Boron complexes of malonamides and malo $=$ namidines. 370

Kubica, Z. Synthesis of peptides with $\alpha, \beta$-dehydroamino acids, I. Synthesis of $\mathrm{N}$-(benzyloxycarbonyl) and $\mathrm{N}$-(trifluoroacetyl) dipeptides of dehydroalanine and dehydrophenylalanine. 920

Kuembel, B. Synthesis of new carboximidoyl chlorides and their reaction with nucleophiles. 564

Kula, J. Synthesis of new tetrahydrofuran and tetrahy = dropyran derivatives from $\alpha$-pinene and 3-carene. 1860

Kunkel, E. Synthesis of 2-siloxy-substituted methyl cyclopropanecarboxylates. 512

Kunkel, E. Ring opening reactions of methyl 2-= silyloxycyclopropanecarboxylates to 4-oxoalkanoic acid derivatives. 802

Kunz, H. Synthesis of the methyl ether of cardenolide-= derived methylreductic acid starting from D-glucose. 66

Kunze, B. Antibiotics from gliding bacteria, XXIII. Stigmatellin A and B - two novel antibiotics from Stigmatella aurantiaca (Myxobacterales), 1883

Kurz, J. Albomycins, II. Absolute configuration of the deferri form of the albomycins. 1408

Laatsch, H. Dimeric naphthoquinones. IX. Isodiospyrin and elliptinone. Synthesis of 6,6'-dimeric bijuglones by phenol oxidation. 319

Laatsch, H. Dimeric naphthoquinones, XI. Oxidation products of substituted binaphthyls. 1367

Lacan, M. Contributions to the chemistry of tetrake= tones, III. Synthesis and some reactions of 1,6 -bis $=$ (p-hydroxyphenyl)-1,3,4,6-hexanetetrone. 1755

Ladner, W. Stereoselective synthesis of aicohols, XVIII Synthesis of $(3 S, 4 S)-4-m e t h y l-3-$ heptanol and of (5S,6S)-anhydroserricornin. 1170

Lay, K. L. Metal complexes with tetrapyrrole ligands XXXV. Synthesis of further more or less sterically hindered 5,15-dialkyloctaethylporphodimethenes by reductive alkylation of octaethylporphyrinatozinc. 1259

Lebuhn, R. Conformational analysis, XXIV. Determi= nation of the conformations of tri- and tetrasacchar = ide sequences of $\mathrm{N}$-glycoproteins. Problem of the $(1 \rightarrow$ 6)-glycosidic bond. 951

Lehmann,J. Reactions of enolic sugar derivatives, XVI. Synthesis of a diastereotopic proton probe $\{(\mathrm{Z})-3,7-=$ anhydro-1,2-dideoxy-D-gluco-oct-2-enitoll for $\alpha$ and $\beta-D$ glucosylases (correction). 1626

Lehmann, J. Reactions of enolic sugar derivatives, XVI. Synthesis of a diastereotopic proton probe [(Z)-3,7-anhydro-1,2-dideoxy-D-gluco-oct-2-enitol] for $\alpha-$ and $\beta-D-$ glucosidases. 1078

Lehmann, T. Metalloporphyrins in polymeric matrices, micelles, and vesicles. VI. Hydrophobic and hydro $=$ philic derivatives of 3,8-diformyldeuteroporphyrin dimethyl ester and their interaction with vesicles. 1057

Lehmann, T. Synthesis and reactivity of $13^{1}, 13^{2}, 17^{1},=$ $17^{2}$ tetradehydrodeuteroporphyrin. 1386

Lehmann, W. D. The structure of stenothricin - revision of a previous structure assignment. 1672

Lehnert, $\mathbf{R}$. A contribution to the structural assignment of positional isomers of bis-galacto and bis-manno crown ethers. 1046

Lendering, U. 1,6-Anhydrofuranoses, XIV. Selective monotosylation of 1,6-anhydro- $\beta-D$-mannofuranose. 1591

Lendering, U. 1,6-Anhydrofuranoses, XV. Competitive preparation of 1,6:2,5- and 1,6:3,5-dianhydro- $\alpha-\mathrm{L}-\mathrm{gu}=$ lofuranoses, ring opening of 1,6:3,5-dianhydro- $\alpha-\mathrm{L}^{-}=$ gulofuranose. 1597

Leszczynska, E. Chemistry of hydroxamic acids. 10. A convenient rearrangement of 4-quinolinecarbohydrox= amic acid. 395

\section{Liebigs Ann. Chem. 1984}

Liman, U. ara-7-Deazaxanthosine - a xanthine nucleo $=$ side with a stabile $\mathrm{N}-$ glycosylic bond. 273

Lipczynska-Kochany, E. Chemistry of hydroxamic acids. 10. A convenient rearrangement of 4-quinoli= necarbohydroxamic acid. 395

Loesch, N. Dehydrogenation reactions with gallic acid esters. 929

Loewe, $\mathbf{W}$. Note on the synthesis of 1,2-benzoxathiin 2,2-dioxide derivatives from 3-chromonesulfonic acid. 1395

Lorenz, J. Syntheses of thiazolo- and $[1,3]$ thiazino[1,2, = 4) triazinones. 1302

Lorke, M. 4-Imidazolidinones from nitrones and iso $=$ cyanides. Molecular structure of 5-tert-butyl-1,2,2-= trimethyl-3-(2,4,6-tribromophenyl)-4-imidazolidi= none. 1685

Ludwig, G. W. New spirosequiterpene lactones, germa= cranolides, and eudesmanolides from Wunderlichia mirabilis. 228

Lueckenhaus, W. Organosilicon compounds. LXXXIV. $\beta$-Lactams. III. $\beta$-Lactams via $\mathrm{N}$-silylcarbodiimides 1193

Luger, P. Cycloaddition with unsaturated carbohyd $=$ rates, III. The stereochemistry of the Diels-Alder reaction with hex-2-enopyranoside and hex-2-enopy= ranosid-4-uloses. 1531

Maier, T. Orthoamides. XI. Preparation of $1,1,2,3,3-=$ penta-substituted and 1,1,2,2,3,3-hexa-substituted guanidinium salts and 1,1,2,3,3-pentaalkylguanidines. 108

Makosza, M. Reactions of organic anions. 113. Vicari= ous nucleophilic substitution of hydrogen in nitropyri= dines by $\alpha$-chloroalkyl phenyl sulfone carbanions. 8

Makowski, M. Synthesis of peptides with $\alpha, \beta$-dehy $=$ droamino acids, I. Synthesis of $\mathrm{N}$-(benzyloxycarbo $=$ nyl) and $\mathrm{N}$-(trifluoroacetyl) dipeptides of dehydroala = nine and dehydrophenylalanine. 920

Malik, A. Stereospecific syntheses of D-ossamine and D-tolyposamine. 636

Markowska, A. Thiophosphatidic acid esters containing a carbon-sulfur-phosphorus bond. 1

Martin, R. Azolides, 7. Phosphonate and phosphate group transfer with pyrazolides. 1641

Marx, K. H. Cyclopentenone derivatives. IX. Enantios= elective routes to brefeldin-A. 474

Matyus, P. Reactions of uracils, 4. Some aspects of the chemistry of pyrido[2,3-d]pyrimidines. A novel $\mathrm{s}^{-}=$ triazolo[4 $\left.4^{\prime}, 3^{\prime}: 1,6\right]$ pyrido[2,3-d]pyrimidine. 1653

Mayer, W. Dehydrogenation reactions with gallic acid esters. 929

Meier, L. Reactions of carboxonium ions of cyclic ace $=$ tals, VIII. Synthesis of $( \pm)-4,5,6,7$-tetrahydro-3,7-di= methyl-1-benzofuran. 1298

Meister, C. Diastereoselective synthesis of (1RS)-endo-= brevicomin. 147

Mengel, R. Pteridines, LXXV. Synthesis and properties of biopterin and biopterin analogs. 1815

Mentlein, R. A new method for the degradation of anthocyanidins, flavones, chalcones, and coumarins. 401

Mentlein, R. The red membrane pigments of the peat moss Sphagnum rubellum. 1024

Mergen, W. W. Orthoamides. XI. Preparation of $1,1,2,3,=$ 3 -penta-substituted and $1,1,2,2,3,3$-hexa-substituted guanidinium salts and 1,1,2,3,3-pentaalkylguanidines. 108

Mester, I. Studies of the chemistry of natural organic materials. 89 . Halogenation reactions of $1,3-$ dihydr $=$ oxy-10-methyl-9(10H)-acridinone and its ethers - a simple regiospecific synthesis of acronycine. 31

Metzger, J. O. 1,6-Anhydrofuranoses, XV. Competitive preparation of 1,6:2,5- and 1,6:3,5-dianhydro- $\alpha-\mathrm{L}-\mathrm{gu}=$ lofuranoses, ring opening of $1,6: 3,5$-dianhydro- $\alpha-L-=$ gulofuranose. 1597

Meyer, B. Conformational analysis, XXIV. Determina $=$ tion of the conformations of tri- and tetrasaccharide sequences of $\mathrm{N}-$ glycoproteins. Problem of the $(1 \rightarrow$ 6)-glycosidic bond. 951

Meyer, B. 1,6-Anhydrofuranoses, XIV. Selective mono= tosylation of 1,6-anhydro- $\beta-D$-mannofuranose. 1591

Meyer, H. H. Syntheses of $(+)$-oudemansin and $(+)-e p=$ ioudemansin starting from enantiomerically pure precursors; absolute configuration of the naturally occurring (-)-oudemansin. 791

Meyer, H. H. Syntheses and absolute configurations of $(+)-\left(6 \mathrm{R}, 2^{\prime} \mathrm{S}\right)$-cryptocaryalactone and $(-)-(6 \mathrm{~S}, 2 \mathrm{~S})-\mathrm{epi}=$ cryptocaryalactone. 977 
Mezey-Vandor, G. A simple method for the preparation of 2-arylbenzofurans and the synthesis of moracin A and $B .734$

Michel, J. Glycosyl imidates, 12. Direct synthesis of $0-\alpha-$ and $0-\beta$-glycosyl imidates. 1343

Michels, W. Syntheses of 5'-capped oligoribonucleo= tides. 867

Minami, T. Chemistry of reactive cations derived from sulfur dioxide analogs. X. Reaction with aromatic carbodiimides - synthesis of benzothiadiazines. 904

Mlotkowska, B. Thiophosphatidic acid esters containing a carbon-sulfur-phosphorus bond.

Moderhack, D. 3-Phenyl-1,2,4-triazole-5-carbaldeh= ydes substituted in position 1.48

Moderhack, D. 4-Imidazolidinones from nitrones and isocyanides. Molecular structure of 5-tert-butyl-1,2, = 2-trimethyl-3-(2,4,6-tribromophenyl)-4-imidazolidi= none. 1685

Mori, K. Pheromone synthesis. LXIV. Synthesis of the enantiomers of 2-methyl-1,7-dioxaspiro[5.6]dode $=$ cane, a component of the volatile secretion from the mandibular glands of Andrena haemorrhoa F. 157

Morita, T. Multistep reversible redox systems, XXXIX. Isomeric biazulenyls: UV/VIS spectroscopy, voltam = metry, and HMO energies. 1952

Mudryk, B. Reactions of organic anions. 113. Vicarious nucleophilic substitution of hydrogen in nitropyridines by $\alpha$-chloroalkyl phenyl sulfone carbanions. 8

Mueller, E. Chemistry of nitrosamines, IV. Syntheses of $\alpha$-C-functionalized $\mathrm{N}$-nitrosodialkylamines: esters and ethers of $1-[($ alkyl)(nitroso)amino]alcohols. 1468

Mueller, U. Intramolecular addition of carbanions to anthraquinones. 306

Mueller-Menke, C. Note on the synthesis of 1,2-ben= zoxathiin 2,2-dioxide derivatives from 3-chromonesul= fonic acid. 1395

Nagy, Z. Synthesis of the pterocarpan constituents of Swartzia laevicarpa. 127

Nalic, G. Contributions to the chemistry of tetrake $=$ tones. II. Reaction of 3,4-dibenzoyl-2,5-hexanedione with hydroxylamine. 199

Naumann, A. Synthesis of the Lycopodium alkaloid rac-luciduline from hexahydro-7-methylquinoline. 1519

Neunhoeffer, H. Synthesis of 1,2,4-triazines. XI. Syn $=$ thesis and reactions of 6-amino-1,2,4-triazin-5-ones and 6-amino-1,2,4-triazine-5-thiones. 283

Nielsen, F. E. Annulated 1,2,3-triazoles, I. Synthesis of 8-azapurin-6-ones and 8-azapurin-6-imines from ethyl 5-(acetylamino)-1,2,3-triazole-4-carboxylates. 1848

Nixdorf, M. Chemistry and stereochemistry of iridoids, IV. Synthesis and $x$-ray structure analysis of 15-me= thyl-12-epi-prostaglandin $\mathrm{F}_{2 \beta} .761$

Nogradi, M. Synthesis of the pterocarpan constituents of Swartzia laevicarpa. 127

Nogradi, M. A simple method for the preparation of 2-arylbenzofurans and the synthesis of moracin $A$ and $\mathrm{B}$. 734

Nogradi, M. An attempted synthesis of polystachin 1068

Ognyanov, V. Reactions of glutaconic and homophthalic anhydrides with imidates, imidoyl chlorides, and 1-chloroisoquinoline. 389

Ort, B. Multistep reversible redox systems. XXXV. Voltammetry of vinylogous polyenes with cross-conju= gated end groups and UV/VIS spectroscopy of their radical anions and cations. 354

Ort, B. Multistep reversible redox systems, XXXVII. Biazulenyls and $\omega, \omega^{\prime}$-diazulenylpolyenes: syntheses and spectroscopic properties. 1905

Ort, B. Multistep reversible redox systems, XXXVIII. Biazulenyls and $\omega, \omega^{\prime}$-diazulenylpolyenes: reaction with protic aciois, nucleophiles, and reducing and oxidizing agents. 1936

Ort, B. Multistep reversible redox systems, XXXIX. Isomeric biazulenyls: UV/VIS spectroscopy, voltam = metry, and HMO energies. 1952

Ort, B. Multistep reversible redox systems, XL. $\omega, \omega^{\prime}-=$ Biazulenyl polyenes: voltammetry and $\mathrm{HMO}$ ener $=$ gies. 1959

Ott, G. Syntheses of mesityl-substituted azulenes. 1605

Ott, J. The $\left(2^{\prime} \rightarrow 5^{\prime}\right)$ - and $\left(3^{\prime} \rightarrow 5^{\prime}\right)$-tubercidylyl tuber $=$ cidins - synthesis via phosphite triester and studies of secondary structure. 692
Ott, W. Reactions with isocyanides. Synthesis of dark-= blue dyes from 1,4-quinones and aryl isocyanides. 1003

Ott, W. Structure of the 1:1 adducts of aryl isocyanides to 4-benzoyl-5-phenylfuran-2,3-dione and their products with nucleophiles. Novel rearrangements of 5,5-disubstituted 4-methylenefuran-2,3-diones. 1137

Otto, H. H. Reactions of 1,4-pentadien-3-ones, 22. Synthesis and structure of the epimers of 3,5-diaryl-= 4-hydroxy-1,4-thiazinane 1,1-dioxides. 1013

Papaioannou, D. Application of N-trityl amino acid 1-benzotriazolyl esters in peptide synthesis. 1308

Parodi, B. Constituents of Cupuliferae, 8. A novel, highly-acylated astragalin from Quercus ilex L. 1864

Parodi, B. Constituents of Cupuliferae, 9. An unusual diester of astragalin with cis-and trans-p-coumaric acid from Quercus ilex L. 1867

Parodi, B. Constituents of Boraginaceae, 7. Anchuso= side -8 and -9 : two new triterpene saponins from Anchusa officinalis L. 1869

Paul, A. H. K. Synthesis of rac $-4 \beta$-hydroxyobovata $=$ chromene. 1382

Paulsen, H. Cyclitol reactions. X. Synthesis of enan= tiomerically pure pseudo- $\alpha-\mathrm{D}-$ galactopyranose and pseudo- $\beta$-D-mannopyranose. 433

Paulsen, H. Conformational analysis, XXIV. Determi= nation of the conformations of tri- and tetrasacchar = ide sequences of $\mathrm{N}$-glycoproteins. Problem of the $(1 \rightarrow$ 6)-glycosidic bond. 951

Paulsen, H. Synthons of oligosaccharides, LII. Synthe= sis of disaccharides from 3-deoxy-D-manno-2-octulo $=$ sonic acid (KDO) and D-glucosamine. 1270

Paulsen, H. Synthons of oligosaccharides, LIII. Synthe sis of trisaccharides containing 3-deoxy-D-manno-2-= octulosonic acid (KDO). 1288

Paulsen, H. Albomycins, II. Absolute configuration of the deferri form of the albomycins. 1408

Pedersen, E. B. Annulated 1,2,3-triazoles, I. Synthesis of 8-azapurin-6-ones and 8-azapurin-6-imines from ethyl 5-(acetylamino)-1,2,3-triazole-4-carboxylates. 1848

Peters, E. M. Structure of the $1: 1$ adducts of aryl iso $=$ cyanides to 4-benzoyl-5-phenylfuran-2,3-dione and their products with nucleophiles. Novel rearrange $=$ ments of 5,5-disubstituted 4-methylenefuran-2,3-= diones. 1137

Peters, K. Structure of the 1:1 adducts of aryl isocyan= ides to 4-benzoyl-5-phenylfuran-2,3-dione and their products with nucleophiles. Novel rearrangements of 5,5-disubstituted 4-methylenefuran-2,3-diones. 1137

Peters, T. Conformational analysis, XXIV. Determina $=$ tion of the conformations of tri- and tetrasaccharide sequences of $\mathrm{N}$-glycoproteins. Problem of the $1 \rightarrow$ 6)-glycosidic bond. 951

Pfleiderer, W. Pteridines, LXXIV. Acylations of luma= zines by radical nucleophilic substitution. 1798

Pfleiderer, $\mathbf{W}$. Pteridines, LXXV. Synthesis and pro $=$ perties of biopterin and biopterin analogs. 1815

Pipereit, E. Heterocycles from $\alpha$-nitroolefins, VII. 4,5-Dihydro-2-methyl-5-(methyleneamino)-3-furan= carboxylates from $\alpha$-nitroolefins, acetoacetates, and compounds with an active methylene group. 911

Platen, M. Oxidative deblocking of the 4-methoxyben = zyl thioether protecting group: application to the directed synthesis of polycystinyl peptides. 1563

Plesch, W. Syntheses of $\alpha-\mathrm{C}$-functionalized $\mathrm{N}$-nitro $=$ dialkylamines: esters of [(alkyl)(nitro)amino]metha $=$ nol and $1-[($ alkyl)(nitro)amino]ethanol. 1494

Plieninger, $\mathbf{H}$. Synthesis of stereoisomeric 3,4-dihydro= bilirubinic acid derivatives as synthons for bile pig= ments. 1441

Plieninger, H. Synthesis of rac-stercobilin IX $\alpha$ with the configuration of the natural product and of some urobilins, half-stercobilins, and stercobilins with unequivocal constitution and configuration. 1454

Poncini, L. A convenient synthesis of phenylpropargy= laldehyde diethyl acetal. 1529

Pressler, W. Syntheses with aliphatic dialdehydes, XXXVIII. Synthesis and properties of cycloalkylmal= onaldehydes. 649

Preut, H. Enehydrazines, 37. Synthesis of a pyrazole analog of 7-aminomitosene. 1711

Priyono, W. Intramolecular addition of carbanions to anthraquinones. 306 
Quast, H. Synthesis and reactions of some pyrido[3,2-= g]quinolines (1,8-diazaanthracenes). 133

Quast, H. 1-Aza- and 1,9-diazatriptycenes. 381

Quast, H. $5,10-$ Bridged pyrido[3,2-g]quinolines via $[4+$ 2] cycloaddition of dienophiles to pyrido $[3,2-\mathrm{g}]$ quino $=$ lines. 877

Quast, $\mathbf{H}$. Structure of the 1:1 adducts of aryl isocyan= ides to 4-benzoyl-5-phenylfuran-2,3-dione and their products with nucleophiles. Novel rearrangements of 5,5-disubstituted 4-methylenefuran-2,3-diones. 1137

Quast, H. 1,5-Dimethylbicyclo[3.3.0]octane-2,6-dione and 1,5-dimethylbicyclo[3.3.0]octa-3.7-diene-2,6-= dione. Basic synthons for substituted semibullval= enes. 1180

Raddat $x, P$. Cyclopentenone derivatives. VII. The stereoselective synthesis of brefeldin precursors. 450

Raddatz, P. Cyclopentenone derivatives. VIII. Reac $=$ tions with acetoxycyclopentenones, brefeldin-A cycli= zations. 462

Raddatz, P. Cyclopentenone derivatives. IX. Enantios= elective routes to brefeldin-A. 474

Rapic, V. Contributions to the chemistry of tetrake $=$ tones, III. Synthesis and some reactions of 1,6-bis $=$ (p-hydroxyphenyl)-1,3,4,6-hexanetetrone. 1755

Rathmann, R. Configuration and conformation of the nucleoside residues of the nikkomycins. 1216

$\mathbf{R a u}, \mathbf{O}$. Tetrahydrofuran acids - a new class of com $=$ pounds in human metabolism. 1504

Rau, O. Origin of 3,6-epoxyalkanedioic acids in human urine. 1513

Regitz, M. Azolides, 7. Phosphonate and phosphate group transfer with pyrazolides. 1641

Reichardt, C. Syntheses with aliphatic dialdehydes, XXXVIII. Synthesis and properties of cycloalkylmal= onaldehydes. 649

Reichelt, I. Synthesis of 2-siloxy-substituted methyl cyclopropanecarboxylates. 512

Reichelt, I. Deprotonation and diastereoselective alkyla = tion of 2-siloxy-substituted methyl cyclopropanecarb = oxylates. 531

Reichelt, I. Ring opening reactions of methyl 2-0 silyloxycyclopropanecarboxylates to 4-oxoalkanoic acid derivatives. 802

Reichelt, I. Flexible and efficient synthesis of methyl 4-oxo-2-alkenoates. 820

Reichelt, I. Ring opening of methyl 2-(trimethylsilylme $=$ thyl)cyclopropanecarboxylate. 828

Reichenbach, H. Antibiotics from gliding bacteria, XXII. Biosynthesis of myxopyronin A, an antibiotic from Myxococcus fulvus, strain Mx f50. 1088

Reichenbach, H. Antibiotics from gliding bacteria, XXIII. Stigmatellin A and B - two novel antibiotics from Stigmatella aurantiaca (Myxobacterales). 1883

Reisch, J. Studies of the chemistry of natural organic materials. 89. Halogenation reactions of 1,3 -dihydr $=$ oxy-10-methyl-9(10H)-acridinone and its ethers - a simple regiospecific synthesis of acronycine. 31

Reissig, H. U. Synth'esis of 2-siloxy-substituted methyl cyclopropanecarbo:xylates. 512

Reissig, H. U. Depro,tonation and diastereoselective alkylation of 2 -silo, $x y$-substituted methyl cyclopropa $=$ necarboxylates. $5 \%$

Reissig, H. U. Ring wpening reactions of methyl 2-= silyloxycyclopropanecarboxylates to 4-oxoalkanoic acid derivatives. 802

Reissig, H. U. Flexible and efficient synthesis of methyl 4-oxo-2-alkenoates. 820

Reissig, H. U. Ring opening of methyl 2-(trimethylsilylmethyl)cyclopropanecarboxylate. 828

Ried, W. Synthesis of new carboximidoyl chlorides and their reaction with nucleophiles. 564

Ried, $\mathbf{W}$. Chemistry of dimethyl $(1 \alpha, 2 \beta, 5 \beta, 6 \alpha, 7 \beta, 8 \beta)-3=$ 4-dioxotricyclo[4.2.1.02.5]nonane-7,8-dicarboxylate. 1109

Ried, W. The behavior of $(1 \alpha, 2 \alpha, 5 \alpha, 6 \alpha)-3,4$-bis(trime $=$ thylsiloxy)tricyclo[4.2.1.02,5]nona-3,7-diene on treat $=$ ment with oxidative reagents. 1778

Rinken, $M$. The structure of stenothricin - revision of a previous structure assignment. 1672

Robinson, H. New sesquiterpene lactones and rosane derivatives from Trichogonia species. 162

Robinson, H. New spirosequiterpene lactones, germacra $=$ nolides, and eudermanolides from Wunderlichia mira = bilis. 228
Robinson, H. New germacranolides, heliangolides, and elemanolides from Cronquistianthus chachapoyensis. 240

Robinson, H. Epoxycannabinolide and diterpenes with a new carbon skeleton from Villanova titicaensis. 250

Robinson, H. Heliangolides and trachylobane and villa= novane derivatives from Viguiera species. 495

Robinson, H. Pseudoguaianolides and other sesquiterp $=$ enes from Monactis macbridei. 503

Rodewald, H. Chemistry and stereochemistry of iri= doids, IV. Synthesis and $x$-ray structure analysis of 15-methyl-12-epi-prostaglandin $\mathrm{F}_{2 \beta} .761$

Roeben, W. Cyclitol reactions. X. Synthesis of enan $=$ tiomerically pure pseudo- $\alpha-D-$ galactopyranose and pseudo- $\beta-D$-mannopyranose. 433

Romussi, G. Constituents of Cupuliferae, 8. A novel, highly-acylated astragalin from Quercus ilex L. 1864

Romussi, G. Constituents of Cupuliferae, 9. An unusual diester of astragalin with cis-and trans-p-coumaric acid from Quercus ilex L. 1867

Romussi, G. Constituents of Boraginaceae, 7. Anchuso $=$ side -8 and -9 : two new triterpene saponins from Anchusa officinalis L. 1869

Roos, M. Glycosyl imidates, 12. Direct synthesis of $\mathrm{O}-\alpha$ - and $\mathrm{O}-\beta$-glycosyl imidates. 1343

Rosenberg, D. 7-Aroyl-1 H,7H-s-triazolo[1,2-a]-s-tria = zole-1,3(2H)-diones, a new class of compounds from 5-phenyloxazoles and 4-phenyl-4H-1,2,4-triazole-3, = 5-dione. 641

Rottegger, S. Trifluoromethyl-substituted pyrimidines from enamines and trifluoroacetonitrile. 991

Rubio Encinas, M. J. Synthesis of heterocyclic com= pounds. XXXVII. Preparation of 4,6-diaryl-1,2-dihy= dro-2-thioxo-3,5-pyridinedicarbonitriles and related compounds. 213

Ruff, J. Syntheses of antimicrobial biscationic $2-$ (phen $=$ oxyphenyl)indoles and -1 -benzofurans. 409

Ruhr, M. Nef reaction. VI. 4,5-Dihydro-5-(methyle= neamino)-3-furancarboxylates. 223

Ruhr, M. Heterocycles from $\alpha$-nitroolefins, VII. 4,5-= Dihydro-2-methyl-5-(methyleneamino)-3-furancarb $=$ oxylates from $\alpha$-nitroolefins, acetoacetates, and com = pounds with an active methylene group. 911

Runsink, J. Reactions of partially acylated aldohexopy= ranosides, II. Regioselective oxidation of partially acylated aldohexopyranosides with pyridinium chlo = rochromate and a new photochemical method for the preparation of methyl 3,6-dideoxy-a-D-ribo-hexopy $=$ ranoside. 783

Runsink, J. Reactions of carboxonium ions of cyclic acetals, VIII. Synthesis of $( \pm)-4,5,6,7$-tetrahydro-3, = 7-dimethyl-1-benzofuran. 1298

Rzeszotarska, B. Synthesis of peptides with $\alpha, \beta$-dehy $=$ droamino acids, I. Synthesis of $\mathrm{N}$-(benzyloxycarbo $=$ nyl) and $\mathrm{N}$-(trifluoroacetyl) dipeptides of dehydroala $=$ nine and dehydrophenylalanine. 920

Saadatmandi, A. Reaction of diphenylcyclopropenone with allylidenetriphenylphosphoranes. 1989

Sancassan, F. Constituents of Cupuliferae, 8. A novel, highly-acylated astragalin from Quercus ilex L. 1864

Sancassan, F. Constituents of Cupuliferae, 9. An unu $=$ sual diester of astragalin with cis- and trans-p-coum = aric acid from Quercus ilex L. 1867

Sanida, C. Application of N-trityl amino acid 1-benzo $=$ triazolyl esters in peptide synthesis. 1308

Sarstedt, B. Intramolecular addition of carbanions to anthraquinones. 306

Sauer, M. $[2.2](2,7)$ Anthracenophane: synthesis and conformational studies. 615

Sauer, M. Cycloarenes, a new class of aromatic com= pounds. IV. Attempts to synthesize cyclo/d.e.e.d.e.e. d.e.e.]nonakisbenzene and cyclo[d.e.d.e.d.e.d.e.d.e]de = cakisbenzene. 742

Schaefer, H. Synthesis of 4-aminocinnolines from (arylhydrazono)(cyano)acetic acid derivatives. 1390

Schanbacher, U. Syntheses of peptide alkaloids, IX. Amino acids and peptides, XLVI. Total synthesis of mucronin B. 1205

Scharf, H. D. Diastereoselective synthesis of (1RS)-= endo-brevicomin. 147

Scharf, H. D. Reactions of partially acylated aldohexo= pyranosides, II. Regioselective oxidation of partially acylated aldohexopyranosides with pyridinium chlo $=$ rochromate and a new photochemical method for the preparation of methyl 3,6-dideoxy- $\alpha$-D-ribo-hexopy $=$ ranoside. 783 
Scharf, H. D. Reactions of carboxonium ions of cyclic acetals, VIII. Synthesis of $( \pm)-4,5,6,7$-tetrahydro-3, = 7-dimethyl-1-benzofuran. 1298

Scheuer, R. Asymmetric synthesis via heterocyclic intermediates, XXIII. Studies of the enantioselective synthesis of $\alpha$-alkyl- $\alpha$-(2-furyl)glycines by alkylation of 3-(2-furyl)-3,6-dihydro-2H-1,4-oxazin-2-ones chirally substituted at C-6, 939

Schiebel, H. M. Syntheses with nucleic acid consti= tuents, X. Mass spectrometry of nucleotides, VII. Synthesis of deoxyoligonucleotide linker fragments for genetic engineering using improved preparative and analytical techniques. 835

Schildknecht, H. Synthesis of the first leaf movement factor from Mimosa pudica L. 1230

Schilling, G. Dehydrogenation reactions with gallic acid esters. 929

Schilling-Pindur, A. Preparation of sulfonioindenides. 552

Schinzel, E. Naphthylenedi(heteroarenes), III. Synthe $=$ sis and spectroscopic behavior of $2,2^{\prime}$-naphthylenedi= benzazoles. 1129

Schlimme, E. Synthesis and conformational analysis of some 5'-homoadenosine derivatives. 98

Schlimme, E. Syntheses of 5'-capped oligoribonucleo= tides. 867

Schmalle, $\mathbf{H}$. Configuration and conformation of the nucleoside residues of the nikkomycins. 1216

Schmeda-Hirschmann, G. Heliangolides and trachylo= bane and villanovane derivatives from Viguiera spe $=$ cies. 495

Schmidt, D. Albomycins, IV. Isolation and total syn= thesis of (N5-acetyl- $\mathrm{N}^{5}$-hydroxy-L-ornithyl) $\left(\mathrm{N}^{5}\right.$-ace $=$ tyl-N5-hydroxy-L-ornithyl)- $\mathrm{N}^{5}$-acetyl- $\mathrm{N}^{5}$-hydroxy-= L-ornithine. 1434

Schmidt, J. Properties of an (arylthiomethylene) $c y c l o=$ hexanone. 576

Schmidt, R. R. Glycosyl imidates, 10. Glycosyl phosp $=$ hates from glycosyl trichloroacetimidates. 680

Schmidt, R. R. Glycosyl imidates, 12. Direct synthesis of $\mathrm{O}-\alpha-$ and $\mathrm{O}-\beta$-glycosyl imidates. 1343

Schmidt, R. R. Glycosyl imidates, 13. Application of the trichloroacetimidate procedure to 2-azidoglucose and 2-azidogalactose derivatives. 1826

Schmidt, U. Syntheses of peptide alkaloids, IX. Amino acids and peptides, XLVI. Total synthesis of mucro= $\operatorname{nin}$ B. 1205

Schoellkopf, U. Synthesis and biological activities of the antibiotic B 371 and its analogs. 600

Schoellkopf, U. Synthesis with $\alpha$-metalated isocyan $=$ ides. LIII. Synthesis of methyl 2,3-epoxy-2-isocya= noalkanoates. 608

Schoellkopf, U. Asymmetric synthesis via heterocyclic intermediates, XXIII. Studies of the enantioselective synthesis of $\alpha$-alkyl- $\alpha$-(2-furyl)glycines by alkylation of 3-(2-furyl)-3,6-dihydro-2H-1,4-oxazin-2-ones chirally substituted at $\mathrm{C}-6.939$

Schoen, N. Synthesis and reactions of some pyrido[3,2-= g]quinolines (1,8-diazaanthracenes). 133

Schoen, N. 1-Aza- and 1,9-diazatriptycenes. 381

Schoen, N. 5,10-Bridged pyrido[3,2-g]quinolines via $[4+$ 2] cycloaddition of dienophiles to pyrido[3,2-g]quino $=$ lines. 877

Schoenberger, G. Chelating vesicles made from $\mathrm{N}, \mathrm{N}-\mathrm{di}=$ hexadecyl-1,2-ethanediamine-N',N'-diacetic acid. 1634

Scholz, D. New synthetic methods. 9. S-Alkyl 4-me= thylbenzenethiosulfonates, excellent reagents for $\alpha$-thiolation of cyclic ketones. 259

Scholz, D. New synthetic methods. 10. $\beta$-Keto sulfones as ethylene carbanion equivalents: the synthesis of unsaturated carboxylic acids. 264

Schomburg, D. 4-Imidazolidinones from nitrones and isocyanides. Molecular structure of 5-tert-butyl-1,2, = 2-trimethyl-3-(2,4,6-tribromophenyl)-4-imidazolidi= none. 1685

Schramm, G. Antibiotics from basidiomycetes, XX. Synthesis of strobilurin A and revision of the stereo= chemistry of natural strobilurins. 1616

Schroeder, G. Crown ethers with triose and pentose structural units. 1036

Schroeder, G. A contribution to the structural assign= ment of positional isomers of bis-galacto and bis- $=$ manno crown ethers. 1046

Schulten, H. R. Syntheses with nucleic acid consti= tuents, X. Mass spectrometry of nucleotides, VII.
Synthesis of deoxyoligonucleotide linker fragments for genetic engineering using improved preparative and analytical techniques. 835

Schumann, D. Synthesis of the Lycopodium alkaloid rac-luciduline from hexahydro-7-methylquinoline. 1519

Schumann, I. 7-Aroyl-1 H,7H-s-triazolo[1,2-a]-s-tria= zole-1,3(2H)-diones, a new class of compounds from 5-phenyloxazoles and 4-phenyl-4H-1,2,4-triazole-3, 5-dione. 641

Schwalge, B. Antibiotics from basidiomycetes, XX. Synthesis of strobilurin A and revision of the stereo= chemistry of natural strobilurins. 1616

Schwarting, W. 1,6-Anhydrofuranoses, XV. Competi= tive preparation of $1,6: 2,5-$ and $1,6: 3,5$-dianhydro- $\alpha-=$ L-gulofuranoses, ring opening of $1,6: 3,5$-dianhydro- $=$ $\alpha$-L-gulofuranose. 1597

Schwarz, K. Syntheses of thiazolo- and $[1,3]$ thiazino[1, = $2,4]$ triazinones. 1302

Schwickerath, W. Aminoethynyl metalations. 13. Synthesis and reactions of 3-aminopropiolamidines. 85

Schwoebel, A. Chemistry of reactive cations derived from sulfur dioxide analogs. IX. Reactions with alip $=$ hatic carbodiimides. 900

Schwoebel, A. Chemistry of reactive cations derived from sulfur dioxide analogs. X. Reaction with aromat $=$ ic carbodiimides - synthesis of benzothiadiazines. 904

Seebach, D. Enantiomerically pure synthons from branched malates (correction). 407

Seela, F. ara-7-Deazaxanthosine - a xanthine nucleoside with a stabile $\mathrm{N}$-glycosylic bond. 273

Seela, F. The $\left(2^{\prime} \rightarrow 5^{\prime}\right)$ - and $\left(3^{\prime} \rightarrow 5^{\prime}\right)$-tubercidylyl tubercidins - synthesis via phosphite triester and studies of secondary structure. 692

Seela, F. Synthesis and furanoside/pyranoside isomeri= zation of 7-deaza-2'-deoxy-7-methylguanosine. 708

Seela, F. 7-( $\beta-\mathrm{D}-$ Arabinofuranosyl $)-2,4-$ dichloro-7H- $=$ pyrrolo[2,3-d]pyrimidine - synthesis, selective dis $=$ placement of halogen, and effect of glyconic protecting groups on the reactivity of the aglycon. 722

Seela, F. Synthesis of 2'-deoxyribofuranosides of $7 \mathrm{H}-=$ pyrrolo[2,3-d]pyrimidine: effect of the C-2 substi= tuents on the fluorescence. 1719

Seela, F. Anomers of tubercidin derivatives with 2-me= thylthio and $\mathrm{N}^{4}-\left(\Delta^{2}\right.$-isopentenyl) residues. 1972

Seidenspinner, H. M. Reactions with isocyanides. Synthesis of dark-blue dyes from 1,4-quinones and aryl isocyanides. 1003

Seliger, H. Syntheses with nucleic acid constituents, X. Mass spectrometry of nucleotides, VII. Synthesis of deoxyoligonucleotide linker fragments for genetic engineering using improved preparative and analytical techniques. 835

Seoane, C. Synthesis of heterocyclic compounds. XXXVII. Preparation of 4,6-diaryl-1,2-dihydro-2-= thioxo-3,5-pyridinedicarbonitriles and related $\mathrm{com}=$ pounds. 213

Sheldrick, W. S. Antibiotics from gliding bacteria $X V I I I$. The absolute configuration of myxalamide $A$ and $B .78$

Sheldrick, W. S. Lactonic constituents of Angelica glauca. 888

Shen, Z. Diastereoselective synthesis of (1RS)-endo-= brevicomin. 147

Siemanowski, $\mathbf{W}$. Synthesis and properties of 2,2'-bipy= ridin-3-ols and -3,3'-diols. 1731

Siewert, G. Syntheses with nucleic acid constituents, X. Mass spectrometry of nucleotides, VII. Synthesis of deoxyoligonucleotide linker fragments for genetic engineering using improved preparative and analytical techniques. 835

Simchen, G. Sulfosilylation of carbonyl compounds and trimethylsilyl enol ethers with trimethylsilyl chloro $=$ sulfonate. 39

Simmerl, R. 4H-1,3,5-Oxadiazines and $4 \mathrm{H}-1,3,5-$ thia $=$ diazines from cyanamides and perhalo ketones and thio ketones. 982

Sinnwell, V. Conformational analysis, XXIV. Determi= nation of the conformations of tri- and tetrasacchar= ide sequences of $\mathrm{N}$-glycoproteins. Problem of the $(1 \rightarrow$ 6)-glycosidic bond. 951

Sinnwell, V. Albomycins, II. Absolute configuration of the deferri form of the albomycins. 1408 
Sohar, P. Reactions of uracils, 4. Some aspects of the chemistry of pyrido[2,3-d]pyrimidines. A novel $\mathrm{s}^{-}=$ triazolo $\left[4^{\prime}, 3^{\prime}: 1,6\right]$ pyrido $[2,3-d]$ pyrimidine. 1653

Soto, J. L. Synthesis of heterocyclic compounds. XXXVII. Preparation of 4,6-diaryl-1,2-dihydro-2thioxo-3,5-pyridinedicarbonitriles and related com = pounds. 213

Speh, P. Orthoamides. XI. Preparation of 1,1,2,3,3-pen= ta-substituted and $1,1,2,2,3,3$-hexa-substituted guani= dinium salts and $1,1,2,3,3$-pentaalkylguanidines. 108

Spiteller, G. Piperine - an example of an individually different (polymorphic) metabolism of an omnipresent nutritional component. 1319

Spiteller, G. Tetrahydrofuran acids - a new class of compounds in human metabolism. 1504

Spiteller, G. Origin of 3,6-epoxyalkanedioic acids in human urine. 1513

Staab, H. A. Cycloarenes, a new class of aromatic com $=$ pounds. III. Studies towards the synthesis of $\mathrm{cyclo}^{\circ}=$ [d.e.d.e.e.d.e.d.e.e.]decakisbenzene (correction). 408

Staab, H. A. [2.2](2,7)Anthracenophane: synthesis and conformational studies. 615

Staab, H. A. Cycloarenes, a new class of aromatic com = pounds. IV. Attempts to synthesize cyclo[d.e.e.d.e.e. d.e.e.]nonakisbenzene and cyclo[d.e.d.e.d.e.d.e.d.e]de= cakisbenzene. 742

Stanoeva, E. Reactions of glutaconic and homophthalic anhydrides with imidates, imidoyl chlorides, and 1-chloroisoquinoline, 389

Steckhan, E. Oxidative deblocking of the 4-methoxy= benzyl thioether protecting group: application to the directed synthesis of polycystinyl peptides. 1563

Steffan, B. Antibiotics from Basidiomycetes, XIX Naematolin and naematolone, two caryophyllane derivatives from cultures of Hypholoma species (Agar = icales). 1332

Steffan, B. Antibiotics from basidiomycetes, XX. Syn= thesis of strobilurin A and revision of the stereochem = istry of natural strobilurins. 1616

Steglich, W. Antibiotics from Basidiomycetes, XIX. Naematolin and naematolone, two caryophyllane derivatives from cultures of Hypholoma species (Agar = icales). 1332

Steglich, W. Antibiotics from basidiomycetes, XX. Synthesis of strobilurin $A$ and revision of the stereo= chemistry of natural strobilurins. 1616

Steker, H. Synthesis of 2'-deoxyribofuranosides of $7 \mathrm{H}$-pyrrolo[2,3-d]pyrimidine: effect of the $\mathrm{C}-2$ sub $=$ stituents on the fluorescence. 1719

Stetter, H. Compounds with Urotropin structure, LX. Orthooxalic and orthocarbonic acid derivatives with adamantane structure. 1577

Stoffregen, A. Intramolecular addition of carbanions to anthraquinones. 306

Stoppa, H. Metal complexes with tetrapyrrole ligands, XXXV. Synthesis of further more or less sterically hindered 5,15-dialkyloctaethylporphodimethenes by reductive alkylation of octaethylporphyrinatozinc. 1259

Straehie, J. Syntinesis and structure of cyano(dihydrodi= benzo[b,i] $[1,4,8,11]$ tetraazacyclotetradecinato $)$ cobalt $=$ (III). 1791

Stumpp, M. Glycosyl imidates, 10. Glycosyl phosphates from glycosyl trichloroacetimidates. 680

Sucrow, $\mathbf{W}$. Enehydrazines, 37. Synthesis of a pyrazole analog of 7-aminomitosene. 1711

Suranyi, M. Synthesis of the pterocarpan constituents of Swartzia laevicarpa. 127

Sutter, M. A. Enantiomerically pure synthons from branched malates (correction). 407

Szabo, B. Synthesis of the pterocarpan constituents of Swartzia laevicarpa. 127

Takase, K. Multistep reversible redox systems, XXXIX Isomeric biazulenyls: UV/VIS spectroscopy, voltam= metry, and HMO energies. 1952

Tauer, M. L. Synthesis of new carboximidoyl chlorides and their reaction with nucleophiles. 564

Thielert, K. 7-Aroyl-1 H,7H-s-triazolo[1,2-a]-s-tria = zole-1,3(2H)-diones, a new class of compounds from 5-phenyloxazoles and 4-phenyl-4H-1,2,4-triazole-3, = 5-dione. 641

Thiemeyer, H. Lithium enolates of carbohydrates, 2. Axial $\alpha-C$-methylation and -hydroxymethylation of carbohydrate uloses. 1094

Todaro, L. J. Reactions of 1,4-pentadien-3-ones, 22 Synthesis and structure of the epimers of 3,5-diaryl-= 4-hydroxy-1,4-thiazinane 1,1-dioxides. 1013

Liebigs Ann. Chem. 1984
Toepert, M. Syntheses with nucleic acid constituents, X. Mass spectrometry of nucleotides, VII. Synthesis of deoxyoligonucleotide linker fragments for genetic engineering using improved preparative and analytical techniques. 835

Unger, F. M. Synthons of oligosaccharides, LII. Synthe= sis of disaccharides from 3-deoxy-D-manno-2-octulo $=$ sonic acid (KDO) and D-glucosamine. 1270

Unger, F. M. Synthons of oligosaccharides, LIII. Syn $=$ thesis of trisaccharides containing $3-$ deoxy-D-man $=$ no-2-octulosonic acid (KDO). 1288

Voelter, W. Kinetics, catalysis, and mechanism of the secondary reaction in the final phase of the formose reaction. 623

Voelter, W. Stereospecific syntheses of D-ossamine and D-tolyposamine. 636

Voges, K. P. Conformation of Boc-L-Ala-Aib-L-Ala- = $\mathrm{OMe}$ in the crystal and in solution. 1117

Von Deyn, W. Cyclitol reactions. X. Synthesis of enantiomerically pure pseudo- $\alpha-D-$ galactopyranose and pseudo- $\beta-D-$ mannopyranose. 433

Von Schnering, H. G. Structure of the $1: 1$ adducts of aryl isocyanides to 4-benzoyl-5-phenylfuran-2,3-= dione and their products with nucleophiles. Novel rearrangements of 5,5-disubstituted 4-methylenefu $=$ ran-2,3-diones. 1137

Vowinkel, E. A new method for the degradation of anthocyanidins, flavones, chalcones, and coumarins. 401

Vowinkel, E. The red membrane pigments of the peat moss Sphagnum rubellum. 1024

Wagner, P. Synthesis and carbon-13 NMR spectroscop= ic studies of bridgehead-substituted endo-bicyclo[3.= 3.1]nonan-3-ols and oxaadamantanes. 1981

Wahner, J. U. Chemistry of amino oximes, XVIII. The cyclocondensation of $(\mathrm{E})-\beta-($ chloroacetylamino) pro $=$ piophenone oxime derivatives. 1696

Wallmeyer, $M$. New sesquiterpene lactones and rosane derivatives from Trichogonia species. 162

Walz, B. A contribution to the structural assignment of positional isomers of bis-galacto and bis-manno crown ethers. 1046

Wamhoff, H. Reactions of uracils, 4. Some aspects of the chemistry of pyrido[2,3-d]pyrimidines. A nove s-triazolo $\left[4^{\prime}, 3^{\prime}: 1,6\right]$ pyrido[2,3-d]pyrimidine. 1653

Wanja, U. Metalloporphyrins in polymeric matrixes, micelles, and vesicles, V. 5-(1'-Methyl-4,4'-bipyridi= nium-1-yl)octaethylporphyrin dichloride, a meso-viol= ogenporphyrinate. 426

Wanner, K. T. Benzothiazoles by carbon-carbon cleav: age of $\alpha-[(2-$ nitrophenyl $)$ thio] ketones. 1100

Wanner, K. T. Pyrans, 100. 5,6-Dihydro-2H-pyran-3= $(4 \mathrm{H})$-one as a synthon for pyran-annulated hetero $=$ cyclic compounds. 1759

Wasmuth, D. Enantiomerically pure synthons from branched malates (correction). 407

Wassmuth, U. Trifluoromethyl-substituted pyrimidines from enamines and trifluoroacetonitrile. 991

Weber, B. Albomycins, II. Absolute configuration of the deferri form of the albomycins. 1408

Wegner, P. Synthesis of further eremophilane deriva= tives. 1785

Weinges, K. Chemistry and stereochemistry of iridoids, IV. Synthesis and $x$-ray structure analysis of $15-m e=$ thyl-12-epi-prostaglandin $\mathrm{F}_{2 \beta} .761$

Weiser, W. Reactions of enolic sugar derivatives, XVI. Synthesis of a diastereotopic proton probe $[(Z)-3,7-=$ anhydro-1,2-dideoxy-D-gluco-oct-2-enitol] for $\alpha$ and $\beta$-D-glucosidases. 1078

Weiser, W. Reactions of enolic sugar derivatives, XVI. Synthesis of a diastereotopic proton probe $[(Z)-3,7-=$ anhydro-1,2-dideoxy-D-gluco-oct-2-enitol] for $\alpha$ and $\beta-D$ glucosylases (correction). 1626

Weiss, M. M. Polyhydroxyamino compounds via diene synthesis with nitroso compounds. IX. trans-6-Azi= do-1,3-cyclohexadien-5-ol as educt for the synthesis of condurodiamine and streptamine isomers. 203

Weissmueller, J. Synthesis of the methyl ether of cardenolide-derived methylreductic acid starting from D-glucose. 66

Welzel, P. Properties of an (arylthiomethylene)cyclohex $=$ anone. 576

Wendisch, D. Constituents of Boraginaceae, 7. Anchu= soside-8 and -9 : two new triterpene saponins from Anchusa officinalis L. 1869 
Wieczorek, P. Synthesis of peptides with $\alpha, \beta$-dehy $=$ droamino acids, I. Synthesis of $\mathrm{N}$-(benzyloxycarbo $=$ nyl) and $\mathrm{N}$-(trifluoroacetyl) dipeptides of dehydroala = nine and dehydrophenylalanine. 920

Wiessler, M. Chemistry of nitrosamines, IV. Syntheses of $\alpha-\mathrm{C}$-functionalized $\mathrm{N}$-nitrosodialkylamines: esters and ethers of 1-[(alkyl)(nitroso)amino]alcohols. 1468

Wiessler, $M$. Syntheses of $\alpha-C$-functionalized $N$-nitro dialkylamines: esters of [(alkyl)(nitro)amino]metha = nol and $1-[($ alkyl)(nitro)amino] ethanol. 1494

Winkeler, H. D. Synthesis and furanoside/pyranoside isomerization of 7-deaza-2'-deoxy-7-methylguano= sine. 708

Winkelmann, G. Iturin $A_{L}$ : structure and derivatives of a peptidolipid with a high content of $\mathrm{C}_{16}$-iturinic acids. 854

Winter, $\mathbf{W}$. Conformation of Boc-L-Ala-Aib-L-Ala-OMe in the crystal and in solution. 1117

Winter, W. Configuration and conformation of the nucleoside residues of the nikkomycins. 1216

Winterfeldt, E. Cyclopentenone derivatives. VII. The stereoselective synthesis of brefeldin precursors. 450

Winterfeldt, E. Cyclopentenone derivatives. VIII. Reactions with acetoxycyclopentenones, brefeldin-A cyclizations. 462

Winterfeldt, E. Cyclopentenone derivatives. IX. Enan = tioselective routes to brefeldin-A. 474

Witzel, H. Synthesis and properties of 2,2'-bipyridin-= 3-ols and -3,3'-diols. 1731

Wobig, D. Thiazole derivatives, VI. Synthesis of thiazolo[4,5-d]-v-triazin-7 $(6 \mathrm{H})$ - ones. 1994

Wolf, B. A new method for the degradation of antho= cyanidins, flavones, chalcones, and coumarins. 401

Wolf, $\mathbf{H}$. Dehydrogenation reactions with gallic acid esters. 929

Wolff, H. P. Syntheses of antimicrobial biscationic 2-(phenoxyphenyl)indoles and -1-benzofurans. 409

Wolter, B. Dehydrogenation reactions with gallic acid esters. 929

Wray, V. New constituents of Levisticum officinale Koch. 397

Yamamura, H. Reactions of 1,4-pentadien-3-ones, 22. Synthesis and structure of the epimers of 3,5-diaryl-4-hydroxy-1,4-thiazinane 1,1-dioxides. 1013

Yassin, S. Reactions with 2-methyl- and 2-styryl-4-= thiochromones. 186

Yassin, S. Carbonyl and thiocarbonyl compounds: reac $=$ tions of 4-chloroxanthione with diazoalkanes and compounds containing active hydrogen. 191

Yassin, S. Reactions of 4-chloro-9H-xanthene-9-thione with tetrachloro-o-benzoquinone. 196

Yun, K. Y. Syntheses with aliphatic dialdehydes XXXVIII. Synthesis and properties of cycloalkylmal = onaldehydes. 649

Zahran, M. Reactions with 2-methyl- and 2-styryl-4-= thiochromones. 186

Zdero, C. New sesquiterpene lactones and rosane deriva $=$ tives from Trichogonia species. 162

Zdero, C. New germacranolides, heliangolides, and elemanolides from Cronquistianthus chachapoyensis. 240

Zdero, C. Epoxycannabinolide and diterpenes with a new carbon skeleton from Villanova titicaensis. 250

Zdero, C. Heliangolides and trachylobane and villano= vane derivatives from Viguiera species. 495

Zdero, C. Pseudoguaianolides and other sesquiterpenes from Monactis macbridei. 503

Zechlin, L. Antibiotics from Basidiomycetes, XIX. Naematolin and naematolone, two caryophyllane derivatives from cultures of Hypholoma species (Agar = icales). 1332

Zeid, I. Reactions with 2-methyl-and 2-styryl-4-thio = chromones. 186

Zeid, I. Carbonyl and thiocarbonyl compounds: reac= tions of 4-chloroxanthione with diazoalkanes and compounds containing active hydrogen. 191

Zeid, I. Reactions of 4-chloro-9H-xanthene-9-thione with tetrachloro-o-benzoquinone. 196
Ziegler, E. Structure of the 1:1 adducts of aryl isocyan= ides to 4-benzoyl-5-phenylfuran-2,3-dione and their = products with nucleophiles. Novel rearrangements of 5,5-disubstituted 4-methylenefuran-2,3-diones. 1137

Zorzin, C. Antibiotics from gliding bacteria, XXIII. Stigmatellin A and B - two novel antibiotics from Stigmatella aurantiaca (Myxobacterales). 1883 


\title{
LIEBIGS ANNALEN DER CHEMIE
}

\author{
HERAUSGEGEBEN VON DER \\ GESELLSCHAFT DEUTSCHER CHEMIKER
}

JAHRGANG $1984 \cdot$ HEFT $11 \cdot$ SEITE $1759-1882$

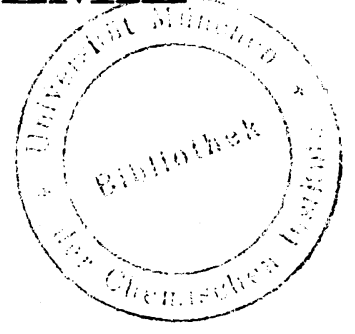

Dieses Heft wurde am 12. November 1984 ausgegeben

Pyrane, $100^{1)}$

\section{5,6-Dihydro-2H-pyran-3(4H)-on als Baustein zur Synthese pyrananellierter Heterocyclen}

\author{
Fritz Eiden* und Klaus Th. Wanner \\ Institut für Pharmazie und Lebensmittelchemie der Universität München, \\ Sophienstraße 10, D-8000 München 2
}

Eingegangen am 14. Februar 1984

\begin{abstract}
Während 5,6-Dihydro-2 $H$-pyran-3(4H)-on (3) sich mit ortho-substituierten Phenylcarbonylverbindungen nur in Einzelfällen regioselektiv zu pyrananellierten Heterocyclen umsetzt - z. B. zum Pyrano[2,3-b]chinolin 7c -, gelingt das besser mit dem aus 3 hergestellten Enamin 15d, dem Silylenolether 18 und dem daraus gewonnenen Lithiumenolat 14. Diese Pyranderivate mit 2,3oder 3,4-Doppelbindungen eignen sich zur gezielten Darstellung von 2- oder 4-substituierten 3-Pyranonen - z. B. 2, 21a, 21b, 23a-c, 26a-c, 31a-c, 32 sowie 35a-c - und von Pyrano[3,2-b]- oder $-[3,4-b]$ chinolinen, -chinolonen, -chromonen und -thiochromonen $6 \mathbf{a}$, $30 \mathbf{a}-\mathbf{c}$ und $38 \mathbf{a}-\mathbf{d}$.
\end{abstract}

Pyrans, 100 1). - 5,6-Dihydro-2H-pyran-3(4H)-one as a Building Unit for the Synthesis of Pyran-annulated Heterocyclic Compounds

Only in a few cases 5,6-dihydro- $2 H$-pyran-3(4H)-one (3) reacts regioselectively with orthosubstituted phenylcarbonyl compounds to form pyran-annulated heterocyclic compounds like the pyrano[3,2-b]quinoline 7c. Better results are obtained in reactions involving the enamine 15d derived from 3, the silyl enol ether 18 and the lithium enolate 14 derived from 18 . These pyran derivatives with 2,3- or 3,4-double bonds are well suited for successful synthesis of 2- or 4-substituted 3-pyranones such as 2, 21a, 21 b, 23a-c, 26a-c, 31a-c, 32, and 35a-c. They also allow to synthesize pyrano $[3,2-b]$ - or - $[3,4-b]$ quinolines, -quinolones, -chromones, and -thiochromones $6 a, 30 a-c, 38 a-d$.

Im Zusammenhang mit Untersuchungen über Struktur-Wirkungsbeziehungen bei pyrananellierten Heterocyclen haben wir geprüft, ob sich 5,6-Dihydro- $2 H$-pyran-3(4H)on $^{2)}$ (3) zur Darstellung solcher Systeme verwenden läßt und ob sich geeignete Syntheseverfahren regioselektiv führen lassen.

Liebigs Ann. Chem. 1984, 1759-1777

(c) Verlag Chemie GmbH, D-6940 Weinheim, 1984

$0170-2041 / 84 / 1111-1759 \$ 02.50 / 0$ 


\section{Reaktionen mit 5,6-Dihydro-2H-pyran-3(4H)-on}

Wir haben zunächst Reaktionen von 3 mit aromatischen Aldehyden, Aminoaldehyden und Aminoketonen untersucht. Mit Trimethoxybenzaldehyd (4a) entstand, je nach Art der zugesetzten Base, bevorzugt die 2,4-Bis(yliden)-Verbindung 1 oder das 2-YlidenDerivat 5; mit 2-Aminobenzaldehyd (4b) oder 2-Aminoacetophenon 4c erhielten wir Gemische der Pyrano[3,4-b]- und -[3,2-b]chinoline 6a und 7a bzw. 6b und 7b; nach Reaktion mit 2-Aminobenzophenon (4d) dagegen isolierten wir ausschließlich das $[2,3-b]$-Isomer $7 c$.<smiles>[R]c1cc(/C=C2\CCOCC2=O)cc([R])c1[R]</smiles><smiles>CC(C)C[13CH3]</smiles>
3<smiles>[R]c1cc(/C=C2\OCC/C(=C\c3cc([R])c([R])c([R])c3)C2=O)cc([R])c1[R]</smiles>

$$
1\left(\mathrm{R}=\mathrm{OCH}_{3}\right)
$$<smiles>CC(C)C</smiles><smiles>[R]C(=C)C([R])=C([X])C(C)C</smiles><smiles>[R]OC</smiles><smiles>CC(C)[13CH2][13CH3]</smiles><smiles>[R]c1cc(/C=C2\OCCCC2=O)cc([R])c1[R]</smiles><smiles>[R]c1c2c(nc3ccccc13)C(CC)OCC2CCCC</smiles>
\begin{tabular}{l|lll} 
4 & $\mathrm{X}$ & $\mathrm{R}^{1}$ & $\mathrm{R}^{2}$ \\
\hline a & $\mathrm{H}$ & $\mathrm{OCH}_{3}$ & $\mathrm{H}$ \\
b & $\mathrm{NH}_{2}$ & $\mathrm{H}$ & $\mathrm{H}$ \\
c & $\mathrm{NH}_{2}$ & $\mathrm{H}$ & $\mathrm{CH}_{3}$ \\
d & $\mathrm{NH}_{2}$ & $\mathrm{H}$ & $\mathrm{C}_{6} \mathrm{H}_{5}$
\end{tabular}

${ }^{1} \mathrm{H}-\mathrm{NMR}-$ Werte für $\mathbf{6 b}$

${ }^{1} \mathrm{H}-\mathrm{NMR}-$ Werte für $\mathbf{7 b}$

\begin{tabular}{l|l} 
& $\delta(J[\mathrm{~Hz}])$ \\
\hline A & $4.93(\mathrm{~s})$ \\
B & $4.07(\mathrm{~d}, J=5.5)$ \\
$\mathrm{C}$ & $2.97(t, J=5.5)$
\end{tabular}

\begin{tabular}{l|l|l}
$\mathbf{6}$ & $\mathrm{R}$ & $\mathbf{7}$ \\
\hline $\mathbf{a}$ & $\mathrm{H}$ & $\mathbf{a}$ \\
$\mathbf{b}$ & $\mathrm{CH}_{3}$ & $\mathbf{b}$ \\
& $\mathrm{C}_{6} \mathrm{H}_{5}$ & $\mathbf{c}$
\end{tabular}

\begin{tabular}{l|l} 
& $\delta(J[\mathrm{~Hz}])$ \\
\hline A & $3.15(t, J=6.5)$ \\
B & $1.7-2.3(\mathrm{~m})$ \\
C & $4.25(\mathrm{t}, J=5)$
\end{tabular}

Die [3,4-b]- und die [3,2-b]-Isomere 6 bzw. 7 lassen sich ${ }^{1} \mathrm{H}-\mathrm{NMR}$-spektroskopisch gut unterscheiden.

Wenig zufriedenstellend verliefen Umsetzungen von 3 mit 2-Amino-3-chromoncarbaldehyd (9). Mit Kaliumhydroxid/Ethanol entstand - in Umkehrung der Synthese 
von $9^{3)}$ - das 3-Carbonitril $\mathbf{1 0}^{4}$. Nach Zusatz von Salzsäure ließ sich nur das 2-Aminochromon $\mathbf{1 2}^{\text {5) }}$ isolieren, und erst beim Einsatz von Diazabicyclononen (DBN) erhielten wir das Kondensationsprodukt 11 (14\%) und daneben ein Gemisch von 11 und 8.<smiles>O=c1c2ccccc2oc2cc3c(nc12)CCCO3</smiles><smiles>O=c1c2ccccc2oc2cc3c(nc12)COCC3</smiles>

11

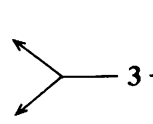<smiles>Nc1oc2ccccc2c(=O)c1C=O</smiles>

9<smiles>N#Cc1coc2ccccc2c1=O</smiles>

10<smiles>Nc1cc(=O)c2ccccc2o1</smiles>

12

Nach diesen unbefriedigenden Ergebnissen versuchten wir, die Pyran-Derivate 13- 18 möglichst regioselektiv darzustellen. Diese sollten dann mit elektrophilen und zur Cyclisierung geeigneten Reagenzien umgesetzt werden.

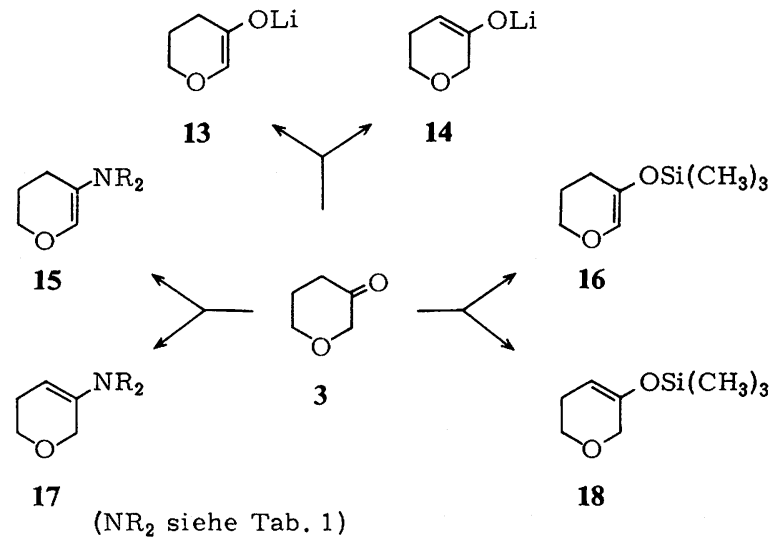

\section{Enamine}

Bei Umsetzungen von 3 mit den sekundären Aminen 19a-d nach bekanntem Verfahren ${ }^{6)}$ entstanden, je nach Amin, unterschiedliche Gemische der Enamine 15 und 17.

Die Isomerenverhältnisse der Enamine lassen sich mit Hilfe der ${ }^{1} \mathrm{H}-\mathrm{NMR}$-Spektren feststellen, und zwar durch Vergleich der Integrale des Olefin-Signals im Spektrum von 15 und eines $\mathrm{OCH}_{2}$-Signals im Spektrum von 17 (siehe Tab. 1 und Experimenteller Teil). Demnach entstehen mit Piperidin und Morpholin Enamingemische, die im wesentlichen aus $\mathbf{1 5} \mathbf{b}$ bzw. $\mathbf{1 5} \mathbf{d}$ bestehen und so für die Synthese brauchbar sind ${ }^{7}$. Umsetzungen von 15d ( + 9\% 17d) mit dem Trimethoxybenzaldehyd (4a) führten jedoch zu keinem isolierbaren Reaktionsprodukt. Nach der Reaktion mit 4-Nitrobenzaldehyd (20b) erhielten wir dagegen das 2-(4-Nitrobenzyliden)pyranon 21b in 27proz. Ausbeute. Daneben ließ sich eine geringe Menge einer Substanz isolieren, die sich als das be- 
Tab. 1. Umsetzungen von 3 mit den Aminen 19a-d zu den Enaminen 15a-d und 17a-d (Enaminverhältnisse). Die Verhältniswerte wurden nach Destillation ${ }^{1} \mathrm{H}$-NMR-spektroskopisch ermittelt.

\begin{tabular}{|c|c|c|}
\hline $3+\mathrm{HN}$ & & $4.76(\mathrm{~m})^{\mathrm{a})}$ \\
\hline $19 a-d$ & $15 a-d$ & $17 a-d$ \\
\hline & a (64) & a (36) \\
\hline b & b (92) & b (8) \\
\hline & c $(60)$ & c $(40)$ \\
\hline d $\mathrm{HN}$ & d (91) & d (9) \\
\hline
\end{tabular}

merkenswert stabile 4-Nitrobenzyliden-Enamin 22 identifizieren ließ, und die mit Salzsäure zum 4-(4-Nitrobenzyliden)tetrahydropyranon $23 \mathbf{b}$ hydrolysiert werden konnte. Bei Umsetzung von 15d (+9\% 17d) mit 2-Nitrobenzaldehyd (20a) erhielten wir das 2-Nitrobenzyliden-Derivat 21a in nur noch 2proz. Ausbeute. Nach Reaktion von 15d (+ 9\% 17d) mit 2-Aminobenzaldehyd (4b) ließ sich das Pyrano[3,2-b]chinolin 7a in 11 proz. Ausbeute isolieren, daneben erhielten wir aber auch $5 \%$ des Isomers $6 \mathbf{a}$.

Auch das Chromon 9 reagierte mit dem Enamingemisch 15d/17d; neben dem [3,2-b]-Isomer 8 (nach Isolierung 6\%) ließ sich 11 dünnschichtchromatographisch nachweisen.

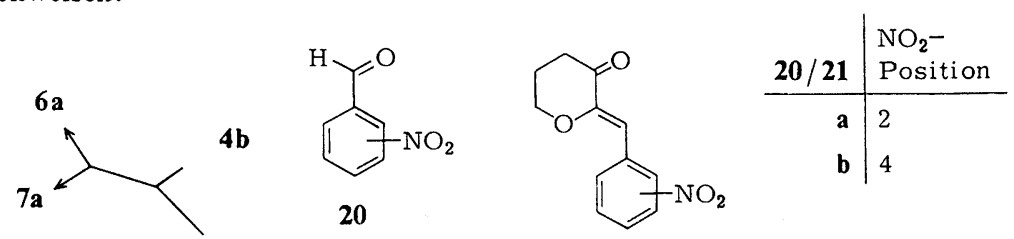

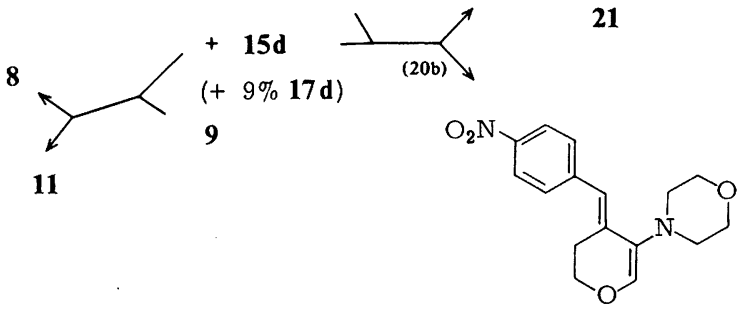

22

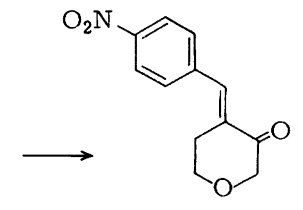

$23 b$

Bessere Ergebnisse wurden bei der Reaktion von 15d/17d mit Benzoylchlorid (24a) erzielt. Nach säulenchromatographischer Reinigung und Destillation erhielten wir in 29proz. Ausbeute das in 2-Stellung substituierte Pyranon 26a; daneben war das 4-Benzoylpyranon nur noch durch ein schwaches Signal bei $\delta=4.23 \mathrm{im}{ }^{1} \mathrm{H}-\mathrm{NMR}$ - 
Spektrum nachweisbar. Erwartungsgemäß reagierte die $\beta$-Dicarbonylverbindung 26a mit Benzamidin (27) zum Pyranopyrimidin 28.

Nach der Reaktion von 15d/17d mit einem größeren Überschuß 24a bei höherer Temperatur isolierten wir zwei kristalline Substanzen. Spektren und Analysen zufolge ließen sich die Verbindungen als Enolester des 2-Benzoylpyranons 25a, sowie als Benzoesäureester 29 des 1,5-Dihydroxy-2-pentanons identifizieren. Die Bildung von 29 kann man sich durch Einwirkung eines Benzoat-Ions auf das protonierte Enamin 15d vorstellen, wobei der Angriff des Anions in 2-Stellung erfolgt.

Das Gemisch 15d/17d reagierte mit der zweifachen Menge 2-Nitrobenzoylchlorid (24b) zum Enolester 25b (56\%). Vorsichtige Hydrolyse führte dann zum 2-Acylpyranon $26 \mathrm{~b}$.

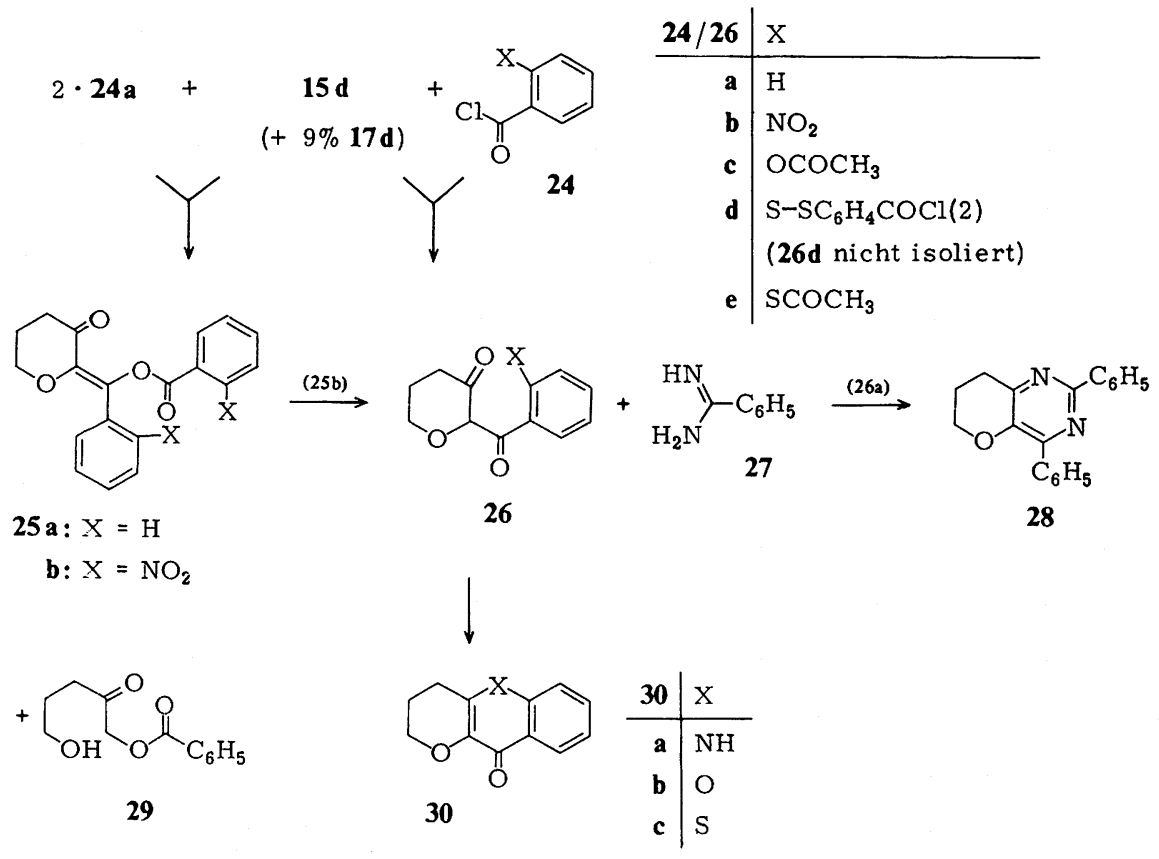

Nach Reaktion von Acetylsalicylsäurechlorid (24c) mit dem 15d/17d-Gemisch ließ sich das 2-Acylpyranon 26c rein gewinnen; die Umsetzung von Acetylthiosalicylsäurechlorid (24e) mit 15d/17d führte dagegen zu keinem isolierbaren Reaktionsprodukt. Bei Reaktion mit dem Disulfid 24d erhielten wir jedoch nach Säulenchromatographischer Trennung eine Substanz, die sich als Benzothiopyrano[3,2-b]pyran 30c identifizieren ließ; hier hat wahrscheinlich die Disulfidgruppe eines zuerst gebildeten (nicht isolierten) 2-Acyl-Derivates - des Enamins von 26d - mit der Enamindoppelbindung reagiert ${ }^{8)}$.

Es gelang dann auch, die 2-Acylpyranone 26b und 26c zu cyclisieren: 26b ließ sich durch Reduktion mit Zinn(II)-chlorid in das Pyrano[3,2-b]chinolon 30a überführen, 26c bildete mit methanolischer Chlorwasserstofflösung das Pyrano[3,2-b]benzopyranon $30 \mathrm{~b}$. 


\section{Silylenolether}

In Analogie zu einer von House ${ }^{9)}$ angegebenen Methode erhitzten wir 3 mit Trimethylsilylchlorid und Triethylamin in Dimethylformamid. Nach 45 Stunden war ein Gemisch der isomeren Silylenolether 16 und 18 im Verhältnis 31:69 entstanden. Damit war jedoch die Gleichgewichtslage noch nicht erreicht, bei längerem Erhitzen nahm der Anteil an 16 zu. Die Analyse gelingt eindeutig ${ }^{1} \mathrm{H}-\mathrm{NMR}$-spektroskopisch mit Hilfe der Olefinsignale von $16(\delta=6.27, \mathrm{t})$ und $18(\delta=4.78-5.05, \mathrm{~m})$. Im Gegensatz zu der thermodynamisch kontrollierten Reaktionsführung entstand nach Austausch von Dimethylformamid durch das niedriger siedende Tetrahydrofuran als Lösungsmittel ausschließlich 18 in 79proz. Ausbeute ${ }^{10}$.

Erhitzen von 18 in Dimethylformamid unter Zusatz von Triethylammoniumchlorid führte in zunehmendem Maße zur Bildung von 16. Bei Silylierung von 3 entsteht demnach zunächst kinetisch kontrolliert der Silylenolether 18, der sich dann unter thermodynamischen Bedingungen in $\mathbf{1 6}$ umlagert.

Nach Reaktion von 18 mit den Aldehyden 20a-c unter Zusatz von Titan(IV)chlorid erhielten wir die erwarteten Aldoladdukte 31a-c (dem ${ }^{1} \mathrm{H}-\mathrm{NMR}$-Spektrum zufolge lag nach der Reinigung von 31 b nur ein Diastereomer vor). Erhitzen von $31 \mathbf{a}-\mathbf{c}$ in Benzol/4-Toluolsulfonsäure (für 31c Polyphosphorsäure) führte zu den BenzylidenDerivaten $23 \mathbf{a}-\mathbf{c}$.

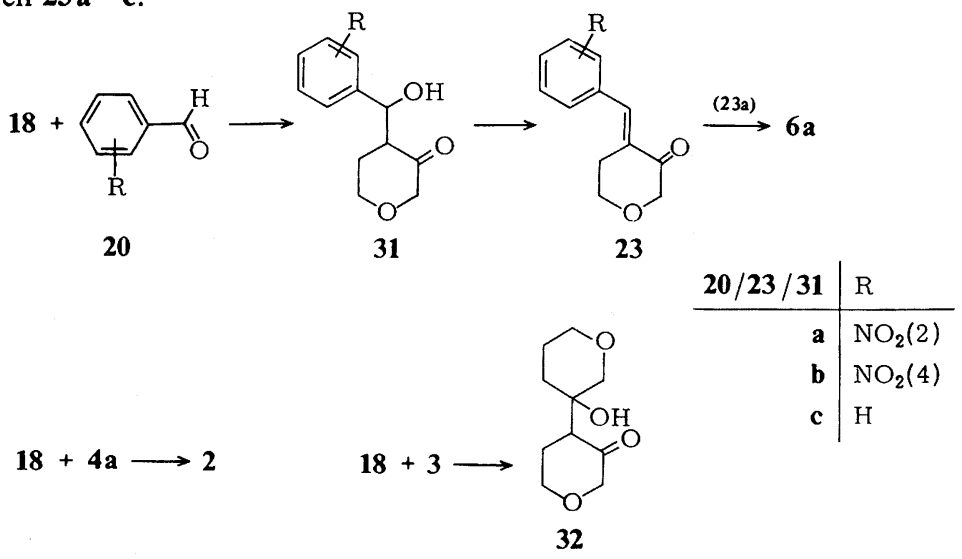

Die Reaktion von 18 mit dem Aldehyd $4 a$ führte direkt zum 4-Benzyliden-Derivat 2 , und mit dem Pyranon 3 zum Addukt 32.

Während bei Umsetzung des Enamin-Gemisches 15d/17d mit 2-Aminobenzaldehyd (4b) in mäßiger Ausbeute ein Gemisch der Pyranochinoline 6a und 7a entstand, führte die Natriumdithionit-Reduktion von 31a in guter Ausbeute ausschließlich zum Pyrano$[3,4-b]$ chinolin $6 \mathbf{a}$.

\section{Lithiumenolate}

Um die in der Literatur beschriebenen Schwierigkeiten bei Umsetzungen von Silylenolethern mit Säure-Derivaten ${ }^{11)}$ zu umgehen, setzten wir nach bekanntem Verfahren $^{12)} 18$ mit Methyllithium um und erhielten in guter Ausbeute das Lithiumenolat 14. 
Die Reaktion von 14 mit Benzoylchlorid (24a) lieferte nach Reinigung das 4-Benzoyl3-pyranon 35a in 59proz. Ausbeute. Daneben ließ sich in geringer Menge ein zweites Reaktionsprodukt isolieren, dessen ${ }^{1} \mathrm{H}$-NMR-Spektrum neben einem Pyranon-Teil eine $\mathrm{CH}_{2}-\mathrm{O}-\mathrm{CH}_{2} \mathrm{CH}_{2} \mathrm{CH}_{2}-\mathrm{COC}_{6} \mathrm{H}_{5}$-Gruppierung erkennen läßt. Wir haben dem Nebenprodukt deshalb die Struktur 36a zugeordnet und die Bildung durch Angriff des Anions von 14 auf die $\beta$-Dicarbonylverbindung 35a erklärt; dabei wird ein Pyranring aufgespalten.

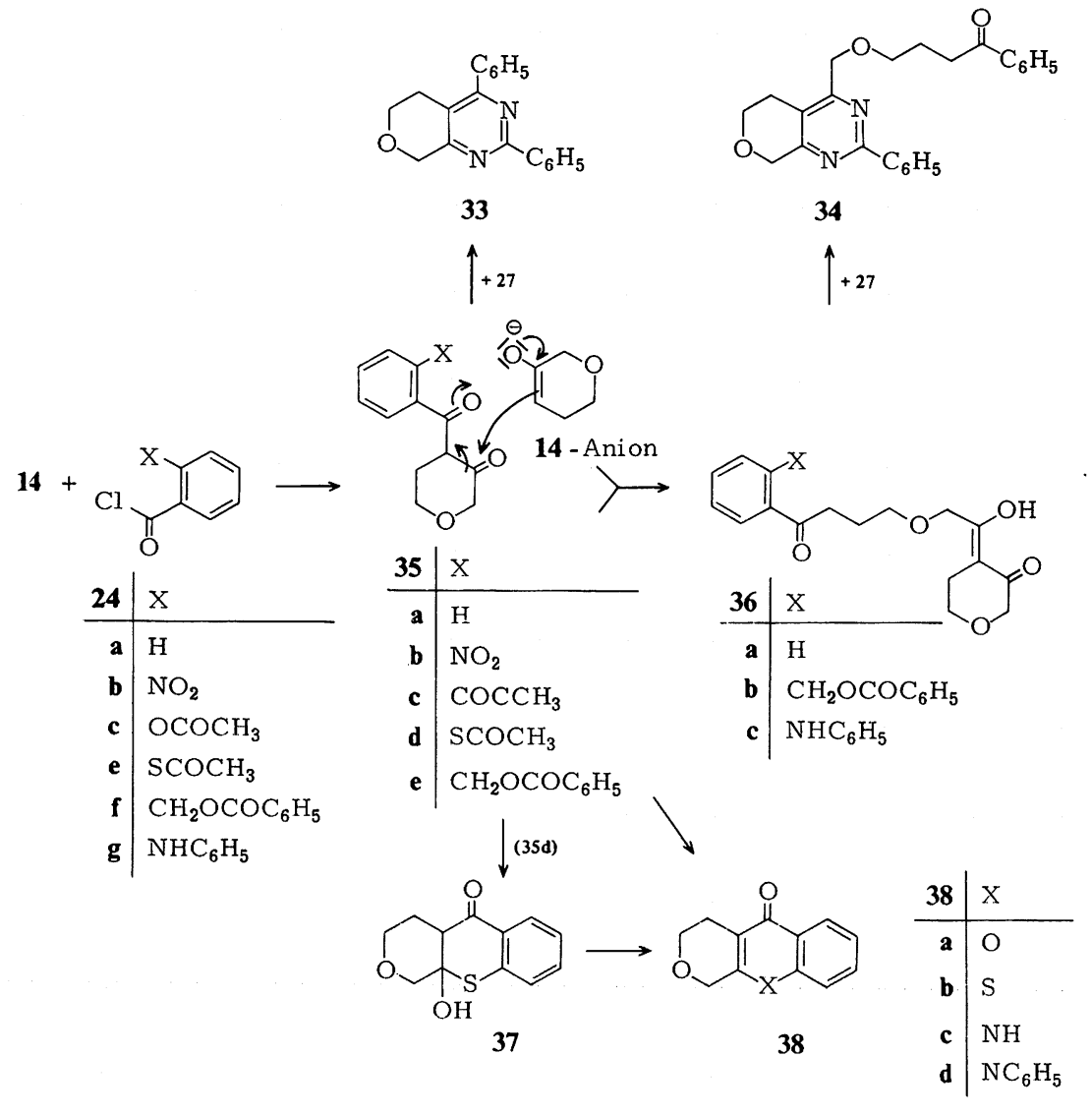

Auch mit den Benzoylchlorid-Derivaten 24 b, $\mathbf{c}$ und e reagierte 14 unter Bildung der 4-substituierten Pyranone 35b, $\mathbf{c}$ und $\mathbf{d}$. Bei Umsetzung mit 24f wurde neben 35e der Virylalkohol $36 \mathrm{~b}$ isoliert, mit 24e entstand neben 35d das Pyranobenzothiopyranon 37, und bei der Reaktion von $\mathbf{1 4}$ mit $\mathbf{2 4} \mathrm{g}$ erhielten wir direkt das Pyranochinolon 38d unc daneben 36c.

Die $\beta$-Dicarbonylverbindungen 35a und 36a ließen sich mit Benzamidin (27) in die Pysanopyrimidine 33 und 34 überführen; 35c, d und 37 bildeten bei Einwirkung von me:hanolischer Chlorwasserstofflösung die Pyrano[3,4-b]benzopyran- bzw. -thioLiesigs Ann. Chem. 1984 
pyran-Derivate 38a, b. Das Pyrano[3,4- $b$ ]chinolon 38c entstand bei der Reduktion des Nitro-Derivats $35 \mathbf{b}$ mit Natriumdithionit.

Dem Fonds der Chemischen Industrie danken wir für die finanzielle Unterstützung unserer Untersuchungen, Frau A. Kärtner für die engagierte Mitarbeit beim Experimentieren.

\section{Experimenteller Teil}

Schmelzpunkte (nicht korrigiert): Schmelzpunktsbestimmungsapparat nach Dr. Tottoli und Opfer-Schaum-Gerät. - ${ }^{1}$ H-NMR-Spektren: T-60 und A-60 (Varian); $\delta$-Werte, TMS als interner Standard. - ${ }^{13}$ C-NMR-Spektren: WP 80 (Bruker), $\delta$-Werte, TMS als interner Standard. Massenspektren: CH 7 (Varian). - IR-Spektren: Acculab 6 (Beckman). - IR-Spektren von Flüssigkeiten als Film, von Feststoffen als KBr-Preßling. - CHN-Analysen: CHN-Analysator, Modell 185 (Hewlett-Packard); CHN-Rapid (Heraeus). - Dünnschichtchromatographie: DC-Fertigplatten Kieselgel $60 \mathrm{~F}_{254}$ (Fa. Merck, Nr. 5715). - Präparative Schichtchromatographie: PSC-Fertigplatten Kieselgel $60 \mathrm{~F}_{254}$ (Fa. Merck, Nr. 5717), Schichtdicke $2 \mathrm{~mm}$. - Säulenchromatographie: Füllmaterial Kieselgel 60, Korngröße $0.063-0.200$ mm (Fa. Merck, Nr. 7734); Säulendurchmesser $28 \mathrm{~mm}$, Füllhöhe jeweils angegeben. - Schutzgas: Die Umsetzungen wurden unter Stickstoff durchgeführt.

5,6-Dihydro-2,4-bis(3,4,5-trimethoxybenzyliden)-2H-pyran-3(4H)-on (1): $3.92 \mathrm{~g} \mathrm{(20} \mathrm{mmol)} \mathrm{4a}$ wurden unter Erwärmen in $20 \mathrm{ml}$ Ethanol gelöst und unter Rühren mit $1.0 \mathrm{~g}(10 \mathrm{mmol}) 3 \mathrm{und} 4 \mathrm{ml}$ 5proz. ethanolischer Kalilauge versetzt. Nach 18stdg. Rühren bei Raumtemp. wurde abgekühlt, der entstandene Niederschlag abgesaugt und aus Essigester/Petrolether (10:1) umkristallisiert; gelbe Kristalle, Schmp. $147^{\circ} \mathrm{C}$, Ausb. $1.2 \mathrm{~g} \mathrm{(26 \% ).} \mathrm{-} \mathrm{IR:} 2935,1680,1615 \mathrm{~cm}^{-1}$. - ${ }^{1} \mathrm{H}-\mathrm{NMR}$ $\left(\mathrm{CDCl}_{3}\right): \delta=3.5-4.0(\mathrm{~m}, 2 \mathrm{H}), 3.95(\mathrm{~s}, 18 \mathrm{H}), 4.35(\mathrm{t}, J=6 \mathrm{~Hz}, 2 \mathrm{H}), 6.76(\mathrm{~s}, 2 \mathrm{H}), 6.8(2,1 \mathrm{H})$ $7.15(\mathrm{~s}, 2 \mathrm{H}), 7.73-7.90(\mathrm{~m}, 2 \mathrm{H})$. $-\mathrm{MS}: m / e=456\left(\mathrm{M}^{\oplus}\right)$.

$$
\mathrm{C}_{25} \mathrm{H}_{28} \mathrm{O}_{8}(456.5) \text { Ber. C } 65.78 \mathrm{H} 6.18 \text { Gef. C } 65.68 \mathrm{H} 6.16
$$

5,6-Dihydro-4-(3,4,5-trimethoxybenzyliden)-2H-pyran-3(4H)-on (2): Darstellung wie bei 31a beschrieben durch Umsetzung von $1.03 \mathrm{~g}(6 \mathrm{mmol}) \mathbf{1 8}, 1.29 \mathrm{~g}(6.6 \mathrm{mmol}) 4 \mathrm{a}$ und $1.25 \mathrm{~g}(6.6$ mmol) Titan(IV)-chlorid. Nach dem Zutropfen wurde $1 \mathrm{~h}$ bei $-78^{\circ} \mathrm{C}$ und $1 \mathrm{~h}$ bei Raumtemp. ge'rührt und anschließend hydrolysiert; Umkristallisation aus Essigester; hellgelbe Kristalle, Schmp. $134-136{ }^{\circ} \mathrm{C}$, Ausb. $0.3 \mathrm{~g}(18 \%)$. - IR: $1680,1600 \mathrm{~cm}^{-1}$. - ${ }^{1} \mathrm{H}-\mathrm{NMR}\left(\mathrm{CDCl}_{3}\right): \delta=3.02(\mathrm{td}$, $J=5.5,2 \mathrm{~Hz}, 2 \mathrm{H}), 3.70-4.02(2 \mathrm{H}), 3.83(\mathrm{~s}, 9 \mathrm{H}), 4.23(\mathrm{~s}, 2 \mathrm{H}), 6.67(\mathrm{~s}, 2 \mathrm{H}), 7.57(\mathrm{t}, J=2 \mathrm{~Hz}$, $1 \mathrm{H})$. - MS: $m / e=278\left(\mathrm{M}^{\oplus}\right)$.

$$
\mathrm{C}_{15} \mathrm{H}_{18} \mathrm{O}_{5} \text { (278.3) Ber. C } 64.74 \mathrm{H} 6.52 \text { Gef. C } 64.75 \mathrm{H} 6.49
$$

5,6-Dihydro-2-(3,4,5-trimethoxybenzyliden)-2H-pyran-3(4H)-on (5): Eine Mischung aus $2.94 \mathrm{~g}$

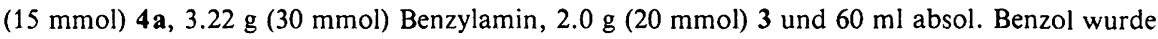
unter Rühren und mit aufgesetztem Wasserabscheider $30 \mathrm{~h}$ rückfließend erhitzt. Nach dem $\mathrm{Ab}$ kühlen wurde mit $70 \mathrm{ml}$ Diethylether verdünnt, mit $70 \mathrm{ml} 0.5 \mathrm{~N}$ Salzsäure versetzt und $1.5 \mathrm{~h}$ gerührt. Die organische Phase wurde abgetrennt, mit Wasser geschüttelt, getrocknet (Natriumsulfat) und eingeengt. Der Rückstand wurde aus Essigester/Petrolether umkristallisiert; gelbliche Kristalle, Schmp. $120-121^{\circ} \mathrm{C}$, Ausb. $1.0 \mathrm{~g}(24 \%)$. - IR: 2945, 1690, $1600 \mathrm{~cm}^{-1}$. - ${ }^{1} \mathrm{H}-\mathrm{NMR}$ $\left(\mathrm{CDCl}_{3}\right): \delta=2.03-2.50(\mathrm{~m}, 2 \mathrm{H}), 2.7(\mathrm{t}, J=6 \mathrm{~Hz}, 2 \mathrm{H}), 3.93(\mathrm{~s}, 9 \mathrm{H}), 4.33(\mathrm{t}, J=5 \mathrm{~Hz}, 2 \mathrm{H})$, $6.63(\mathrm{~s}, 1 \mathrm{H}), 7.1(\mathrm{~s}, 2 \mathrm{H})$. - MS: $m / e=278\left(\mathrm{M}^{\oplus}\right)$.

$$
\mathrm{C}_{15} \mathrm{H}_{18} \mathrm{O}_{5} \text { (278.3) Ber. C } 64.74 \mathrm{H} 6.52 \text { Gef. C } 64.58 \mathrm{H} 6.22
$$

3,4-Dihydro-1H-pyrano[3,4-b]chinolin (6a) und 3,4-Dihydro-2H-pyrano[3,2-b]chinolin (7a): A) Eine Mischung aus $0.67 \mathrm{~g}(5 \mathrm{mmol}) 4 \mathrm{~b}, 0.5 \mathrm{~g}(5 \mathrm{mmol}) 3$ und $10 \mathrm{ml}$ Ethanol wurde mit $1 \mathrm{ml}$ 
5proz. ethanolischer Kalilauge versetzt und $14 \mathrm{~h}$ bei Raumtemp. gerührt. Dann wurde i. Vak. eingedampft, mit Dichlormethan versetzt, mit Wasser geschüttelt und getrocknet (Natriumsulfat). Der nach Eindampfen i. Vak. verbleibende Rückstand $(0.9 \mathrm{~g})$ bestand $z \mathrm{u} 78 \%$ aus $6 \mathrm{a}$ und zu $22 \%$ aus 7a (NMR-spektroskopisch ermittelt). Nach Umkristallisation aus Essigester farblose Kristal-

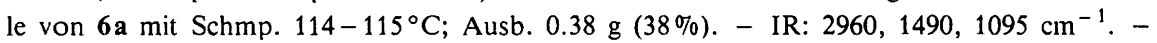
${ }^{1} \mathrm{H}-\mathrm{NMR}\left(\mathrm{CDCl}_{3}\right): \delta=3.11(\mathrm{t}, J=5.5 \mathrm{~Hz}, 2 \mathrm{H}), 4.13(\mathrm{t}, J=5.5 \mathrm{~Hz}, 2 \mathrm{H}), 5.06(\mathrm{~s}, 2 \mathrm{H})$, $7.30-8.16(\mathrm{~m}, 5 \mathrm{H})$. - MS: $m / e=185\left(\mathrm{M}^{\oplus}\right)$.

$$
\mathrm{C}_{12} \mathrm{H}_{11} \mathrm{NO}(185.2) \quad \text { Ber. C } 77.81 \mathrm{H} 5.99 \text { N } 7.56 \text { Gef. C } 77.88 \text { H } 5.98 \text { N } 7.62
$$

B) $1.82 \mathrm{~g}(15 \mathrm{mmol}) 4 \mathrm{~b}$ und $3.05 \mathrm{~g}(18 \mathrm{mmol}) \mathbf{1 5 d} / 17 \mathrm{~d}$ in $20 \mathrm{ml}$ absol. Toluol wurden unter Rühren und mit aufgesetztem Wasserabscheider $18 \mathrm{~h}$ rückfließend erhitzt. Dann wurde mit $0.5 \mathrm{~N}$ Salzsäure $(1 \times)$ und mit Wasser $(2 \times)$ geschüttelt, getrocknet (Natriumsulfat) und i. Vak. eingeengt. Der Rückstand wurde mittels DC gereinigt (Laufmittel: Essigester/Dichlormethan = $5: 95)$. Die Zone mit $R_{\mathrm{F}}=0.28$ wurde entfernt und mit Essigester extrahiert, der Extrakt i. Vak. eingedampft: farblose Kristalle von $7 \mathrm{a}$ mit Schmp. $71-73^{\circ} \mathrm{C}$, Ausb. $0.31 \mathrm{~g}(11 \%$, nicht umkristallisiert). - IR: $2960,1615,1600 \mathrm{~cm}^{-1}$. - ${ }^{1} \mathrm{H}-\mathrm{NMR}\left(\mathrm{CDCl}_{3}\right): \delta=2.02-2.24(\mathrm{~m}, 2 \mathrm{H}), 3.21(\mathrm{t}$, $J=6.5 \mathrm{~Hz}, 2 \mathrm{H}), 4.28(\mathrm{t}, J=5.2 \mathrm{~Hz}, 2 \mathrm{H}), 7.24-8.08(\mathrm{~m}, 5 \mathrm{H}) .-\mathrm{MS}: m / e=185\left(\mathrm{M}^{\oplus}\right)$.

$$
\mathrm{C}_{12} \mathrm{H}_{11} \mathrm{NO}(185.2) \text { Ber. C77.81 H } 5.99 \text { N 7.56 Gef. C 77.67 H 6.01 N 7.68 }
$$

6a konnte nach entsprechendem Verfahren aus der Zone mit $R_{\mathrm{F}}=0.12$ gewonnen werden (Ausb. $0.14 \mathrm{~g}, 5 \%$ ) sowie nach folgendem Verfahren.

C) $0.50 \mathrm{~g}(2 \mathrm{mmol}) 23 \mathrm{a}$, in $40 \mathrm{ml}$ Ethanol gelöst, wurden in der Siedehitze tropfenweise mit einer Lösung von $1.40 \mathrm{~g}(8 \mathrm{mmol})$ Natriumdithionit in $8 \mathrm{ml}$ Wasser versetzt. Nach 1stdg. Rückflußerhitzen wurde unlösliches abgetrennt, die Lösung i. Vak. eingeengt und der Rückstand mit $50 \mathrm{ml}$ Dichlormethan aufgeschlämmt. Es wurde filtriert und das Solvens i. Vak. entfernt; farblose Kristalle von 6a, Ausb. $0.25 \mathrm{~g}$ (67\%, nicht umkristallisiert).

3,4-Dihydro-5-methyl-1H-pyrano[3,4-b]chinolin (6b) und 3,4-Dihydro-10-methyl-2H-pyrano[3,2-b]chinolin (7b): $0.68 \mathrm{~g}$ (5 mmol) $4 \mathrm{c}$ und $1.5 \mathrm{~g}(15 \mathrm{mmol}) 3$, in $15 \mathrm{ml}$ absol. Benzol gelöst, wurden unter Rühren so lange mit Kaliumhydridsuspension versetzt, bis bei weiterer Zugabe nur noch eine geringe Wasserstoffentwicklung stattfand. Es wurde $5 \mathrm{~h}$ unter Rückfluß und $48 \mathrm{~h}$ bei Raumtemp. gerührt, dann nochmals $3(0.5 \mathrm{~g}, 5 \mathrm{mmol})$ und Kaliumhydridsuspension (wie oben) zugegeben und weitere $5 \mathrm{~h}$ rückfließend erhitzt. Nach dem Abkühlen wurde i. Vak. eingedampft, der Rückstand bei $10^{-4}$ Torr und $100-120^{\circ} \mathrm{C}$ Badtemp. destilliert und das Destillat mittels DC gereinigt (Laufmittel: Dichlormethan). Die blau fluoreszierenden Zonen bei $R_{\mathrm{F}}=0.11$ und $R_{\mathrm{F}}=0.22$ wurden entfernt und mit Essigester extrahiert. Der Extrakt der schneller wandernden Zone lieferte nach dem Eindampfen i. Vak. 7b als öligen Rückstand; Ausb. $0.37 \mathrm{~g} \mathrm{(37 \% ).} \mathrm{-}{ }^{1} \mathrm{H}-\mathrm{NMR}$ $\left(\mathrm{CDCl}_{3}\right): \delta=1.68-2.35(\mathrm{~m} ; 2 \mathrm{H}), 2.45(\mathrm{~s}, 3 \mathrm{H}), 3.15(\mathrm{t}, J=6.5 \mathrm{~Hz}, 2 \mathrm{H}), 4.25(\mathrm{t}, J=5 \mathrm{~Hz}$, $2 \mathrm{H}), 7.22-8.13(\mathrm{~m}, 4 \mathrm{H}) .7 \mathrm{~b}$ konnte nicht zur Kristallisation gebracht werden. Es wurde deshalb in $50 \mathrm{ml}$ Diethylether gelöst und durch Einleiten von Chlorwasserstoff als Hydrochlorid gefällt. Der Niederschlag wurde abgesaugt und aus Methanol umkristallisiert: farblose Kristalle, Schmp. $240^{\circ} \mathrm{C}$ (Zers.), Ausb. $0.17 \mathrm{~g}$. - IR: $3315,1545,1255 \mathrm{~cm}^{-1}$. - MS: $m / e=200\left(\mathrm{M}^{\oplus}-35\right)$. ${ }^{1} \mathrm{H}-\mathrm{NMR}\left(\mathrm{CDCl}_{3}\right): \delta=2.05-2.57(\mathrm{~m}, 2 \mathrm{H}), 2.73(\mathrm{~s}, 3 \mathrm{H}), 3.78(\mathrm{t}, J=6.5 \mathrm{~Hz}, 2 \mathrm{H}), 4.50(\mathrm{t}, J=$ $5 \mathrm{~Hz}, 2 \mathrm{H}), 7.75-8.23(\mathrm{~m}, 3 \mathrm{H}), 8.63-9.05(\mathrm{~m}, 1 \mathrm{H})$.

$$
\begin{array}{ll}
\mathrm{C}_{13} \mathrm{H}_{14} \mathrm{ClNO}(235.7) & \text { Ber. C } 66.24 \mathrm{H} 5.99 \mathrm{~N} 5.94 \mathrm{Cl} 15.04 \\
& \text { Gef. C } 65.99 \mathrm{H} 6.31 \mathrm{~N} 5.69 \mathrm{Cl} 15.78
\end{array}
$$

Der Extrakt der langsameren Zone wurde ebenfalls i. Vak. eingedampft $(0.25 \mathrm{~g}, 25 \%)$. Umkristallisation aus Essigester/Petrolether lieferte $6 \mathrm{~b}$ als farblose Kristalle mit Schmp. $113-114^{\circ} \mathrm{C}$; Ausb. $0.04 \mathrm{~g} \mathrm{(4 \% ).} \mathrm{-} \mathrm{IR:} \mathrm{2960,} \mathrm{1495,} 1095 \mathrm{~cm}^{-1}$. - ${ }^{1} \mathrm{H}-\mathrm{NMR}\left(\mathrm{CDCl}_{3}\right): \delta=2.55(\mathrm{~s}, 3 \mathrm{H}), 2.97$ 
$(\mathrm{t}, J=5.5 \mathrm{~Hz}, 2 \mathrm{H}), 4.07(\mathrm{t}, J=5.5 \mathrm{~Hz}, 2 \mathrm{H}), 4.93(\mathrm{~s}, 2 \mathrm{H}), 7.25-8.10(\mathrm{~m}, 4 \mathrm{H}) .-\mathrm{MS}: m / e=$ $199\left(\mathrm{M}^{\oplus}\right)$.

$$
\mathrm{C}_{13} \mathrm{H}_{13} \mathrm{NO}(199.3) \text { Ber. C 78.36 H6.58 N 7.03 Gef. C 78.30 H } 6.69 \text { N 7.26 }
$$

3,4-Dihydro-10-phenyl-2H-pyrano[3,2-b]chinolin (7c): $0.98 \mathrm{~g}(5 \mathrm{mmol})$ 4d wurden in $25 \mathrm{ml}$ absol. Benzol gelöst und mit $1.5 \mathrm{~g}(15 \mathrm{mmol}) 3$ versetzt. In die Mischung wurde bis zur Rotfärbung eine Kaliumhydridsuspension (in Öl) eingerührt. Es wurde noch $24 \mathrm{~h}$ bei Raumtemp. gerührt, dann in Vak. eingedampft und der Rückstand in Dichlormethan gelöst. Die organische Phasewurde mit Wasser gewaschen $(2 \times)$, getrocknet (Natriumsulfat) und i. Vak. eingeengt; aus Esssigester hellgelbe Kristalle mit Schmp. $174-176^{\circ} \mathrm{C}$, Ausb. 0.8 g (61 \%). - IR: 3045, 1475, $1127 \mathrm{~cm}^{-1}$. - ${ }^{1} \mathrm{H}-\mathrm{NMR}\left(\mathrm{CDCl}_{3}\right): \delta=1.93-2.46(\mathrm{~m}, 2 \mathrm{H}), 3.28(\mathrm{t}, J=6.7 \mathrm{~Hz}, 2 \mathrm{H}), 4.26(\mathrm{t}$, $J=5 \mathrm{~Hz}, 2 \mathrm{H}), 7.25-7.7(\mathrm{~m}, 8 \mathrm{H}), 7.9-8.17(\mathrm{~m}, 1 \mathrm{H}) .-\mathrm{MS}: m / e=261\left(\mathrm{M}^{\oplus}\right)$.

$$
\mathrm{C}_{18} \mathrm{H}_{15} \mathrm{NO}(261.3) \text { Ber. C } 82.73 \text { H } 5.79 \text { N } 5.36 \text { Gef. C 82.62 H 5.81 N } 5.51
$$

3,4-Dihydro-2H,6H-[1]benzopyrano[3,2-b]pyrano[2,3-e]pyridin-6-on (8): $0.95 \mathrm{~g}(5 \mathrm{mmol}) 9$ wurden in einer Mischung aus $1.02 \mathrm{~g} \mathrm{(6} \mathrm{mmol)} 15 \mathrm{~d} / \mathbf{1 7} \mathrm{d}$ und $75 \mathrm{ml}$ absol. Toluol suspendiert. Es wurde $36 \mathrm{~h}$ mit aufgesetztem Wasserabscheider rückfließend erhitzt und nach dem Erkalten von ungelöstem abgetrennt. Die Lösung wurde mit verd. Essigsäure $(1 x)$ und mit Wasser $(3 x)$ ausgeschüttelt, getrocknet (Natriumsulfat) und i. Vak. eingeengt. Fraktionierende Kristallisation aus Essigester lieferte in der zweiten Fraktion 8. Nach Umkristallisation aus Methanol hellgelbe Kristalle mit Schmp. $192^{\circ} \mathrm{C}$, Ausb. $0.07 \mathrm{~g}(6 \%)$. - IR: 2940, 1645, $1605 \mathrm{~cm}^{-1}$. $-{ }^{1} \mathrm{H}-\mathrm{NMR}$ $\left(\mathrm{CDCl}_{3}\right): \delta=2.02-2.50(\mathrm{~m}, 2 \mathrm{H}), 3.15(\mathrm{t}, J=6.5 \mathrm{~Hz}, 2 \mathrm{H}), 4.34(\mathrm{t}, J=5.2 \mathrm{~Hz}, 2 \mathrm{H})$, $7.35-7.95(\mathrm{~m}, 3 \mathrm{H}), 8.1(\mathrm{~s}, 1 \mathrm{H}), 8.37(\mathrm{dd}, 1 \mathrm{H}),-\mathrm{MS}: m / e=253\left(\mathrm{M}^{\oplus}\right)$.

$$
\mathrm{C}_{15} \mathrm{H}_{11} \mathrm{NO}_{3} \text { (253.3) Ber. C 71.14 H4.38 N } 5.53 \text { Gef. C 71.14 H 4.41 N } 5.45
$$

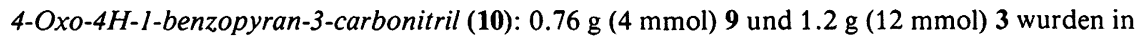
$60 \mathrm{ml} 2.5 \mathrm{proz}$. ethanolischer Kalilauge unter Rühren $12 \mathrm{~h}$ rückfließend erhitzt. Nach Verdampfen des Ethanols i. Vak. wurde mit Wasser versetzt, mit Ameisensäure neutralisiert, der entstandene Niederschlag abgesaugt und aus Ethanol umkristallisiert: farblose Kristalle, Schmp. $168^{\circ} \mathrm{C}$, Ausb. $0.35 \mathrm{~g}(51 \%)$. Zum Vergleich wurden $0.38 \mathrm{~g} \mathrm{(2} \mathrm{mmol)} 9$ in $30 \mathrm{ml} \mathrm{2.5proz}$. ethanolischer Kalilauge $12 \mathrm{~h}$ bei Raumtemp. gerührt. Nach Neutralisation mit $0.5 \mathrm{~N}$ Salzsäure wurde i. Vak. eingeengt und mit Wasser versetzt. Der Rückstand wurde aus Methanol umkristallisiert: farblose Kristalle, Schmp. $172-175^{\circ} \mathrm{C}$ (Lit. ${ }^{3)} 171-173.5^{\circ} \mathrm{C}$ ), Ausb. 0.15 g $(44 \%)$. - IR: 2250, $1662 \mathrm{~cm}^{-1}$. - MS: $m / e=171\left(\mathrm{M}^{\oplus}\right)$.

3,4-Dihydro-1H,11H-[1]benzopyrano[3,2-b]pyrano[4,3-e]pyridin-11-on (11): Eine Mischung bestehend aus $1.89 \mathrm{~g}(10 \mathrm{mmol}) 9,5 \mathrm{ml}$ 1,5-Diazabicyclo[4.3.0]non-5-en und $50 \mathrm{ml}$ Ethanol wur-

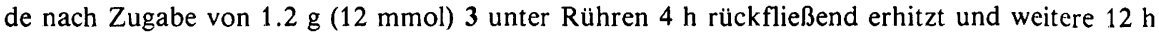
nach erneuter Zugabe von 3 (1.0 g, $10 \mathrm{mmol})$. Nach Verdampfen des Ethanols i. Vak. wurde mit Diethylether versetzt, dreimal mit Wasser gewaschen und die organische Phase nach Trocknen mit Natriumsulfat i. Vak. eingeengt. Der Rückstand wurde aus Ethanol fraktionierend kristallisiert.

1. Kristallfraktion: hellgelbe Kristalle von 11, Schmp. $196-197^{\circ} \mathrm{C}$, Ausb. $0.35 \mathrm{~g} \mathrm{(14 \% )}$. - IR: $2960,1665,1600 \mathrm{~cm}^{-1} .-{ }^{1} \mathrm{H}-\mathrm{NMR}\left(\mathrm{CDCl}_{3}\right): \delta=3.12(\mathrm{t}, J=5.5 \mathrm{~Hz}, 2 \mathrm{H}), 4.15(\mathrm{t}, J=5.5 \mathrm{~Hz}$, $2 \mathrm{H}), 4.94(\mathrm{~s}, 2 \mathrm{H}), 7.3-7.9(\mathrm{~m}, 3 \mathrm{H}), 8.35$ (dd, $J=1,4 \mathrm{~Hz}, 1 \mathrm{H}), 8.52(\mathrm{~s}, 1 \mathrm{H})$. $-\mathrm{MS}: m / e=$ $253\left(\mathrm{M}^{\oplus}\right)$.

$$
\mathrm{C}_{15} \mathrm{H}_{11} \mathrm{NO}_{3} \text { (253.3) Ber. C 71.14 H 4.38 N } 5.53 \text { Gef. C 71.08 H 4.37 N } 5.57
$$

2. Kristallfraktion: Isomerengemisch aus 8 und 11 im Verhältnis 1:2 (NMR-spektroskopisch ermittelt); Ausb. $0.2 \mathrm{~g} \mathrm{(8 \% ).}$ 
2-Amino-4H-1-benzopyran-4-on (12): Eine Lösung von $0.76 \mathrm{~g} \mathrm{(4} \mathrm{mmol)} 9$ und $1.0 \mathrm{~g}(10 \mathrm{mmol})$ 3 in $30 \mathrm{ml}$ absol. Methanol wurde mit Chlorwasserstoff gesättigt, rückfließend erhitzt und $12 \mathrm{~h}$ bei Raumtemp. gerührt. Das Lösungsmittel wurde i. Vak. verdampft und der Rückstand mit Wasser versetzt. Der nach Neutralisation mit $0.5 \mathrm{~N}$ Salzsäure entstandene Niederschlag wurde abgetrennt und aus Ethanol umkristallisiert: blaßgelbe Kristalle, Schmp. $268^{\circ} \mathrm{C}$ (Zers.) (Lit. ${ }^{5)}$ $275^{\circ} \mathrm{C}$, Zers.), Ausb. $0.4 \mathrm{~g}(62 \%)$. - IR: $3300,3100,1645,1610,1545 \mathrm{~cm}^{-1}$. MS: $m / e=161$ $\left(\mathrm{M}^{\oplus}\right)$.

$\mathrm{C}_{9} \mathrm{H}_{7} \mathrm{NO}_{2}(161.2)$ Ber. C67.08 H 4.38 N 8.69 Gef. C $66.97 \mathrm{H} 4.28$ N 8.67

Lithium-(5,6-dihydro-2H-pyran-3-olat)-Lösung (14): Eine Mischung aus $1.72 \mathrm{~g}(10 \mathrm{mmol}) 18$ und $30 \mathrm{ml}$ absol. Tetrahydrofuran wurde mit $10 \mathrm{mmol}$ Methyllithiumlösung ( $1.6 \mathrm{M}$ in Ether) versetzt und $1.5 \mathrm{~h}$ bei Raumtemp. gehalten. Die Lösung wurde i. Vak. $\left(10^{-2} \mathrm{Torr}\right)$ bei $0^{\circ} \mathrm{C}$ auf ein Drittel bis zur Hälfte des Volumens eingeengt, auf $-78^{\circ} \mathrm{C}$ abgekühlt und mit $15 \mathrm{ml}$ absol. Toluol verdünnt.

1-(5,6-Dihydro-4H-pyran-3-yl)pyrrolidin (15a) und 1-(5,6-Dihydro-2H-pyran-3-yl)pyrrolidin (17 a): $15.0 \mathrm{~g}(150 \mathrm{mmol}) 3,12.8 \mathrm{~g}(180 \mathrm{mmol}) 19 \mathrm{a}$ und $0.17 \mathrm{~g}(1 \mathrm{mmol}) p$-Toluolsulfonsäure wurden in $60 \mathrm{ml}$ absol. Benzol unter Rühren mit aufgesetztem Wasserabscheider $17 \mathrm{~h}$ rückfließend erhitzt. Die Lösung wurde i. Vak. fraktionierend destilliert: farblose Flüssigkeit, Sdp. $101-106^{\circ} \mathrm{C} /$ 10 Torr, Ausb. $22.5 \mathrm{~g}(98 \%)$. - IR: $2960,1645,1130 \mathrm{~cm}^{-1}$. - ${ }^{1} \mathrm{H}-\mathrm{NMR}\left(\mathrm{CDCl}_{3}\right): \delta=1.6-2.37$ $(\mathrm{m}, 0.64 \times 8 \mathrm{H}$ und $0.36 \times 6 \mathrm{H}), 2.53-3.07(\mathrm{~m}, 0.64 \times 4 \mathrm{H}$ und $0.36 \times 4 \mathrm{H}), 3.55-3.90(\mathrm{~m}$, $0.64 \times 2 \mathrm{H}$ und $0.36 \times 2 \mathrm{H}), 3.90-4.38(\mathrm{~m}, 0.36 \times 3 \mathrm{H}, 17 \mathrm{a}), 5.86(\mathrm{~s}, 0.64 \times 1 \mathrm{H}, 15 \mathrm{a}) .-\mathrm{MS}$ : $m / e=153\left(\mathrm{M}^{\oplus}\right)$.

$$
\mathrm{C}_{9} \mathrm{H}_{15} \mathrm{NO}(153.2) \text { Ber. C } 70.55 \text { H } 9.87 \text { N9.14 Gef. C } 70.50 \text { H } 9.87 \text { N } 9.00
$$

1-(5,6-Dihydro-4H-pyran-3-yl)piperidin (15b) und 1-(5,6-Dihydro-2H-pyran-3-yl)piperidin (17b): Herstellung wie bei $15 \mathrm{a} / 17 \mathrm{a}$ aus $5.0 \mathrm{~g}(50 \mathrm{mmol}) 3 \mathrm{und} 4.7 \mathrm{~g}(55 \mathrm{mmol}) \mathbf{1 9}$ b; $30 \mathrm{ml}$ absol. Benzol, Reaktionsdauer $16 \mathrm{~h}$; farblose Flüssigkeit, Sdp. $106-108^{\circ} \mathrm{C} / 10 \mathrm{Torr}$, Ausb. $6.0 \mathrm{~g}$ (72\%). - IR: 2925, 1645, $1145 \mathrm{~cm}^{-1}$. - ${ }^{1} \mathrm{H}-\mathrm{NMR}\left(\mathrm{CDCl}_{3}\right): \delta=1.28-2.33(\mathrm{~m}, 0.92 \times 10 \mathrm{H}+$ $0.08 \times 8 \mathrm{H}), 2.43-2.87(\mathrm{~m}, 0.92 \times 4 \mathrm{H}+0.08 \times 2 \mathrm{H}), 3.83(\mathrm{t}, 0.92 \times 2 \mathrm{H}, \mathbf{1 5 b}$, darunter Signal der $\mathrm{OCH}_{2}$-Gruppe von $\left.17 \mathrm{~b}\right), 4.13(\mathrm{~m}, 0.08 \times 2 \mathrm{H}, 17 \mathrm{~b}), 4.76(\mathrm{t}, 0.08 \times 1 \mathrm{H}, 17 \mathrm{~b}), 6.03(\mathrm{~s}, 0.92 \times$ $1 \mathrm{H}, \mathbf{1 5 b})$. - MS: $m / e=167\left(\mathrm{M}^{\oplus}\right)$.

\section{$\mathrm{C}_{10} \mathrm{H}_{17} \mathrm{NO}(167.3)$ Ber. C71.81 H 10.24 N 8.37 Gef. C 71.74 H 10.20 N 8.45}

1-(5,6-Dihydro-4H-pyran-3-yl)azepan (15c) und 1-(5,6-Dihydro-2H-pyran-3-yl)azepan (17c): Herstellung wie bei $15 \mathrm{a} / 17 \mathrm{a}$ angegeben aus $5.0 \mathrm{~g}(50 \mathrm{mmol}) 3$ und $4.96 \mathrm{~g}(55 \mathrm{mmol}) 19 \mathrm{c} ; 30 \mathrm{ml}$ absol. Benzol, Reaktionsdauer $20 \mathrm{~h}$; farblose Flüssigkeit, Sdp. $128-131{ }^{\circ} \mathrm{C}$, Ausb. $5.8 \mathrm{~g} \mathrm{(64 \% )}$. IR: 2920, 1640, $1135 \mathrm{~cm}^{-1}$. $-{ }^{1} \mathrm{H}-\mathrm{NMR}\left(\mathrm{CDCl}_{3}\right): \delta=1.33-2.40(\mathrm{~m}, 0.6 \times 12 \mathrm{H}$ und $0.4 \times$ $10 \mathrm{H}), 2.72-3.25(\mathrm{~m}, 0.6 \times 4 \mathrm{H}$ und $0.4 \times 4 \mathrm{H}), 3.53-3.92(\mathrm{~m}, 0.6 \times 2 \mathrm{H}$ und $0.4 \times 2 \mathrm{H}), 4.18$ $(\mathrm{m}, 0.4 \times 2 \mathrm{H}, 17 \mathrm{c}), 4.37(\mathrm{t}, 0.4 \times 1 \mathrm{H}, 17 \mathrm{c}), 5.95(\mathrm{~s}, 0.6 \times 1 \mathrm{H}, 15 \mathrm{c}) .-\mathrm{MS}: m / e=181\left(\mathrm{M}^{\oplus}\right)$.

\section{$\mathrm{C}_{11} \mathrm{H}_{19} \mathrm{NO}(181.3) \quad$ Ber. C 72.88 H 10.56 N 7.73 Gef. C $72.81 \mathrm{H} 10.50$ N 7.72}

4-(5,6-Dihydro-4H-pyran-3-yl)morpholin (15d) und 4-(5,6-Dihydro-2H-pyran-3-yl)morpholin (17d): Herstellung wie bei $15 \mathrm{a} / 17 \mathrm{a}$ angegeben aus $15.0 \mathrm{~g}(150 \mathrm{mmol}) 3$ und $14.37 \mathrm{~g}(165 \mathrm{mmol})$

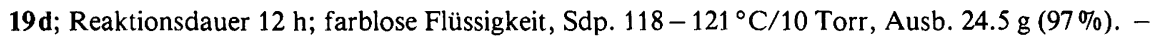
IR: $2850,1660,1455 \mathrm{~cm}^{-1} .-{ }^{1} \mathrm{H}-\mathrm{NMR}\left(\mathrm{CDCl}_{3}\right): \delta=1.57-2.33(\mathrm{~m}, 0.91 \times 4 \mathrm{H}$ und $0.09 \times$ $2 \mathrm{H}), 2.5-2.85(\mathrm{~m}, 0.91 \times 4 \mathrm{H}$ und $0.09 \times 4 \mathrm{H}), 3.52-3.92(\mathrm{~m}, 0.91 \times 6 \mathrm{H}$ und $0.09 \times 6 \mathrm{H})$, $4.10(\mathrm{~m}, 0.09 \times 2 \mathrm{H}, 17 \mathrm{~d}), 4.76(\mathrm{t}, 0.09 \times 1 \mathrm{H}, 17 \mathrm{~d}), 6.03(\mathrm{~s}, 0.91 \times 1 \mathrm{H}, 15 \mathrm{~d}) .-\mathrm{MS}: m / e=$ $169\left(\mathrm{M}^{\oplus}\right)$.

$$
\mathrm{C}_{9} \mathrm{H}_{15} \mathrm{NO}_{2} \text { (169.2) Ber. C } 63.88 \mathrm{H} 8.98 \mathrm{~N} 8.28 \text { Gef. C63.71 H 8.76 N 8.23 }
$$

3,4-Dihydro-5-trimethylsilyloxy-2H-pyran (16) und 5,6-Dihydro-3-trimethylsilyloxy-2H-pyran (18): A) Eine Mischung aus $15.0 \mathrm{~g}$ (150 mmol) 3, $19.6 \mathrm{~g} \mathrm{(180} \mathrm{mmol)} \mathrm{Chlortrimethylsilan,} 36.4 \mathrm{~g}$ 
(360 mmol) Triethylamin und $60 \mathrm{ml}$ absol. $N, N$-Dimethylformamid wurde $45 \mathrm{~h}$ rückfließend erhitzt. Überschüssiges Chlortrimethylsilan wurde abdestilliert und die DMF-Lösung zweimal mit Pentan $(200 \mathrm{ml} ; 50 \mathrm{ml})$ extrahiert. Die vereinigten Extrakte wurden zweimal mit kaltem Wasser gewaschen, getrocknet (Natriumsulfat) und i. Vak. fraktionierend destilliert: farblose Flüssigkeit, Sdp. $30.5-32.0^{\circ} \mathrm{C} / 2$ Torr, Ausb. $20.4 \mathrm{~g}(79 \%), 16: 18=31: 69$ [ ${ }^{1} \mathrm{H}$-NMR-spektroskopisch mit den Signalen bei $\delta=6.27(\mathrm{t}, J=1.5 \mathrm{~Hz}$, Olefinprotonen von 16$)$ und $4.78-5.05$ (m, Olefinproton von 18) ermittelt].

B) Wie unter A) angegeben wurden $3.5 \mathrm{~g}(35 \mathrm{mmol}) 3,5.70 \mathrm{~g}(52.5 \mathrm{mmol})$ Chlortrimethylsilan und $7.79(77 \mathrm{mmol})$ Triethylamin in $14 \mathrm{ml}$ absol. $N, N$-Dimethylformamid erhitzt. Probenentnahme und Bestimmung der 16: 18-Relation ( ${ }^{1} \mathrm{H}-\mathrm{NMR}$-spektroskopisch) erfolgte nach $41 \mathrm{~h}$ (16:18 = $15: 85), 47 \mathrm{~h}(\mathbf{1 6 : 1 8}=25: 75)$ und $94 \mathrm{~h}(\mathbf{1 6}: \mathbf{1 8}=65: 35)$.

C) $2.58 \mathrm{~g} \mathrm{(15} \mathrm{mmol)} 18$ und $2.06 \mathrm{~g}(15 \mathrm{mmol})$ Triethylamin-hydrochlorid wurden in $10 \mathrm{ml}$ absol. $N, N$-Dimethylformamid rückfließend erhitzt. Probenentnahme und Bestimmung der 16: 18-Relation $\left({ }^{1} \mathrm{H}\right.$-NMR-spektroskopisch) erfolgte nach $1 \mathrm{~h}(\mathbf{1 6 : 1 8}=41: 69), 2 \mathrm{~h}(\mathbf{1 6 : 1 8}=54: 46)$ und $3 \mathrm{~h}$ (16: $18=64: 36)$.

5,6-Dihydro-3-trimethylsilyloxy-2H-pyran (18): $30.0 \mathrm{~g}(300 \mathrm{mmol})$ 3, $81.48 \mathrm{~g}$ (750 mmol) Chlortrimethylsilan, $83.48 \mathrm{~g}(825 \mathrm{mmol})$ Triethylamin und $200 \mathrm{ml}$ absol. Tetrahydrofuran wurden $48 \mathrm{~h}$ rückfließend erhitzt. Das Lösungsmittel wurde i. Vak. verdampft, der Rückstand mit $300 \mathrm{ml}$ Pentan versetzt und filtriert. Das Filtrat wurde i. Vak. fraktionierend destilliert: farblose Flüssigkeit, Sdp. $67^{\circ} \mathrm{C} / 10$ Torr, Ausb. $40.9 \mathrm{~g}(79 \%)$ - IR: $2960,1680,1245 \mathrm{~cm}^{-1}$. - ${ }^{1} \mathrm{H}-\mathrm{NMR}$ $\left(\mathrm{CDCl}_{3}\right): \delta=0.20(\mathrm{~s}, 9 \mathrm{H}), 1.92-2.32(\mathrm{~m}, 2 \mathrm{H}), 3.67(\mathrm{t}, J=5.5 \mathrm{~Hz}, 2 \mathrm{H}), 3.78-3.95(\mathrm{~m}, 2 \mathrm{H})$, $4.78-5.05(\mathrm{~m}, 1 \mathrm{H})$. - MS: $m / e=172\left(\mathrm{M}^{\oplus}\right)$.

\section{$\mathrm{C}_{8} \mathrm{H}_{16} \mathrm{O}_{2} \mathrm{Si}$ (172.3) Ber. C $55.77 \mathrm{H} 9.36 \mathrm{Si} 16.30$ Gef. C 55.88 H $9.30 \mathrm{Si} 16.10$}

5,6-Dihydro-2-(2-nitrobenzyliden)-2H-pyran-3(4H)-on (21 a): $3.02 \mathrm{~g} \mathrm{(20} \mathrm{mmol)} \mathrm{20a,} 4.06 \mathrm{~g} \mathrm{(24}$ $\mathrm{mmol}) \mathbf{1 5 d} / \mathbf{1 7} \mathrm{d}$ und $40 \mathrm{ml}$ absol. Benzol wurden unter Rühren und mit aufgesetztem Wasserabscheider $14 \mathrm{~h}$ rückfließend erhitzt. Nach Zugabe von $10 \mathrm{ml} 6 \mathrm{~N}$ Salzsäure wurde $2 \mathrm{~h}$ bei Raumtemp. gerührt, die organische Phase abgetrennt, mit Wasser gewaschen und getrocknet (Natriumsulfat). Es wurde i. Vak. eingedampft und der Rückstand zweimal aus Methanol umkristallisiert: gelbe Kristalle, Schmp. $96-97.5^{\circ} \mathrm{C}$, Ausb. $0.1 \mathrm{~g}(2 \%)$. - IR: $1685,1598,1520 \mathrm{~cm}^{-1}$. ${ }^{1} \mathrm{H}-\mathrm{NMR}\left(\mathrm{CDCl}_{3}\right): \delta=1.91-2.43(\mathrm{~m}, 2 \mathrm{H}), 2.66(\mathrm{t}, 2 \mathrm{H}), 4.18(\mathrm{t}, J=5 \mathrm{~Hz}, 2 \mathrm{H}), 6.87(\mathrm{~s}, 1 \mathrm{H})$, $7.10-8.05(\mathrm{~m}, 4 \mathrm{H})$. - MS: $m / e=233\left(\mathrm{M}^{\oplus}\right)$.

$$
\mathrm{C}_{12} \mathrm{H}_{11} \mathrm{NO}_{4} \text { (233.2) Ber. C } 61.80 \mathrm{H} 4.75 \text { N } 6.01 \text { Gef. C } 61.78 \mathrm{H} 4.87 \text { N } 5.76
$$

5,6-Dihydro-2-(4-nitrobenzyliden)-2H-pyran-3(4H)-on (21 b) und 4-[5,6-Dihydro-4-(4-nitrobenzyliden)-4H-pyran-3-ylJmorpholin (22): $4.23 \mathrm{~g}(25 \mathrm{mmol}) \mathbf{1 5 d} / 17 \mathrm{~d}$ und $3.02 \mathrm{~g}$ (20 mmol) $20 \mathrm{~b}$ wurden in $40 \mathrm{ml}$ absol. Toluol gelöst. Dann wurde unter Rühren und mit aufgesetztem Wasserabscheider $18 \mathrm{~h}$ rückfließend erhitzt. Die abgekühlte Lösung wurde mit $8 \mathrm{ml} 6 \mathrm{~N}$ Salzsäure versetzt, 1 h gerührt, mit Wasser geschüttelt, getrocknet (Natriumsulfat) und i. Vak. eingeengt. Kristallisation aus Essigester lieferte ein Produktgemisch (aus gelben und roten Kristallen), das mit Aceton/ Methanol (1:1) vorsichtig extrahiert wurde. Es blieb ein roter Rückstand, der aus Essigester umkristallisiert wurde: rote Kristalle (22), Schmp. $172-173^{\circ} \mathrm{C}$, Ausb. $0.24 \mathrm{~g} \mathrm{(4 \% ).} \mathrm{-} \mathrm{IR:} 2940$, $1605,1580 \mathrm{~cm}^{-1}$. $-{ }^{1} \mathrm{H}-\mathrm{NMR}\left(\mathrm{CDCl}_{3}\right): \delta=2.61-3.0(\mathrm{~m}, 6 \mathrm{H}), 3.66-3.9(\mathrm{~m}, 4 \mathrm{H}), 4.02(\mathrm{t}, J=$ $5.5 \mathrm{~Hz}, 2 \mathrm{H}), 6.6(\mathrm{~s}, 1 \mathrm{H}), 6.86(\mathrm{~s}, 1 \mathrm{H}), 7.41(\mathrm{~d}, J=8.5 \mathrm{~Hz}, 2 \mathrm{H}), 8.22(\mathrm{~d}, J=8.5 \mathrm{~Hz}, 2 \mathrm{H})$. MS: $m / e=302\left(\mathrm{M}^{\oplus}\right)$.

$$
\mathrm{C}_{16} \mathrm{H}_{18} \mathrm{~N}_{2} \mathrm{O}_{4} \text { (302.3) Ber. C } 63.57 \mathrm{H} 6.00 \mathrm{~N} 9.27 \text { Gef. C } 63.59 \mathrm{H} 6.01 \mathrm{~N} 9.10
$$

Durch Einengen der Aceton/Methanollösung i. Vak. (s. oben) und Umkristallisation aus Essig-

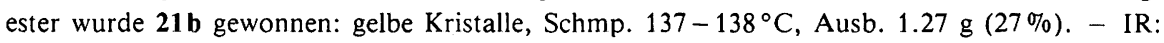


1690, $1500 \mathrm{~cm}^{-1} .-{ }^{1} \mathrm{H}-\mathrm{NMR}\left(\mathrm{CDCl}_{3}\right): \delta=2.06-2.61(\mathrm{~m}, 2 \mathrm{H}), 2.78(\mathrm{t}, J=5.5 \mathrm{~Hz}, 2 \mathrm{H}), 4.43$ (t, $J=5.0 \mathrm{~Hz}, 2 \mathrm{H}), 6.7(\mathrm{~s}, 1 \mathrm{H}), 7.9(\mathrm{~d}, J=9 \mathrm{~Hz}, 2 \mathrm{H}), 8.23(\mathrm{~d}, J=9 \mathrm{~Hz}, 2 \mathrm{H})$.

5, (5-Dihydro-4-(2-nitrobenzyliden)-2H-pyran-3(4H)-on (23a): $3.77 \mathrm{~g}(15 \mathrm{mmol}) 31 \mathrm{a}$ und 0.2 $p$-Tolluolsulfonsäure wurden in $300 \mathrm{ml}$ absol. Benzol $1 \mathrm{~h}$ rückfließend erhitzt. Es wurde i. Vak. eingedampft und der Rückstand aus Essigester umkristallisiert: hellgelbe Kristalle, Schmp. $125-127^{\circ} \mathrm{C}$, Ausb. $1.38 \mathrm{~g} \mathrm{(39 \% )}$ ). IR: $1685,1595,1510 \mathrm{~cm}^{-1}$. $-{ }^{1} \mathrm{H}-\mathrm{NMR}\left(\mathrm{CDCl}_{3}\right): \delta=2.73$ $(\mathrm{td}, J=5.5,2 \mathrm{~Hz}, 2 \mathrm{H}), 3.88(\mathrm{t}, J=5.5 \mathrm{~Hz}, 2 \mathrm{H}), 4.30(\mathrm{~s}, 2 \mathrm{H}), 7.25-7.73(\mathrm{~m}, 3 \mathrm{H}), 7.78-7.97$ $(\mathrm{m}, 1 \mathrm{H}), 8.15(\mathrm{dd}, J=7,2 \mathrm{~Hz}, 1 \mathrm{H})$. $-\mathrm{MS}: m / e=233\left(\mathrm{M}^{\oplus}\right)$.

\section{$\mathrm{C}_{12} \mathrm{H}_{11} \mathrm{NO}_{4}$ (233.2) Ber. C $61.80 \mathrm{H} 4.75$ N 6.01 Gef. C $61.76 \mathrm{H} 4.81 \mathrm{~N} 5.88$}

5, 6-Dihydro-4-(4-nitrobenzyliden)-2H-pyran-3(4H)-on (23b): A) Darstellung wie bei 23a angegebe:n aus $1.51 \mathrm{~g}(6 \mathrm{mmol}) 31 \mathrm{~b}$; Umkristallisation aus Essigester; hellgelbe Kristalle, Schmp. $155-156^{\circ} \mathrm{C}$, Ausb. $0.96 \mathrm{~g}(69 \%)$. - IR: $1690,1600,1590 \mathrm{~cm}^{-1} .-{ }^{1} \mathrm{H}-\mathrm{NMR}\left(\mathrm{CDCl}_{3}\right): \delta=3.02$ (td, $J=5.5,2.5 \mathrm{~Hz}, 2 \mathrm{H}), 3.67(\mathrm{t}, J=5.5 \mathrm{~Hz}, 2 \mathrm{H}), 4.30(\mathrm{~s}, 2 \mathrm{H}), 7.53(\mathrm{~d}, J=9.5 \mathrm{~Hz}, 2 \mathrm{H}), 7.63$ $(1 \mathrm{H}$, Aufspaltung wegen Überlagerung nicht zu erkennen), $8.23(\mathrm{~d}, J=5.5 \mathrm{~Hz}, 2 \mathrm{H})$. - MS: $m / e=233\left(\mathrm{M}^{\oplus}\right)$.

$$
\mathrm{C}_{12} \mathrm{H}_{11} \mathrm{NO}_{4} \text { (233.2) Ber. C } 61.80 \mathrm{H} 4.75 \text { N } 6.01 \text { Gef. C } 61.77 \mathrm{H} 4.74 \text { N } 5.98
$$

B) Eine Lösung von $0.1 \mathrm{~g}(0.33 \mathrm{mmol}) 22$ in $100 \mathrm{ml}$ Diethylether wurde mit $20 \mathrm{ml} 6 \mathrm{~N}$ Salzsäure versetzt und 84 h bei Raumtemp. gerührt. Die organische Phase wurde abgetrennt, getrocknet und eingeengt; schwach gelber Feststoff, Ausb. $0.05 \mathrm{~g}(65 \%)$. Das Produkt wurde mittels DC (Essigester/Dichlormethan, 1:9) und ${ }^{1} \mathrm{H}-\mathrm{NMR}$-spektroskopisch indentifiziert.

5, 6-Dihydro-4-benzyliden-2H-pyran-3(4H)-on (23c): $1.03 \mathrm{~g}(5 \mathrm{mmol}) 31 \mathrm{c}$ wurden bei Raumtemp. in $50 \mathrm{ml} 85 \mathrm{proz}$. Phosphorsäure suspendiert. Nach $3 \mathrm{~h}$ wurde vorsichtig mit Wasser versetzt und anschließend mehrmals mit Dichlormethan extrahiert. Die vereinigten Extrakte wurden mit Wasser gewaschen, getrocknet (Natriumsulfat) und i. Vak. eingeengt. Der Rückstand wurde mittels DC gereinigt (Essigester/Dichlormethan, 1:9). Die Zone mit $R_{\mathrm{F}}=0.74$ wurde entfernt, mit Methanol extrahiert und der Extrakt i. Vak. eingeengt: farblose Kristalle, Schmp. $84.5-86^{\circ} \mathrm{C}$, Ausb. $0.40 \mathrm{~g} \mathrm{(43 \% )}$. - IR: $1675,1590 \mathrm{~cm}^{-1}$. - ${ }^{1} \mathrm{H}-\mathrm{NMR}\left(\mathrm{CDCl}_{3}\right): \delta=3.03(\mathrm{td}$, $J=5.5,2 \mathrm{~Hz}, 2 \mathrm{H}), 3.90(\mathrm{t}, J=5.5 \mathrm{~Hz}, 2 \mathrm{H}), 4.27(\mathrm{~s}, 2 \mathrm{H}), 7.43(\mathrm{~s}, 5 \mathrm{H}), 7.70(\mathrm{t}, J=2 \mathrm{~Hz}, 1 \mathrm{H})$. MS: $m / e=188\left(\mathrm{M}^{\oplus}\right)$.

$$
\mathrm{C}_{12} \mathrm{H}_{12} \mathrm{O}_{2} \text { (188.2) Ber. C } 76.57 \mathrm{H} 6.43 \text { Gef. C } 76.57 \text { H } 6.48
$$

[ $\alpha$-(3,4,5,6-Tetrahydro-3-oxo-2H-pyran-2-yliden)benzyl]benzoat (25a) und (5-Hydroxy-2-oxopentyl)benzoat (29): Eine Mischung von $2.03 \mathrm{~g}(12 \mathrm{mmol}) \mathbf{1 5 d} / 17 \mathrm{~d}, 1.82 \mathrm{~g}(18 \mathrm{mmol})$ Triethylamin und $15 \mathrm{ml}$ absol. Chloroform wurde unter Rückfluß tropfenweise mit $2.42 \mathrm{~g}$ (17.25 mmol) 24 a (in $10 \mathrm{ml}$ absol. Chloroform) versetzt und anschließend $24 \mathrm{~h}$ rückfließend erhitzt. Dann wurde i. Vak. eingedampft, der Rückstand mit Diethylether versetzt und der zurückgebliebene Feststoff abfiltriert. Das Filtrat wurde mit $7.5 \mathrm{ml} 6 \mathrm{~N}$ Salzsäure versetzt, $5 \mathrm{~h}$ gerührt und nach Trocknen (Natriumsulfat) i. Vak. eingeengt. Aus Essigester/Pentan entstand 29 als farblose Kristalle mit Schmp. $83.5^{\circ} \mathrm{C}$; Ausb. $0.1 \mathrm{~g}(4 \%)$. - IR: $3200,1725,1685 \mathrm{~cm}^{-1}$. - ${ }^{1} \mathrm{H}-\mathrm{NMR}\left(\mathrm{CDCl}_{3}\right): \delta=$ $1.8-2.23(\mathrm{~m}, 2 \mathrm{H}), 2.53(\mathrm{t}, J=6.5 \mathrm{~Hz}, 2 \mathrm{H}), 3.65(\mathrm{t}, J=6 \mathrm{~Hz}, 2 \mathrm{H}), 7.25-7.65(\mathrm{~m}, 3 \mathrm{H})$, $7.82-8.06(\mathrm{~m}, 2 \mathrm{H}), 11.23\left(\mathrm{~s}, 1 \mathrm{H}, \mathrm{D}_{2} \mathrm{O}-\right.$ Austausch $) .-{ }^{13} \mathrm{C}-\mathrm{NMR}\left(\mathrm{CDCl}_{3}\right): \delta=24.7(\mathrm{t}), 30.5(\mathrm{t})$, $70.4(\mathrm{t}), 73.7$ (t), 127.9 (d), $128.6(\mathrm{~d}), 133.4(\mathrm{~d}), 178.8(\mathrm{~s}), 196.5(\mathrm{~s}) .-\mathrm{MS}: m / e=222\left(\mathrm{M}^{\oplus}\right)$.

$$
\mathrm{C}_{12} \mathrm{H}_{14} \mathrm{O}_{4}(222.2) \text { Ber. C } 64.85 \mathrm{H} 6.35 \text { Gef. C } 64.70 \mathrm{H} 6.08
$$

Der aus Diethylether isolierte Feststoff (siehe oben) wurde in Chloroform gelöst, die Lösung mit $8 \mathrm{~N}$ Salzsäure versetzt und $8 \mathrm{~h}$ gerührt. Die organische Lösung wurde getrocknet (Natriumsulfat), i. Vak. eingeengt und der Rückstand aus Essigester/Pentan umkristallisiert; hellgelbe Kristalle (25a), Schmp. $61^{\circ} \mathrm{C}$, Ausb. $0.7 \mathrm{~g}(15 \%)$. - IR: 1745, 1685, $1645 \mathrm{~cm}^{-1} .-{ }^{1} \mathrm{H}-\mathrm{NMR}\left(\mathrm{CDCl}_{3}\right)$ : 
$\delta=2.0-2.44(\mathrm{~m}, 2 \mathrm{H}), 2.67(\mathrm{t}, J=6 \mathrm{~Hz}, 2 \mathrm{H}), 4.25(\mathrm{t}, J=5 \mathrm{~Hz}, 2 \mathrm{H}), 7.2-7.62(\mathrm{~m}, 6 \mathrm{H})$, $7.74-8.0(\mathrm{~m}, 4 \mathrm{H})$. - MS: $m / e=308\left(\mathrm{M}^{\oplus}\right)$.

$$
\mathrm{C}_{19} \mathrm{H}_{16} \mathrm{O}_{4} \text { (308.3) Ber. C } 74.01 \mathrm{H} 5.23 \text { Gef. C } 74.01 \mathrm{H} 5.12
$$

[4-Nitro- $\alpha$-(3,4,5, 6-tetrahydro-3-oxo-2H-pyran-2-yliden)benzyl]-4-nitrobenzoat (25b): Herstellung wie bei $25 \mathrm{a}$ angegeben aus $4.23 \mathrm{~g}(25 \mathrm{mmol}) 15 \mathrm{~d} / 17 \mathrm{~d}, 10.21 \mathrm{~g}(55 \mathrm{mmol}) 24 \mathrm{~b}$ und $5.57 \mathrm{~g}(55$ mmol) Triethylamin in der Siedehitze, dann $12 \mathrm{~h}$ Raumtemp. und Hydrolyse mit $12.5 \mathrm{ml} 2.5 \mathrm{~N}$ Salzsäure 24 h (Raumtemp.); Umkristallisation aus Essigester (ohne SC und Destillation); farblose Kristalle, Schmp. $126.5-127.5^{\circ} \mathrm{C}$, Ausb. $5.6 \mathrm{~g} \mathrm{(56 \% )}$. - IR: $1760,1690,1630 \mathrm{~cm}^{-1}$. ${ }^{1} \mathrm{H}-\mathrm{NMR}\left(\mathrm{CDCl}_{3}\right): \delta=1.85-2.30(\mathrm{~m}, 2 \mathrm{H}), 2.68(\mathrm{t}, J=6 \mathrm{~Hz}, 2 \mathrm{H}), 4.0(\mathrm{t}, J=5 \mathrm{~Hz}, 2 \mathrm{H})$, $7.38-8.30(\mathrm{~m}, 8 \mathrm{H})$. - MS: $m / e=248\left(\mathrm{M}^{\oplus}-\mathrm{NO}_{2} \mathrm{C}_{6} \mathrm{H}_{4} \mathrm{CO}\right)$.

$$
\mathrm{C}_{19} \mathrm{H}_{14} \mathrm{~N}_{2} \mathrm{O}_{8} \text { (398.3) Ber. C } 57.29 \mathrm{H} 3.54 \text { N 7.03 Gef. C } 57.25 \mathrm{H} 3.58 \text { N } 6.97
$$

2-Benzoyl-5,6-dihydro-2H-pyran-3(4H)-on (26a): $3.38 \mathrm{~g} \mathrm{(20} \mathrm{mmol)} \mathrm{15d/17} \mathrm{d,} 2.23 \mathrm{~g} \mathrm{(22} \mathrm{mmol)}$ Triethylamin und $20 \mathrm{ml}$ absol. Dichlormethan wurden zum Sieden erhitzt und unter Rühren mit $2.81 \mathrm{~g}$ (20 mmol) 23a (in $10 \mathrm{ml}$ absol. Dichlormethan) versetzt. Es wurde $15 \mathrm{~h}$ rückfließend erhitzt und nach Zusatz von $10 \mathrm{ml} 2.5 \mathrm{~N}$ Salzsäure weitere $5 \mathrm{~h}$. Die Dichlormethanlösung wurde mit Wasser gewaschen, getrocknet (Natriumsulfat) und i. Vak. eingeengt. Der Rückstand wurde durch SC gereinigt (Füllhöhe $10 \mathrm{~cm}$; Dichlormethan). Die ersten, gelben Fraktionen wurden gesammelt, i. Vak. eingedampft und der Rückstand bei $10^{-4}$ Torr destilliert (Badtemp. $85-95^{\circ} \mathrm{C}$ ): gelbes Öl, Ausb. $1.2 \mathrm{~g} \mathrm{(29 \% ).} \mathrm{-} \mathrm{IR:} \mathrm{2940,} \mathrm{1600,} 1285 \mathrm{~cm}^{-1} \cdot{ }^{1} \mathrm{H}-\mathrm{NMR}\left(\mathrm{CDCl}_{3}\right): \delta=$ $1.72-2.2(\mathrm{~m}, 2 \mathrm{H}), 2.53(\mathrm{t}, J=6.5 \mathrm{~Hz}, 2 \mathrm{H}), 3.93(\mathrm{t}, J=5 \mathrm{~Hz}, 2 \mathrm{H}), 7.17-7.57(\mathrm{~m}, 3 \mathrm{H})$, $7.73-8.13(\mathrm{~m}, 2 \mathrm{H}), 14.5\left(\mathrm{~s}, 1 \mathrm{H}, \mathrm{D}_{2} \mathrm{O}-\right.$ Austausch). $-\mathrm{MS}: m / e=204\left(\mathrm{M}^{\oplus}\right)$.

$$
\mathrm{C}_{12} \mathrm{H}_{12} \mathrm{O}_{3} \text { (204.2) Ber. C } 70.58 \mathrm{H} 5.92 \text { Gef. C } 70.47 \mathrm{H} 5.91
$$

5,6-Dihydro-2-(4-nitrobenzoyl)-2H-pyran-3(4H)-on (26b): $2.0 \mathrm{~g}(5 \mathrm{mmol}) 25 \mathrm{~b}$ wurden im Eisbad unter Rühren mit $1.75 \mathrm{~g}(20 \mathrm{mmol})$ 19d versetzt. Nach Abklingen der Reaktion wurde mit $5 \mathrm{ml}$ Chloroform verdünnt und $45 \mathrm{~min}$ bei Raumtemp. gerührt. Dann wurde erneut Chloroform $(15 \mathrm{ml})$ zugesetzt und $3 \mathrm{~h}$ mit $2 \mathrm{~N}$ Salzsäure $(15 \mathrm{ml})$ hydrolysiert. Die organische Lösung wurde mit Wasser ausgeschüttelt, i. Vak. eingeengt und der Rückstand durch SC gereinigt (Füllhöhe $15 \mathrm{~cm}$; Essigester/Dichlormethan, 3:7; 15-ml-Fraktionen). Nach dem Einengen der Fraktionen 4-7 (gelbe Zone) wurde aus Essigester umkristallisiert: gelbgrüne Kristalle, Schmp. $110-112.5^{\circ} \mathrm{C}$,

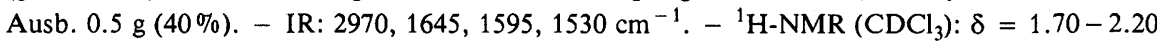
$(\mathrm{m}, 2 \mathrm{H}), 2.58(\mathrm{t}, J=6 \mathrm{~Hz}, 2 \mathrm{H}), 3.82(\mathrm{t}, J=5 \mathrm{~Hz}, 2 \mathrm{H}), 7.45-8.20(\mathrm{~m}, 4 \mathrm{H}), 12.65(\mathrm{~s}, 1 \mathrm{H}$, $\mathrm{D}_{2} \mathrm{O}$-Austausch). - MS: $m / e=249\left(\mathrm{M}^{\oplus}\right)$.

$$
\mathrm{C}_{12} \mathrm{H}_{11} \mathrm{NO}_{5}(249.2) \text { Ber. C } 57.83 \text { H } 4.45 \text { N } 5.62 \text { Gef. C } 57.88 \text { H } 4.51 \text { N } 5.53
$$

2-[(3,4,5,6-Tetrahydro-3-oxo-2H-pyran-2-yl)carbonyl]phenylacetat (26c): Herstellung wie bei 26a angegeben; Raumtemp. (60 h), $5.08 \mathrm{~g}(30 \mathrm{mmol}) 15 \mathrm{~d} / 17 \mathrm{~d}, 6.95 \mathrm{~g}(34.5 \mathrm{mmol}) 24 \mathrm{c}$ und $3.46 \mathrm{~g}$ (30 mmol) Triethylamin, Hydrolyse unter Rückfluß mit $15 \mathrm{ml} 6 \mathrm{~N}$ Salzsäure, keine SC, Destillation bei $10^{-4}$ Torr (Badtemp. $140-170^{\circ} \mathrm{C}$ ). Nach Umkristallisation aus Essigester/Pentan: hell-

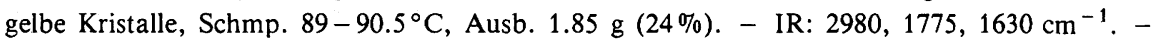
${ }^{1} \mathrm{H}-\mathrm{NMR}\left(\mathrm{CDCl}_{3}\right): \delta=1.70-2.18(\mathrm{~m}, 2 \mathrm{H}), 2.24(\mathrm{~s}, 3 \mathrm{H}), 2.54(\mathrm{t}, 2 \mathrm{H}), 3.86(\mathrm{t}, J=5 \mathrm{~Hz}, 2 \mathrm{H})$, $7.02-7.70(\mathrm{~m}, 4 \mathrm{H}), 13.75\left(\mathrm{~s}, 1 \mathrm{H}, \mathrm{D}_{2} \mathrm{O}\right.$-Austausch). - MS: $m / e=262\left(\mathrm{M}^{\oplus}\right)$.

$$
\mathrm{C}_{14} \mathrm{H}_{14} \mathrm{O}_{5}(262.3) \text { Ber. C } 64.12 \mathrm{H} 5.38 \text { Gef. C } 63.88 \mathrm{H} 5.40
$$

7,8-Dihydro-2,4-diphenyl-6H-pyrano[3,2-d]pyrimidin (28): Eine Lösung von $0.82 \mathrm{~g} \mathrm{(4 \textrm {mmol } )}$ $26 \mathrm{a}$ und $0.58 \mathrm{~g}(4.8 \mathrm{mmol}) 27 \mathrm{in} 20 \mathrm{ml}$ absol. Toluol wurde $8 \mathrm{~h}$ rückfließend erhitzt. Die Reaktionslösung wurde filtriert, das Filtrat i. Vak. eingeengt und der Rückstand erst aus Methanol und dann aus Cyclohexan umkristallisiert: farblose Kristalle, Schmp. $144-147^{\circ} \mathrm{C}$, Ausb. $0.32 \mathrm{~g}(28 \%)$. - IR: $2950,1650,1405 \mathrm{~cm}^{-1}$. - ${ }^{1} \mathrm{H}-\mathrm{NMR}\left(\mathrm{CDCl}_{3}\right): \delta=1.88-2.47(\mathrm{~m}, 2 \mathrm{H}), 3.07$ 
$(\mathrm{t}, J=6.5 \mathrm{~Hz}, 2 \mathrm{H}), 4.33(\mathrm{t}, J=5 \mathrm{~Hz}, 2 \mathrm{H}), 7.30-7.77(\mathrm{~m}, 6 \mathrm{H}), 8.08-8.63(\mathrm{~m}, 4 \mathrm{H}) .-\mathrm{MS}$ : $m / e=288\left(\mathrm{M}^{\oplus}\right)$.

$$
\mathrm{C}_{19} \mathrm{H}_{16} \mathrm{~N}_{2} \mathrm{O}(288.3) \quad \text { Ber. C } 79.14 \text { H } 5.59 \text { N } 9.72 \text { Gef. C } 79.25 \mathrm{H} 5.54 \text { N } 9.63
$$

3,4-Dihydro-2H-pyrano[3,2-d]chinolin-10(5H)-on (30a): In einer Lösung von $1.99 \mathrm{~g} \mathrm{(8} \mathrm{mmol)}$ 26b in $80 \mathrm{ml}$ absol. Diethylether wurden $4.55 \mathrm{~g}$ ( $24 \mathrm{mmol})$ Zinn(II)-chlorid suspendiert. Dann wurde Chlorwasserstoff bis zur Sättigung eingeleitet und anschließend $2 \mathrm{~h}$ bei Raumtemp. gerührt. Nach dem Eindampfen i. Vak. wurde unter heftigem Rühren und Eiskühlung mit $70 \mathrm{ml}$ 40proz. Ammoniumpolysulfid und anschließend mit $50 \mathrm{ml}$ Tetrahydrofuran versetzt. Der an der Phasengrenzfläche aufgetretene Niederschlag wurde isoliert und zusammen mit dem aus der Tetrahydrofuranlösung gewonnenen Material durch SC gereinigt (Füllhöhe $13 \mathrm{~cm}$; Ethanol, 15-ml-Fraktionen). Die Fraktionen 7-9 wurden i. Vak. eingeengt und der Rückstand wurde aus Ethanol/Methanol umkristallisiert: farblose Kristalle, Schmp. $275-280^{\circ} \mathrm{C}$ (Zers.), Ausb. $0.28 \mathrm{~g}$ (17\%). - IR: $1630,1555,1490 \mathrm{~cm}^{-1}$. - ${ }^{1} \mathrm{H}-\mathrm{NMR}$ ([D $\left.\mathrm{D}_{6} \mathrm{DMSO}\right): \delta=1.84-2.3(\mathrm{~m}, 2 \mathrm{H}), 2.9(\mathrm{t}$, $J=6.5 \mathrm{~Hz}, 2 \mathrm{H}), 4.15(\mathrm{t}, J=5.0 \mathrm{~Hz}, 2 \mathrm{H}), 7.1-7.7(\mathrm{~m}, 3 \mathrm{H}), 8.18(\mathrm{~d}, J=8 \mathrm{~Hz}, 1 \mathrm{H}), 11.85$ $\left(1 \mathrm{H}, \mathrm{D}_{2} \mathrm{O}\right.$-Austausch). $\quad{ }^{13} \mathrm{C}-\mathrm{NMR}\left(\left[\mathrm{D}_{6}\right] \mathrm{DMSO}\right): \delta=21.13,23.01,65.05,117.42,121.52$, $123.87,124.93,130.46,132.65,137.78,137.92,169.05$. - MS: $m / e=201\left(\mathrm{M}^{\oplus}\right)$.

$$
\mathrm{C}_{12} \mathrm{H}_{11} \mathrm{NO}_{2} \text { (201.2) Ber. C } 71.63 \text { H } 5.51 \text { N } 5.96 \text { Gef. C } 71.24 \text { H } 5.60 \text { N } 6.96
$$

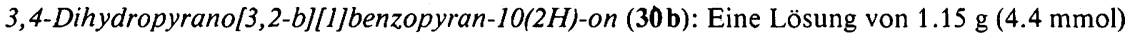
$26 \mathrm{c}$ in $50 \mathrm{ml}$ absol. Methanol wurde mit Chlorwasserstoff gesättigt und $1 \mathrm{~h}$ rückfließend erhitzt. Nach Verdampfen des Lösungsmittels i. Vak. wurde mit Diethylether versetzt und mit Wasser gewaschen. Die Etherphase wurde eingeengt und der Rückstand aus Essigester umkristallisiert: farblose Kristalle, Schmp. $105-107^{\circ} \mathrm{C}$, Ausb. $0.22 \mathrm{~g}(25 \%)$. - IR: 2970, 1645, 1630, $1615 \mathrm{~cm}^{-1}$. - ' $\mathrm{H}-\mathrm{NMR}\left(\mathrm{CDCl}_{3}\right): \delta=1.9-2.4(\mathrm{~m}, 2 \mathrm{H}), 2.84(\mathrm{t}, J=6 \mathrm{~Hz}, 2 \mathrm{H}), 4.22(\mathrm{t}, J=$ $5 \mathrm{~Hz}, 2 \mathrm{H}), 7.17-7.8(\mathrm{~m}, 3 \mathrm{H}), 8.3(\mathrm{dd}, J=8,2 \mathrm{~Hz}, 1 \mathrm{H}) .-{ }^{13} \mathrm{C}-\mathrm{NMR}\left(\mathrm{CDCl}_{3}\right): \delta=20.99(\mathrm{t})$, $23.71(\mathrm{t}), 65.47(\mathrm{t}), 117.19(\mathrm{~d}), 123.81(\mathrm{~s}), 123.56(\mathrm{~d}), 125.87(\mathrm{~d}), 132.36(\mathrm{~d}), 138.76(\mathrm{~s}), 149.08(\mathrm{~s})$, $154.44(\mathrm{~s}), 171.18(\mathrm{~s})$. - MS: $m / e=202\left(\mathrm{M}^{\oplus}\right)$.

$$
\mathrm{C}_{12} \mathrm{H}_{10} \mathrm{O}_{3} \text { (202.2) Ber. C } 71.28 \mathrm{H} 4.98 \text { Gef. C } 71.12 \mathrm{H} 5.15
$$

3,4-Dihydro[IJbenzothiopyrano[3,2-d]pyran-10(2H)-on (30c): Eine Mischung von $3.38 \mathrm{~g}$ (20 $\mathrm{mmol}) 15 \mathrm{~d} / 17 \mathrm{~d}, 2.22 \mathrm{~g}$ (22 mmol) Triethylamin und $20 \mathrm{ml}$ absol. Dichlormethan wurde in der Siedehitze tropfenweise mit einer Lösung von $3.43 \mathrm{~g}(10 \mathrm{mmol}) \mathbf{2 4 d}$ in $40 \mathrm{ml}$ absol. Dichlormethan versetzt. Dann wurde $36 \mathrm{~h}$ unter Rückfluß, $120 \mathrm{~h}$ bei Raumtemp. und nach Zusatz von $20 \mathrm{ml} 1 \mathrm{~N}$ Salzsäure weitere $72 \mathrm{~h}$ bei Raumtemp. gerührt. Die organische Lösung wurde mit $0.2 \mathrm{~N}$ Natronlauge geschüttelt, getrocknet (Natriumsulfat) und i. Vak. eingeengt. Der Rückstand wurde durch SC gereinigt (Füllhöhe $16 \mathrm{~cm}$; Essigester/Dichlormethan, 3:7; 25-ml-Fraktionen). Die Fraktionen 5-7 wurden i. Vak. eingeengt und der Rückstand aus Essigester umkristallisiert: hellgelbe Kristalle, Schmp. $172-175^{\circ} \mathrm{C}$ (Zers.), Ausb. 0.1 g (5\%). - IR: 1615, 1585, $1190 \mathrm{~cm}^{-1}$. - ${ }^{1} \mathrm{H}-\mathrm{NMR}\left(\mathrm{CDCl}_{3}\right): \delta=1.9-2.4(\mathrm{~m}, 2 \mathrm{H}), 2.78(\mathrm{t}, J=6 \mathrm{~Hz}, 2 \mathrm{H}), 4.37(\mathrm{t}, J=$ $5 \mathrm{~Hz}, 2 \mathrm{H}), 7.2-7.7(\mathrm{~m}, 3 \mathrm{H}), 8.4-8.75(\mathrm{~m}, 1 \mathrm{H}) .-{ }^{13} \mathrm{C}-\mathrm{NMR}\left(\mathrm{CDCl}_{3}\right): \delta=21.63(\mathrm{t}), 25.72(\mathrm{t})$, $66.46(\mathrm{t}), 123.74$ (s), 125.22 (d), 126.22 (d), 129.19 (d), 130.67 (d), 131.61 (s), $136.16(\mathrm{~s}), 144.70$ (s), $174.10(\mathrm{~s})$. - MS: $m / e=218\left(\mathrm{M}^{\oplus}\right)$.

$$
\mathrm{C}_{12} \mathrm{H}_{10} \mathrm{O}_{2} \mathrm{~S}(218.3) \text { Ber. C } 66.03 \mathrm{H} 4.62 \mathrm{~S} 14.69 \text { Gef. C65.98 H 4.64 S } 14.64
$$

5,6-Dihydro-4-( $\alpha$-hydroxy-2-nitrobenzyl)-2H-pyran-3(4H)-on (31 a): $6.04 \mathrm{~g}(44 \mathrm{mmol}) 20 \mathrm{a}$, $8.34 \mathrm{~g}(44 \mathrm{mmol})$ Titan(IV)-chlorid in $150 \mathrm{ml}$ absol. Dichlormethan wurden bei $-78^{\circ} \mathrm{C}$ unter Rühren tropfenweise mit einer Mischung aus $6.0(40 \mathrm{mmol}) 18$ und $60 \mathrm{ml}$ absol. Dichlormethan versetzt. Dann wurde $1 \mathrm{~h}$ bei $-78^{\circ} \mathrm{C}$ und eine weitere Stunde bei $0^{\circ} \mathrm{C}$ gerührt. Nach Hydrolyse mit $200 \mathrm{ml}$ eisgekühltem Wasser wurde die organische Phase abgetrennt, getrocknet (Natriumsulfat) und i. Vak. eingeengt. Der Rückstand wurde aus Methanol [Ausb. $9.18 \mathrm{~g}(91 \%)$ ] und für

Liebigs Ann. Chem. 1984 
analytische Zwecke zusätzlich aus Benzol umkristallisiert: farblose Kristalle, Schmp. 108 bis $112^{\circ} \mathrm{C}$. - IR: $1715,1530 \mathrm{~cm}^{-1} .-{ }^{1} \mathrm{H}-\mathrm{NMR}\left(\mathrm{CDCl}_{3}\right): \delta=1.58-2.28(\mathrm{~m}, 2 \mathrm{H}), 2.77-3.32(\mathrm{~m}$, $2 \mathrm{H}), 3.5$ (s, $\mathrm{D}_{2} \mathrm{O}$-Austausch), $3.70-4.18(\mathrm{~m}, 2 \mathrm{H}), 4.05(\mathrm{~s}, 2 \mathrm{H}), 5.55(\mathrm{~d}, J=7 \mathrm{~Hz}, 1 \mathrm{H})$, $7.22-7.98(\mathrm{~m}, 4 \mathrm{H})$. - MS: $m / e=251\left(\mathrm{M}^{\oplus}\right)$.

$$
\mathrm{C}_{12} \mathrm{H}_{13} \mathrm{NO}_{5} \text { (251.2) Ber. C } 57.37 \text { H } 5.22 \text { N } 5.58 \text { Gef. C } 56.72 \text { H } 5.64 \text { N } 5.13
$$

5,6-Dihydro-4-( $\alpha$-hydroxy-4-nitrobenzyl)-2H-pyran-3(4H)-on (31 b): Darstellung wie bei 31 a beschrieben durch Umsetzung von $3.45 \mathrm{~g}(20 \mathrm{mmol}) 18,3.02 \mathrm{~g}(22 \mathrm{mmol}) 20 \mathrm{~b}$ und $4.17 \mathrm{~g}(22$ mmol) Titan(IV)-chlorid; Umkristallisation aus Methanol: farblose Kristalle, Schmp. $146.5^{\circ} \mathrm{C}$, Ausb. $2.61 \mathrm{~g}(52 \%)$. - IR: $3430,1715,1510 \mathrm{~cm}^{-1}$. - ${ }^{1} \mathrm{H}-\mathrm{NMR}$ ([D $]$ DMSO): $\delta=1.32-2.2$ (m, $2 \mathrm{H}), 2.82-3.23(\mathrm{~m}, 1 \mathrm{H}), 3.57-4.03(\mathrm{~m}, 2 \mathrm{H}), 3.88(\mathrm{~s}, 2 \mathrm{H}), 5.2(\mathrm{t}, J=4.5 \mathrm{~Hz}, 1 \mathrm{H}), 5.7(\mathrm{~d}, J=$ $4.5 \mathrm{~Hz}, 1 \mathrm{H}, \mathrm{D}_{2} \mathrm{O}$-Austausch), $7.55(\mathrm{~d}, J=9 \mathrm{~Hz}, 2 \mathrm{H}), 8.12(\mathrm{~d}, J=9 \mathrm{~Hz}, 2 \mathrm{H})$. $-\mathrm{MS}: m / e=$ $233\left(\mathrm{M}^{\oplus}-\mathrm{H}_{2} \mathrm{O}\right)$.

$$
\mathrm{C}_{12} \mathrm{H}_{13} \mathrm{NO}_{5} \text { (251.2) Ber. C } 57.37 \text { H } 5.22 \text { N } 5.58 \text { Gef. C } 57.27 \text { H } 5.11 \text { N } 5.51
$$

5,6-Dihydro-4-( $\alpha$-hydroxybenzyl)-2H-pyran-3(4H)-on (31c): Darstellung wie bei 31 a beschrieben durch Umsetzung von $6.9 \mathrm{~g} \mathrm{(40} \mathrm{mmol)} 18,4.66 \mathrm{~g}(44 \mathrm{mmol}) 20 \mathrm{c}$ und $8.34 \mathrm{~g}$ (44 mmol) Titan(IV)-chlorid; Umkristallisation aus Methanol. Den spektroskopischen Daten zufolge liegt die Verbindung als Methanolhalbacetal vor; farblose Kristalle, Schmp. $96-98^{\circ} \mathrm{C}$, Ausb. $3.81 \mathrm{~g}$ $(40 \%)$. - IR: $3410,3330,1450 \mathrm{~cm}^{-1}$. $-{ }^{1} \mathrm{H}-\mathrm{NMR}\left(\mathrm{CDCl}_{3}\right): \delta=1.10-2.30(\mathrm{~m}, 3 \mathrm{H})$, $2.93-3.35\left(\mathrm{~m}, 3 \mathrm{H}, 1 \mathrm{H}, \mathrm{D}_{2} \mathrm{O}\right.$-Austausch), $3.0(\mathrm{~d}, J=13 \mathrm{~Hz}, 1 \mathrm{H}), 3.38(\mathrm{~s}, 3 \mathrm{H}), 3.62-4.07(\mathrm{~m}$, $2 \mathrm{H}), 4.00(\mathrm{~d}, J=13 \mathrm{~Hz}, 1 \mathrm{H}), 5.02(\mathrm{~d}, J=9 \mathrm{~Hz}, 1 \mathrm{H}), 5.83$ (s, $1 \mathrm{H}, \mathrm{D}_{2} \mathrm{O}$-Austausch), 7.38 (s, 5H). - MS: $m / e=220\left(\mathrm{M}^{\oplus}-\mathrm{H}_{2} \mathrm{O}\right)$.

$$
\mathrm{C}_{12} \mathrm{H}_{14} \mathrm{O}_{3} \cdot \mathrm{CH}_{3} \mathrm{OH}(238.3) \text { Ber. C } 65.53 \mathrm{H} 7.61 \text { Gef. C } 65.87 \mathrm{H} 7.48
$$

5,6-Dihydro-4-(3,4,5,6-tetrahydro-3-hydroxy-2H-pyran-3-yl)-2H-pyran-3(4H)-on (32): $2.2 \mathrm{~g}$ (22 mmol) 3 und $4.17 \mathrm{~g}$ (22 mmol) Titan(IV)-chlorid in $100 \mathrm{ml}$ absol. Dichlormethan wurden bei $0^{\circ} \mathrm{C}$ tropfenweise mit einer Mischung von $3.45 \mathrm{~g}(20 \mathrm{mmol}) 18$ und $50 \mathrm{ml}$ absol. Dichlormethan versetzt. Nach 2 stdg. Rühren bei $0^{\circ} \mathrm{C}$ wurde mit $150 \mathrm{ml}$ Eis/Wasser versetzt und mit $\mathrm{NaHCO}_{3}$ neutralisiert. Die wäßrige Phase wurde mit Dichlormethan extrahiert, und die vereinigten organischen Extrakte wurden nach Trocknen (Natriumsulfat) i. Vak. eingeengt. Anschließend wurde aus Dichlormethan/Essigester kristallisiert: farblose Kristalle, Schmp. $68-72^{\circ} \mathrm{C}$, Ausb. $0.2 \mathrm{~g}$ $(5 \%)$. - IR: $3390,1715 \mathrm{~cm}^{-1}$. - ${ }^{1} \mathrm{H}-\mathrm{NMR}\left(\mathrm{CDCl}_{3}\right): \delta=1.20-2.37(\mathrm{~m}, 6 \mathrm{H}), 2.87(\mathrm{dd}, J=11$, $7 \mathrm{~Hz}, 1 \mathrm{H}), 3.20-4.07\left(\mathrm{~m}, 7 \mathrm{H}, 1 \mathrm{H}, \mathrm{D}_{2} \mathrm{O}\right.$-Austausch), $3.97(\mathrm{~s}, 2 \mathrm{H}) .-\mathrm{MS}: m / e=200\left(\mathrm{M}^{\oplus}\right)$.

$$
\mathrm{C}_{10} \mathrm{H}_{16} \mathrm{O}_{4}(200.2) \quad \text { Ber. C } 59.98 \mathrm{H} 8.05 \text { Gef. C } 59.77 \mathrm{H} 7.79
$$

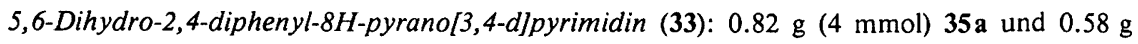
$(4.8 \mathrm{mmol}) 27$ wurden in $20 \mathrm{ml}$ absol. Toluol $2 \mathrm{~h}$ rückfließend erhitzt. Nach dem Abkühlen wurde filtriert, das Filtrat mehrfach mit Wasser ausgeschüttelt, getrocknet (Natriumsulfat) und i. Vak. eingeengt. Der Rückstand wurde aus Methanol umkristallisiert: farblose Kristalle, Schmp. $119-120^{\circ} \mathrm{C}$, Ausb. $0.72 \mathrm{~g}(62 \%)$. - IR: 2960, 1545, $1400 \mathrm{~cm}^{-1}$. - ${ }^{1} \mathrm{H}-\mathrm{NMR}\left(\mathrm{CDCl}_{3}\right): \delta=2.86$ $(\mathrm{t}, J=5.5 \mathrm{~Hz}, 2 \mathrm{H}), 3.88(\mathrm{t}, J=5.5 \mathrm{~Hz}, 2 \mathrm{H}), 4.84(\mathrm{~s}, 2 \mathrm{H}), 7.27-7.90(\mathrm{~m}, 8 \mathrm{H}), 8.30-8.70(\mathrm{~m}$, $2 \mathrm{H})$. - MS: $m / e=288\left(\mathrm{M}^{\oplus}\right)$.

$$
\mathrm{C}_{19} \mathrm{H}_{16} \mathrm{~N}_{2} \mathrm{O}(288.3) \text { Ber. C } 79.14 \text { H } 5.59 \text { N } 9.72 \text { Gef. C } 78.86 \text { H } 5.60 \text { N } 9.91
$$

4-[5,6-Dihydro-2-phenyl-8H-pyrano[3,4-d]pyrimidin-4-yl)methoxy]-1-phenyl-1-butanon (34): $0.11 \mathrm{~g}(0.36 \mathrm{mmol}) 36 \mathrm{a}$ und $0.065 \mathrm{~g}(0.54 \mathrm{mmol}) 27$ wurden in $5 \mathrm{ml}$ absol. Toluol $4 \mathrm{~h}$ rückfließend erhitzt. Die Reaktionsmischung wurde mit Diethylether verdünnt, mit Wasser geschüttelt und nach dem Trocknen (Natriumsulfat) i. Vak. eingeengt. Der Rückstand wurde mittels DC gereinigt (Essigester/Dichlormethan, 1:9). Die Zone mit $R_{\mathrm{F}}=0.44$ wurde entfernt und mit Chloroform extrahiert. Dann wurde i. Vak. eingedampft und der ölige Rückstand mit wenig Cyclohexan ver- 
setzt. Nach mehreren Wochen (bei Raumtemp.) schieden sich farblose Kristalle ab; Schmp. $70-72{ }^{\circ} \mathrm{C}$, Ausb. $0.04 \mathrm{~g}(29 \%)$. - IR: $1680,1555,1400 \mathrm{~cm}^{-1} \cdot-{ }^{1} \mathrm{H}-\mathrm{NMR}\left(\mathrm{CDCl}_{3}\right): \delta=$ $1.80-2.30(\mathrm{~m}, 2 \mathrm{H}), 2.88(\mathrm{t}, J=5.5 \mathrm{~Hz}, 2 \mathrm{H}), 3.10(\mathrm{t}, J=7 \mathrm{~Hz}, 2 \mathrm{H}), 3.65(\mathrm{t}, J=6 \mathrm{~Hz}, 2 \mathrm{H})$, $3.93(\mathrm{t}, J=5.5 \mathrm{~Hz}, 2 \mathrm{H}), 4.60(\mathrm{~s}, 2 \mathrm{H}), 4.77(\mathrm{~s}, 2 \mathrm{H}), 7.10-7.60(\mathrm{~m}, 6 \mathrm{H}), 7.75-8.02(\mathrm{~m}, 2 \mathrm{H})$, $8.22-8.47(\mathrm{~m}, 2 \mathrm{H})$. - MS: $m / e=388\left(\mathrm{M}^{\oplus}\right)$.

$$
\mathrm{C}_{24} \mathrm{H}_{24} \mathrm{~N}_{2} \mathrm{O}_{3} \text { (388.5) Ber. C 74.21 H6.23 N7.21 Gef. C 73.82 H } 6.17 \text { N } 7.04
$$

4-Benzoyl-5,6-dihydro-2H-pyran-3(4H)-on (35a) und 4-[2-(3-Benzoylpropyloxy)-1-hydroxyethylidenJ-5,6-dihydro-2H-pyran-3(4H)-on (36a): 1) $\mathrm{Zu} 10 \mathrm{mmol}$ der bei 14 beschriebenen Enolatlösung ließ man unter Rühren $0.70 \mathrm{~g}(5 \mathrm{mmol}) 24 \mathrm{a}$ in $1 \mathrm{ml}$ absol. Tetrahydrofuran tropfen und hielt noch $0.5 \mathrm{~h}$ bei dieser Temp. Nach Erwärmen auf $-10^{\circ} \mathrm{C}$ wurde in eine eisgekühlte Mischung aus $100 \mathrm{ml}$ Pentan und $10 \mathrm{ml}$ kochsalzgesättigter $2 \mathrm{~N}$ Salzsäure gegossen. Die organische Phase wurde abgetrennt, mit $\mathrm{NaHCO}_{3}$-Lösung und Wasser geschüttelt und getrocknet (Natriumsulfat).

2) Aus der Pentanlösung schied sich bei Raumtemp. 36a als farblose Kristalle ab; Schmp. 96-96.5 ${ }^{\circ} \mathrm{C}$, Ausb. $0.07 \mathrm{~g} \mathrm{(5 \% ),} \mathrm{nicht} \mathrm{umkristallisiert.} \mathrm{-} \mathrm{IR:} \mathrm{1680,} \mathrm{1635,} 1590 \mathrm{~cm}^{-1}$. - ${ }^{1} \mathrm{H}-\mathrm{NMR}$ $\left(\mathrm{CDCl}_{3}\right): \delta=1.9-2.35(\mathrm{~m}, 2 \mathrm{H}), 2.41(\mathrm{t}, J=5.5 \mathrm{~Hz}, 2 \mathrm{H}), 3.15(\mathrm{t}, J=7 \mathrm{~Hz}, 2 \mathrm{H}), 3.64(\mathrm{t}, J=$ $6 \mathrm{~Hz}, 2 \mathrm{H}), 3.8(\mathrm{t}, J=5.5 \mathrm{~Hz}, 2 \mathrm{H}), 4.15(\mathrm{~s}, 2 \mathrm{H}), 4.23(\mathrm{~s}, 2 \mathrm{H}), 7.29-7.71(\mathrm{~m}, 3 \mathrm{H}), 7.88-8.10$ (m, $2 \mathrm{H}), 14.9$ (s, $1 \mathrm{H}, \mathrm{D}_{2} \mathrm{O}$-Austausch). - MS: $m / e=304\left(\mathrm{M}^{\oplus}\right)$.

$$
\mathrm{C}_{17} \mathrm{H}_{20} \mathrm{O}_{5} \text { (304.3) Ber. C } 67.10 \mathrm{H} 6.62 \text { Gef. C } 66.70 \mathrm{H} 6.58
$$

35a wurde gewonnen, indem man die Mutterlauge (Pentanlösung) i. Vak. eindampfte und den Rückstand bei $10^{-3.5}$ Torr und $100-110^{\circ} \mathrm{C}$ Badtemp. destillierte: farblose Kristalle, Schmp. $58-60.5^{\circ} \mathrm{C}$, Ausb. $0.60 \mathrm{~g}\left(59 \%\right.$, nicht umkristallisiert). - IR: $1615,1595,1575 \mathrm{~cm}^{-1}$. ${ }^{1} \mathrm{H}-\mathrm{NMR}\left(\mathrm{CDCl}_{3}\right): \delta=2.58(\mathrm{t}, J=5.5 \mathrm{~Hz}, 2 \mathrm{H}), 3.73(\mathrm{t}, J=5.5 \mathrm{~Hz}, 2 \mathrm{H}), 4.23(\mathrm{~s}, 2 \mathrm{H})$, $7.27-7.72(\mathrm{~m}, 5 \mathrm{H}), 16.4\left(\mathrm{~s}, 1 \mathrm{H}, \mathrm{D}_{2} \mathrm{O}\right.$-Austausch). - MS: $m / e=204\left(\mathrm{M}^{\oplus}\right)$.

$$
\mathrm{C}_{12} \mathrm{H}_{12} \mathrm{O}_{3} \text { (204.2) Ber. C } 70.58 \mathrm{H} 5.92 \text { Gef. C } 70.35 \mathrm{H} 6.00
$$

5,6-Dihydro-4-(2-nitrobenzoyl)-2H-pyran-3(4H)-on (35b): Herstellung nach der unter 36a [1)] angegebenen Methode aus $15 \mathrm{mmol} 14$ und $1.39 \mathrm{~g}$ (7.5 mmol) $24 \mathrm{~b}$. Die organische Phase wurde eingeengt und der Rückstand aus Methanol umkristallisiert: farblose Kristalle, Schmp. $121-123^{\circ} \mathrm{C}$, Ausb. $1.3 \mathrm{~g}(70 \%)$. - IR: $2970,1620,1520 \mathrm{~cm}^{-1}$. $-{ }^{1} \mathrm{H}-\mathrm{NMR}\left(\mathrm{CDCl}_{3}\right): \delta=2.10$ $(\mathrm{t}, J=5.5 \mathrm{~Hz}, 2 \mathrm{H}), 3.72(\mathrm{t}, J=5.5 \mathrm{~Hz}, 2 \mathrm{H}), 4.23(\mathrm{~s}, 2 \mathrm{H}), 7.17-7.77(\mathrm{~m}, 3 \mathrm{H}), 8.12(\mathrm{dd}, J=7$, $2 \mathrm{~Hz}, 1 \mathrm{H}), 14.57\left(1 \mathrm{H}, \mathrm{D}_{2} \mathrm{O}\right.$-Austausch). - MS: $m / e=249\left(\mathrm{M}^{\oplus}\right)$.

$$
\mathrm{C}_{12} \mathrm{H}_{11} \mathrm{NO}_{5}(249.2) \text { Ber. C } 57.83 \mathrm{H} 4.45 \text { N } 5.62 \text { Gef. C } 57.82 \mathrm{H} 4.44 \text { N } 5.78
$$

2-[(3,4,5,6-Tetrahydro-3-oxo-2H-pyran-4-yl)carbonyl]phenylacetat (35c): Herstellung nach der unter 35a [1)] angegebenen Methode aus $15 \mathrm{mmol} 14$ und $1.49 \mathrm{~g} \mathrm{(7.5} \mathrm{mmol)} \mathrm{24c.} \mathrm{Die} \mathrm{organi-}$ sche Phase wurde eingeengt und das Produkt bei $10^{-3}$ Torr und $125-135^{\circ} \mathrm{C}$ Badtemp. destilliert. Das Destillat (Ausb. $1.3 \mathrm{~g}, 66 \%$ ) wurde aus Methanol umkristallisiert: farblose Kristalle, Schmp. $55-56^{\circ} \mathrm{C}$, Ausb. $0.7 \mathrm{~g}(36 \%)$. - IR: $1760,1605 \mathrm{~cm}^{-1}$. $-{ }^{1} \mathrm{H}-\mathrm{NMR}\left(\mathrm{CDCl}_{3}\right): \delta=2.27(\mathrm{~s}, 3 \mathrm{H})$, $2.37(\mathrm{t}, J=5.5 \mathrm{~Hz}, 2 \mathrm{H}), 3.75(\mathrm{t}, J=5.5 \mathrm{~Hz}, 2 \mathrm{H}), 4.25(\mathrm{~s}, 2 \mathrm{H}), 7.03-7.57(\mathrm{~m}, 4 \mathrm{H}), 15.60(\mathrm{~s}$, $1 \mathrm{H}, \mathrm{D}_{2} \mathrm{O}$-Austausch). - MS: $m / e=262\left(\mathrm{M}^{\oplus}\right)$.

$$
\mathrm{C}_{14} \mathrm{H}_{14} \mathrm{O}_{5} \text { (262.3) Ber. C } 64.12 \mathrm{H} 5.38 \text { Gef. C } 64.13 \text { H } 5.30
$$

$S-\langle 2-[(3,4,5,6-T e t r a h y d r o-3-o x o-2 H-p y r a n-4-y l)$ carbonyl]phenyl $\rangle$ thioacetat (35d) und 3,4,4a, 10aTetrahydro-10a-hydroxy-[1]benzothiopyrano[2,3-c]pyran-5(1H)-on (37): Herstellung nach der unter 35a [1)] angegebenen Methode aus $25 \mathrm{mmol} 14$ und $2.68 \mathrm{~g}(12.5 \mathrm{mmol}) 24 \mathrm{e}$ (Hydrolyse nach $1.5 \mathrm{~h}$ bei $\left.-78^{\circ} \mathrm{C}\right)$. Die organische Lösung wurde eingeengt und der Rückstand mittels SC getrennt (Füllhöhe $14 \mathrm{~cm}$; Essigester/Dichlormethan, 1:9; 20-ml-Fraktionen). Nach Eindampfen i. Vak. ergaben die Fraktionen 5-7 ein Produktgemisch (1.43 g) aus 35d und 37, das direkt zur 
Darstellung von 38b eingesetzt wurde. Die Fraktionen $12-21$ wurden i. Vak. eingeengt und lieferten 37 als farblose Kristalle mit Schmp. $137.5^{\circ} \mathrm{C}$; Ausb. $0.3 \mathrm{~g}(10 \%$, nicht umkristallisiert $)$. IR: $3360,1675,1585 \mathrm{~cm}^{-1} .-{ }^{1} \mathrm{H}-\mathrm{NMR}\left(\mathrm{CDCl}_{3}\right): \delta=1.58-2.27(\mathrm{~m}, 2 \mathrm{H}), 2.98-3.72(\mathrm{~m}, 3 \mathrm{H}$, $1 \mathrm{H}, \mathrm{D}_{2} \mathrm{O}$-Austausch), $3.85(\mathrm{~s}, 2 \mathrm{H}), 3.98-4.40(\mathrm{~m}, 1 \mathrm{H}), 7.02-7.57(\mathrm{~m}, 3 \mathrm{H}), 7.97-8.22(\mathrm{~m}$, $1 \mathrm{H})$. - MS: $m / e=236\left(\mathrm{M}^{\oplus}\right)$.

$$
\mathrm{C}_{12} \mathrm{H}_{12} \mathrm{SO}_{3} \text { (236.3) Ber. C } 61.00 \mathrm{H} 5.12 \mathrm{~S} 13.57 \text { Gef. C } 61.33 \mathrm{H} 5.14 \mathrm{~S} 13.45
$$

2-[(3,4,5,6-Tetrahydro-3-oxo-2H-pyran-4-yl)carbonyl]benzylbenzoat (35e) und 2-〈4-[2-Hydroxy2-(3,4,5,6-tetrahydro-3-oxo-2H-pyran-4-yliden)ethoxy]-1-oxobutyl $>$ benzylbenzoat (36 b): Herstellung nach der unter 35a [1)] angegebenen Methode aus $25 \mathrm{mmol} 14$ und $3.43 \mathrm{~g}(12.5 \mathrm{mmol}) 24 \mathrm{f}$. Die organische Lösung wurde eingeengt und der Rückstand aus Diethylether/Methanol $(1: 1)$ fraktionierend kristallisiert. Die erste Kristallfraktion enthielt 36b, das aus Methanol umkristallisiert wurde: blaßbraune Kristalle mit Schmp. $79-81^{\circ} \mathrm{C}$, Ausb. $0.5 \mathrm{~g}(9 \%)$. - IR: 1720, 1675, $1645 \mathrm{~cm}^{-1}$. - ${ }^{1} \mathrm{H}-\mathrm{NMR}\left(\mathrm{CDCl}_{3}\right): \delta=1.87-2.33(\mathrm{~m}, 2 \mathrm{H}), 2.37(\mathrm{t}, 2 \mathrm{H}), 3.10(\mathrm{t}, J=7 \mathrm{~Hz}, 2 \mathrm{H})$, $3.58(\mathrm{t}, 2 \mathrm{H}), 3.75(\mathrm{t}, 2 \mathrm{H}), 4.10(\mathrm{~s}, 2 \mathrm{H}), 4.15(\mathrm{~s}, 2 \mathrm{H}), 7.17-8.20(\mathrm{~m}, 9 \mathrm{H}), 14.87\left(\mathrm{~s}, 1 \mathrm{H}, \mathrm{D}_{2} \mathrm{O}-\right.$ Austausch). - MS: $m / e=438\left(\mathrm{M}^{\oplus}\right)$.

$$
\mathrm{C}_{25} \mathrm{H}_{26} \mathrm{O}_{7} \text { (438.5) Ber. C } 68.48 \mathrm{H} 5.98 \text { Gef. C } 68.04 \mathrm{H} 5.95
$$

Die folgenden Kristallfraktionen enthielten 35e, das aus Methanol umkristallisiert wurde: blaßgelbe Kristalle, Schmp. $66-70^{\circ} \mathrm{C}$, Ausb. $1.38 \mathrm{~g} \mathrm{(33 \% ).} \mathrm{-} \mathrm{IR:} 1715,1595 \mathrm{~cm}^{-1}$. - ${ }^{1} \mathrm{H}-\mathrm{NMR}$ $\left(\mathrm{CDCl}_{3}\right): \delta=2.23(\mathrm{t}, J=5.5 \mathrm{~Hz}, 2 \mathrm{H}), 3.52(\mathrm{t}, J=5.5 \mathrm{~Hz}, 2 \mathrm{H}), 4.12(\mathrm{~s}, 2 \mathrm{H}), 5.42(\mathrm{~s}, 2 \mathrm{H})$, $7.10-7.57(\mathrm{~m}, 7 \mathrm{H}), 7.73-8.03(\mathrm{~m}, 2 \mathrm{H})$. $-\mathrm{MS}: m / e=338\left(\mathrm{M}^{\oplus}\right)$.

$$
\mathrm{C}_{20} \mathrm{H}_{18} \mathrm{O}_{5} \text { (338.4) Ber. C } 71.00 \mathrm{H} 5.36 \text { Gef. C } 70.61 \mathrm{H} 5.42
$$

4-〈1-Hydroxy-2-\{3-[2-(phenylamino)benzoyl]propyloxy\}ethyliden $\rangle-5,6-d i h y d r o-2 H$-pyran3(4H)-on (36c) und 3,4-Dihydro-10-phenyl-1H-pyrano[3,4-b]chinolin-5(10H)-on (38d): Nach der unter 35a [1)] angegebenen Methode wurden $15 \mathrm{mmol} 14 \mathrm{mit} 1.74 \mathrm{~g}$ (7.5 mmol) $24 \mathrm{~g}$ umgesetzt. Ein bei der Hydrolyse (Hydrolysegemisch $+100 \mathrm{ml}$ Diethylether) aufgetretener Niederschlag wurde isoliert. Die organische Phase wurde nach Ausschütteln mit Wasser und nach Trocknen mit Natriumsulfat i. Vak. eingeengt. Der Rückstand kristallisierte aus Essigester. Das so gewonnene Produkt und der aus dem Hydrolysegemisch isolierte Feststoff wurden zusammen aus Methanol umkristallisiert: gelbgrüne Kristalle von 38d mit Schmp. $254-257^{\circ} \mathrm{C}$, Ausb. $0.45 \mathrm{~g}$ (22\%). - IR: $2970,1618,1590 \mathrm{~cm}^{-1}$. - ${ }^{1} \mathrm{H}-\mathrm{NMR}\left(\mathrm{CDCl}_{3}\right): \delta=2.82(\mathrm{t}, J=5 \mathrm{~Hz}, 2 \mathrm{H}$, Homoallylkopplung andeutungsweise zu erkennen), $3.93(\mathrm{t}, J=5.5 \mathrm{~Hz}, 2 \mathrm{H}), 4.15(\mathrm{~s}, 2 \mathrm{H}$, Homoallylkopplung andeutungsweise zu erkennen), $6.55-6.83(\mathrm{~m}, 1 \mathrm{H}), 7.15-7.78(\mathrm{~m}, 7 \mathrm{H}), 8.38-8.63$ (m, $1 \mathrm{H})$. - MS: $m / e=277\left(\mathrm{M}^{\oplus}\right)$.

$$
\mathrm{C}_{18} \mathrm{H}_{15} \mathrm{NO}_{2} \text { (277.3) Ber. C } 77.96 \text { H } 5.45 \text { N } 5.05 \text { Gef. C } 78.03 \text { H } 5.47 \text { N } 4.85
$$

Die Essigester-Mutterlauge (siehe oben) wurde i. Vak. eingeengt und der Rückstand mittels SC gereinigt (Füllhöhe $14 \mathrm{~cm}$; Essigester/Dichlormethan, 3:7; 15-ml-Fraktionen). Nach Einengen der Fraktionen 5- 7 (i. Vak.) und Umkristallisation aus Cyclohexan ließ sich 36c isolieren: gelbe Kristalle mit Schmp. $73-76^{\circ} \mathrm{C}$, Ausb. $0.35 \mathrm{~g}(12 \%)$. - IR: 2920, 1665, $1610 \mathrm{~cm}^{-1}$. - ${ }^{1} \mathrm{H}-\mathrm{NMR}$ $\left(\mathrm{CDCl}_{3}\right): \delta=1.8-2.25(\mathrm{~m}, 2 \mathrm{H}), 2.38(\mathrm{t}, J=5.5 \mathrm{~Hz}, 2 \mathrm{H}), 3.15(\mathrm{t}, J=7 \mathrm{~Hz}, 2 \mathrm{H}), 3.63(\mathrm{t}, J=$ $6 \mathrm{~Hz}, 2 \mathrm{H}), 3.77(\mathrm{t}, J=5.5 \mathrm{~Hz}, 2 \mathrm{H}), 4.13(\mathrm{~s}, 2 \mathrm{H}), 4.20(\mathrm{~s}, 2 \mathrm{H}), 6.50-7.33(\mathrm{~m}, 8 \mathrm{H}), 7.83(\mathrm{~d}, J=$ $8 \mathrm{~Hz}, 1 \mathrm{H}$ ), 10.50 (breit, $1 \mathrm{H}, \mathrm{D}_{2} \mathrm{O}$-Austausch), 14.92 (s, $1 \mathrm{H}, \mathrm{D}_{2} \mathrm{O}$-Austausch). - MS: $m / e=395$ $\left(\mathrm{M}^{\oplus}\right)$.

$$
\mathrm{C}_{23} \mathrm{H}_{25} \mathrm{NO}_{5} \text { (395.4) Ber. C } 69.86 \text { H } 6.37 \text { N } 3.54 \text { Gef. C } 69.72 \mathrm{H} 6.31 \text { N } 3.39
$$

3,4-Dihydropyrano[3,4-b][1]benzpyran-5(IH)-on (38a): Eine Lösung von $0.66 \mathrm{~g}$ (2.5 mmol) $35 \mathrm{c}$ in $20 \mathrm{ml}$ absol. Methanol wurde unter Eiskühlung mit Chlorwasserstoff gesättigt und $2 \mathrm{~h}$ bei $0^{\circ} \mathrm{C}$ gehalten. Dann wurde i. Vak. eingedampft und der Rückstand in Diethylether aufgenommen. Es wurde mit Wasser geschüttelt, getrocknet (Natriumsulfat) und i. Vak. eingeengt. Umkri- 
stallisation aus Methanol lieferte farblose Kristalle mit Schmp. $122-123.5^{\circ} \mathrm{C}$; Ausb. $0.18 \mathrm{~g}$ $(36 \%)$ ) - IR: 2970, 1642,1630,1600 $\mathrm{cm}^{-1}$. $-{ }^{1} \mathrm{H}-\mathrm{NMR}\left(\mathrm{CDCl}_{3}\right): \delta=2.7(\mathrm{tt}, J=5.5,1.5 \mathrm{~Hz}$, $2 \mathrm{H}), 3.97(\mathrm{t}, J=5.5 \mathrm{~Hz}, 2 \mathrm{H}), 4.52(\mathrm{t}, J=1.5 \mathrm{~Hz}, 2 \mathrm{H}), 7.18-7.87(\mathrm{~m}, 3 \mathrm{H}), 8.2(\mathrm{dd}, J=8.5$, $2 \mathrm{~Hz}, 1 \mathrm{H}) .-\mathrm{MS}: m / e=202\left(\mathrm{M}^{\oplus}\right)$.

$$
\mathrm{C}_{12} \mathrm{H}_{10} \mathrm{O}_{3} \text { (202.2) Ber. C } 71.28 \mathrm{H} 4.98 \text { Gef. C } 71.27 \mathrm{H} 4.98
$$

3,4-Dihydro-[1]benzothiopyrano[2,3-clpyran-5(1H)-on (38b): A) Das bei 35d/37 beschriebene Produktgemisch $(1.43 \mathrm{~g})$ wurde in $40 \mathrm{ml}$ absol. Methanol gelöst, die Lösung wurde mit Chlorwasserstoff gesättigt und anschließend $0.5 \mathrm{~h}$ rückfließend erhitzt. Aus der i. Vak. eingeengten und gekühlten Lösung schieden sich farblose Kristalle ab; Ausb. $0.23 \mathrm{~g}$.

B) Herstellung wie vorstehend aus $0.24 \mathrm{~g} \mathrm{(1} \mathrm{mmol)} 37$ (in $30 \mathrm{ml}$ absol. Methanol) bei Raumtemp.: farblose Kristalle mit Schmp. $103^{\circ} \mathrm{C}$, Ausb. $0.12 \mathrm{~g}$ ( $55 \%$, nicht umkristallisiert). - IR: 2920 , $1605,1580 \mathrm{~cm}^{-1}$. - ${ }^{1} \mathrm{H}-\mathrm{NMR}\left(\mathrm{CDCl}_{3}\right): \delta=2.77(\mathrm{tt}, J=5.5,1.5 \mathrm{~Hz}, 2 \mathrm{H}), 4.05(\mathrm{t}, J=5.5 \mathrm{~Hz}$, $2 \mathrm{H}), 4.53(\mathrm{t}, J=1.5 \mathrm{~Hz}, 2 \mathrm{H}), 7.4-7.67(\mathrm{~m}, 3 \mathrm{H}), 8.38-8.73(\mathrm{~m}, 1 \mathrm{H}) .-\mathrm{MS}: m / e=218$ $\left(\mathrm{M}^{\oplus}\right)$.

$$
\mathrm{C}_{12} \mathrm{H}_{10} \mathrm{~N}_{2} \mathrm{~S}(218.3) \text { Ber. C } 66.03 \mathrm{H} 4.62 \mathrm{~S} 14.69 \text { Gef. C } 66.18 \mathrm{H} 4.63 \mathrm{~S} 14.68
$$

3,4-Dihydro-1H-pyrano[3,4-b]chinolin-5(10H)-on (38c): Zu einer siedenden Lösung von $0.88 \mathrm{~g}$

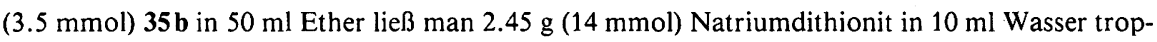
fen. Nach 1stdg. Rückflußerhitzen ließ man Erkalten. Der nach Eindampfen erhaltene Feststoff wurde dreimal mit einer siedenden Essigester/Ethanol-Mischung (1:1) extrahiert. Nach Einengen der Extrakte und Umkristallisation aus Methanol entstanden farblose Kristalle mit Schmp.

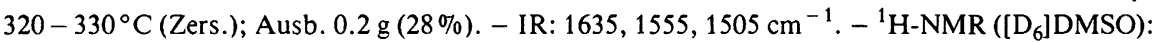
$\delta=2.3-2.7\left(2 \mathrm{H}\right.$, Spinmultiplizität wegen Überlagerung mit $\left[\mathrm{D}_{6}\right] \mathrm{DMSO}-$ Signal nicht festzustellen), 3.9 (t, $J=5.5 \mathrm{~Hz}, 2 \mathrm{H}), 4.57(\mathrm{~s}, 2 \mathrm{H}), 7.0-7.8(\mathrm{~m}, 3 \mathrm{H}), 8.07(\mathrm{~d}, J=8 \mathrm{~Hz}, 1 \mathrm{H}), 11.48$ $\left(1 \mathrm{H}, \mathrm{D}_{2} \mathrm{O}\right.$-Austausch). - MS: $m / e=201\left(\mathrm{M}^{\oplus}\right)$.

$$
\mathrm{C}_{12} \mathrm{H}_{11} \mathrm{NO}_{2}(201.2) \text { Ber. C } 71.63 \text { H } 5.51 \text { N } 6.96 \text { Gef. C } 70.90 \text { H } 5.59 \text { N } 6.99
$$

1) 99. Mitteilung: F. Eiden und G. Felbermeir, Arch. Pharm. (Weinheim, Ger.), im Druck.

2) J. Gore und F. Guigner, Bull. Soc. Chim. Fr. 1970, 3521; G. Zweifel und J. Plamondon, J. Org. Chem. 35, 898 (1970); F. Eiden und K. Th. Wanner, Arch. Pharm. (Weinheim, Ger.), im Druck.

3) U. Petersen und H. Heitzer, Liebigs Ann. Chem. 1976, 1659.

4) $F$. Eiden und $H$. Haverland, Naturwissenschaften 52, 513 (1965); F. Eiden, Chimia 23, 49 (1969).

5) K. Kavase und K. Sakashika, Bull. Chem. Soc. Jpn. 35, 1869 (1962).

6) A. G. Cook, Enamines: Synthesis, Structure and Reactions, Marcel Decker Inc., New York 1969; F. Eiden und $K$. Th. Wanner, Arch. Pharm. (Weinheim, Ger.), im Druck.

7) Diese Ergebnisse stimmen nicht mit Angaben von J. A. Hirsch und $X$. L. Wang, Synth. Commun. 12, 333 (1982) überein, wonach 3 mit $19 \mathrm{~d}$ in einer "standard procedure" ausschließlich $15 \mathrm{~d}$ bilden soll.

8) Über Reaktionen von Enaminen mit Disulfiden siehe auch: G. Liso, P. Marchini und A. Reho, Phosphorus Sulfur 2, 117 (1976); M. E. Kuehne, J. Org. Chem. 28, 2124 (1963).

9) H. O. House, L. J. Czuba, M. Gall und H. D. Oswald, J. Org. Chem. 34, 2324 (1969).

10) Nach J. A. Hirsch und $X$. L. Wang, Synth. Commun. 12, 333 (1982), soll 18 das thermodynamisch stabilere Isomer sein; es wurde von den Autoren aus einem 16/18-Gemisch chromatographisch abgetrennt.

11) J. K. Rasmussen, Synthesis 1977, 91.

12) G. Stork und P. F. Hudrlik, J. Am. Chem. Soc. 90, 4464 (1968). 